施工

\title{
STUDY ON THE DESIGN OF EARTHMOVING BY BULLDOZER
}

\author{
(Trans. of JSCE, October 1953)
}

\author{
Yasuo Itami, C.E. Member
}

\begin{abstract}
Synopsis In this paper, author presents the production and cost computation which are said to be the main point in the design of earthmoving works executing by bulldozer. Theoretical consideration on design has been executed in order to make clear the every problem, especially those hitherto no clear and unknown, and by putting the records on earthmoving works in order, it was successful to obtain several factors and coefficients which are neccessary for the computations, consequently those computations have been led up to the level of practical use.
\end{abstract}

To caluculate the quantity of earth work, author introdiced a practical formula, in which a field-work coefficient is used, and this propose formula, makes the calculation of the quantity of earth work much simpler than the conventional method. Moreover, if the field-work coefficients, which the author has obtained by classifying the degree of easiness of work according to the kind of work, are used, the discrepancy between the estimated work efficiency and the actual work efficiency can be minimized. This is the important point of the present study.

In computing the work cost, a concrete calculation of various costs such as repair cost, residual value, depreciation cost, etc. has been made possible by extending the theory of depreciation which states that the sum of the depreciation and repair costs is constant, to the conditions of various kinds. The problems regarding the method of computation of the rental which is subject to the fluctation of commodity prices, or the administration expenses, have been also solved.

Further, the author obtained, through actual experiment, various coefficients neccessary for computing the rentals and especially the economical life of various types of bulldozer and the ratio of the maintenance and repair expenses to the purchasing expenses, and made it possible to calculate the practical value such as the rental for the bulldozers which are now in use in Japan. In addition, the author has shown a few examples of computation.

On estimation of repair costs, author established a method of calculating repair costs, taking into consideration the time and number of the periodical overhauls of machine, and succeed in obtaining on correct estimation of the repair expenses, because he was able to for each type.

Regarding the calculation of operating costs, the author collected and classified many deta concerning the per hour consumption of the main fuel and lubricant oils, and was able to fine out the increase and decrease of consumption, which vary with the change of the work condition. At the end of this paper, the author added tables and graphs with hourly quantity of earth work and unit costs by the type of bulldozer, according as the easiness of the work and carrying distances.

要 旨 本研究はブルドーザによる土工の設計に拉いて，その主軸とされる土工量の算定括よび工費の 算定に関するものである。設計関する各項目についての指針を示すことほるちろんであるが，従来より 要望されていたが不明確であり未知であつた多くの問題について理論的解明を行い，またこれらの実績沉 関する諸資科を整理して，算定に必要な諸係数を求めることに成功し，との結果これらの算定を作業条件 とブルドーザの各型式の種別に従つて，実用的に実施できる段階に導いたすのである。

土工量の算定に括いては，土工量の実用的な算定公式を考案し，卡の公式子用万ると，作業条件の変化 にともなう土工量の算定が従来より簡単であり，著者が工種別に作業の難易性を分類して求めた現場作業 係数を用うることにより,設計と実施とに拈ける作業能率の誤差を少くできることが研究の要点となつて いる。をたこれの計算を单時間に簡便に行うための計算尺の考案も実現した。

工費の算定においてほ，償却費と修理費を加えた費用が常に一定である償却理論を各種の条件にまで発 展させ，時間当り修理費，残存価格，償却費等の算定についての具体的な計算学可能とした。また物価の 変動をともなう場合の使用科衫よび中古機械の使用料の算定法，あるい々使用料々関係する管理経費の問 題等について解明した。さらに使用料算定に必要な諸係数, 特に各型式のブルドーザの経济的耐用時間と 維持修理費の購入経費に対する割合いについて実験的に求め, 現在わが国で使用されているブルドーザに ついての使用料等の実用值を計算することを可能とし，また計算例もいくつか示した。

次に修理費の見積りについても, 初めて定期的全分解整借の時期括よび回数を考慮沉入れた計算法を確 立し，各型式に対する修理率を実験的に求めることができたので，修理費の見積りを正しく求めることに 成功した。

運軾経費の算定に稀いても，時間当りの主然料，油脂等の消費実績等について，多くの資料を整理し， 作業条件の変化に応ずる消費量の増減を知ることができる。

最後にブルドーザの型式別に現場作業の難易性と，土運搬距離に応じた時間当り土工量と土工单価の表 並びにグラフを作成してブルドーザによる土工に関する見積りを一層便利ならしめた。 


\section{ブルドーザによる土工の設計に関する研究}

正員伊丹康 夫*

目

第 1 章 総

論

1.1. 緒

論 3

1.2. ブルドーザによる土工の設計 3

1.2.1. 設計反和ける特異性……………....

1.2.2. 設計に和ける問題点…................... 3

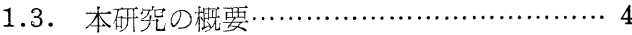

第 2 章 土工量の算定

2.1. 概 説

6

2.2. 土工量の実用算定公式.

2.2.1. 実用算定公式の理論

2.2.2. ブレード（排土板）面積 $B$

2.2.3. 土運搬距離 $D$

2.2.4. 現場作業係数 $F$

2.2.5. 土量換算係数 $f$

2.3. 各種ブルドーザによる土工量の算定………11

2.3.1. ブルドーザ土工作業計算尺について $\cdots 11$

2.3.2. 土工量の計算実例………..............11

2.3.3. 土工量の算定上考慮を要する問題……13 第 3 章 使用料等の算定

3.1. 概 13

3.2. 購入費, 修理費, 使用料, 残存価格, 償却費等の基本的関係执よびこれらの

算定式. 14

3.2.1. 購入費，修理費䍕計执よび経済的 耐用時間の関係. 14

3.2 .2 . 時間当り修理費 $r(x) \quad \cdots \cdots \cdots \cdots \cdots \cdots \cdots \cdots \cdots \cdots$

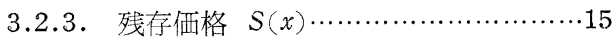

3.2.4. 償却費累計 $D(x) \cdots \cdots \cdots \cdots \cdots \cdots \cdots \cdots \cdots \cdots \cdots \cdots \cdots$

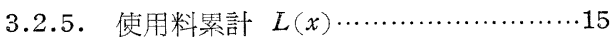

3.2.6. 時間当り使用料 $l(x) \cdots \cdots \cdots \cdots \cdots \cdots \cdots \cdots \cdots \cdots$

3.3. 修理費の及物価指数の変動を考慮した 場合の使用料の算定…………………16

3.3.1. 修理費, 経済的耐用時間等の基本 的関係. .16

3.3.2. 使用料累計. .17

3.3.3. 時問当り使用料 18

3.4. 購入価格を評価替した場合の使用料の 算定.

3.4.1. 修理費, 経済的而用時間等の基本 的関係 19

3.4.2. 使用料累計
次

3.4.3. 時間当り使用料… 21

3.5. 付古機械の使用料の算定………...........22

3.6. 便用料の算定公式(管理費を含めた場合) $\cdots 22$ 3.6.1. 年間標準使用料算定公式…………...22

3.6.2. 時間当り使用料算定公式……………24

第 4 章 ブルドーザの使用料等の算定 そ必要な使用奏績および使用 料等の計算実例

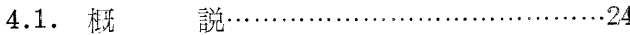

4.2. 運転時間の奏績……………............2 25

4.3. 定期整備の実績………………........26

4.4. X抢よび $f$ の值………….................2. 27

4.4.1. A.G.C.A. の資料……...............2.

4.4.2. 国産ブルドーザについての值……....27

4.4.3. キャタピラー D-8 についての值……29

4.5. 管理費その他………………..............29

4.5.1. 管 理 費……….....................29

4.5.2. スクラップの価格………............3

4.5.3. 物価の变動経過………................3 30

4.6. 使用料の計算….............................30

4.6.1. 基本式炕々る場合………………3 30

4.6.2. 修理費の物洒変動を考光た場合………31

4.6.3. 購入価格を評価替した場合………....32

4.6.4. 同一型式で購入年度の異る場合の

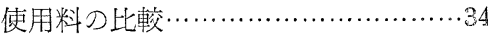

4.7. 修理費の計算…………....................

4.7.3. 修理費率…….........................35

4.7.2. 修理費の見積計算…………….....37

第 5 章 工費稆よび工期の算定

5.1. 概 説…….........................40

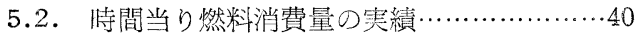

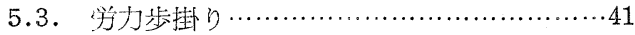

5.4. 工費の算定……….......................4.

5.4.1. 運転時間に比例乙て増減する経費……41

5.4.2. 固定的な経費（運転時間比無関係

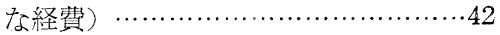

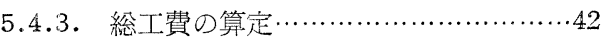

5.5. 七期の算定………………….......4.

5.6. ブルドーザ土工と人力トロ運搬土工と の比較. .42

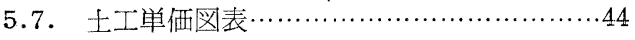




\section{第 1 章 総論}

\section{1. 緒論}

ブルドーザは機械化土工に最も厇範囲に利用できる建設機械である。すなわち掘削, 土運搬, 撒土, 盛土, 転圧 括よび仕上げの作業をブルドーザのみで行うことができるので土工に単独で使用されることも，また他の建設機械 飞組合せて使用されることるできる。

ブルドーザほ前記の作業の他, 除根，伐木，凍土括よび硬土等の破碎等の特殊作業を行い，またスクレーパ， ルータ, タンピングローラ等の率引操作の原動機械として使用されるので, 整地, 道路土工, 河川の築湜掠よび 㻕削工事，ダム工事等にほ欠くことのできない機械でめる。

履带式 (crawler type) のブルドーザは主として数十米以内の近距離の土運搬を伴う土工に最も適する。

ブドーザは米国执いて始めて 1915 年裴作され第 2 次世界大戦中の飛行場の急速設定に威力を発揮したこと 恃有名である。わが国に执いては戦争中，陸海軍で主として飛行場設定のために米軍のるのを模倣して製作を始 めたこともあつたが，注とんど実用に洪し得なかつた。戦後注米軍より多数のブルドーザの払下げを受けたの で，その使用法を体得し，その徫大な作業力を知る機会を得た。

土工々事にブルドーザを本格的に使用せんとする気運は，戦後，国産ブルドーザの試作機が完成して間もない 炤和 24,25 年頃から起り始めた。しかしその頃は，わが国としてはブルドーザによる施工法はまつたく経験がな くこのような機械化工事には幾度となく失敗を重ね，工事る計画通り進捗しないのが常道であつたので，現場に あまり好感をるつて受入れられないととも多かつた。

その後, 機械の性能が向上すると徒い，各方面に怙けるブルドーザ施工の苦い経験す次第飞実を結び，乙れと 併行して技術者の訓育，オペレータの養成㲸も努力が払われかつ機械の運営招よび管理について子要領がのみこ めてきたので，次第にブルドーザが土工々事で万能的な，能率的な威力を発揮することができるようになり，現 在では土工々事用機械として広く普及し，わが国での保有台数約 3,000 台を数觉るに至つた。

しかし，ブルドーザによる土工及事の計画のたてかた，設計の組みかたが，從来の人力またね「トロ」の方式に よる土工々事と，性格的に異なり，また施工扔よび機械の運営管理に捻いては，専門的知識と経験を必要とする ため現在でも正しい計画，設計㧠よび見積のもとで，ブルドーザを高率的と使つて工事を施工している処は比較 的少いとい壳る。その原因の第 1 としては，従来の方式の土工々事では作業能力すなわち，1時間当りの土工量

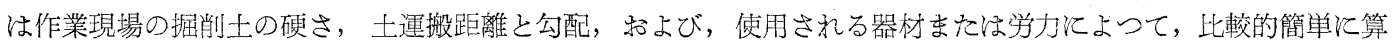
出されるが，ブルドーザ土工方式ではとの作業能力が上記の条件以外に機械の性能拈よび土の物理的性質に大き く影響されることが多く，従つて比較的含水比の高いわが国で怔米国の資料をそのまま使用できないことである。 原因の第 2 としては土費の大きな部分を占める，機械償却費の適正な算定方法が確立されて呿らず， 充た維持修 理費の実績の整理がなされていないため，工費走正しく見積るととに大きな欠㫟があり，各所まちまちの工費が 見積られているのが現況である。

本研究は以下これらの問題に対し 設計上の見地より理論的解説を試みるとともに各種の現場実績を整理し, 特 飞設計上の重要なる問題点を解決することにより，ブルドーザ土工に対する具体的な設計基準 並び方法をあた えるものである。これにより，ブルドーザ以外の重機械とよる工事の設計とる，この研究の成果を応用すること ができる。

\section{2. ブルドーザによる土エの設計}

\subsection{1. 設計における特異性}

従来のほとえぞの土工，たと兄ば人力掘削，ト口運般の土工あるいはラダー掘削機と機関車の組合せ飞よる掘 削土運搬工事等，あらゆる土工の設計注いて単位土工量当りの単価表を算出することは多年の経験沈よるこ

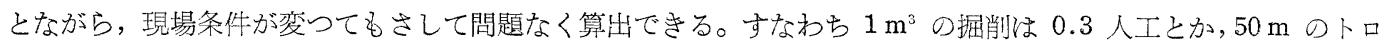
運般は $1 \mathrm{~m}^{3}$ そつき 0.2 人工とか, あるいは 1 時間 $120 \mathrm{~m}^{3}$ 掘りラダー掘削機により掘削し $20 \mathrm{t}$ 蒸気機関車飞よ

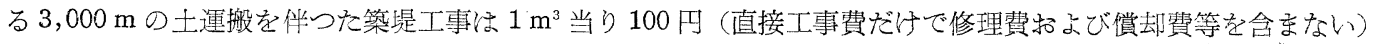
であるというように，設計の見積りは $1 \mathrm{~m}^{3}$ または $100 \mathrm{~m}^{3}$ 当り単価表が使用されるのが慣例であつた。これら従 来の土工の設計が $1 \mathrm{~m}^{3}$ 采たは $100 \mathrm{~m}^{3}$ 当りの単価表を用いていることは, その第 1 が人力が主力となつて工事が なされて括り，機械を使用した場合も運転手の他に多数の人夫を必要とし，概して1日の実作業時間が一定して 
いることと，第 2 が現場条件が変つても，同一地域では $1 \mathrm{~m}^{3}$ 当り単価には単純で判定し易い影響しか招よぼさな いためである。

一方ブルドーザとよる土工は機械が主力として添とえどの一貫した作業が施工され，機械の型式の種別と運転 距離の長短により，単位時間当りの土工量が大きく変化する。また最も顕著なととは掘り取られる土砂招よび走 行路艋を形成する土砂の物理的性質により作業効率が大きく影響することは，従来の土工㹸られなかつたこと である。すなわち関東地方のローム質土でね，瀬戸内海沿岸の砂覧土より作業が極めて困難で年間の作業可能日

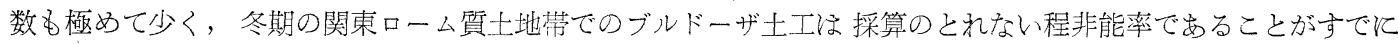

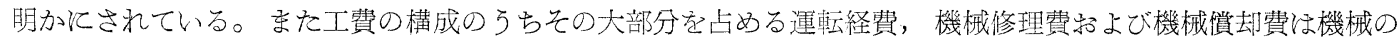
実働時間比例して掛る性格のものであるから，時間当り単価表の作製を省略して直ちに $100 \mathrm{~m}^{3}$ 当りの単価表を 他の類似の工事実績等により作成すること々設計に 誤算を生ずる原因となつてくる。事実わが国でブルドーザ土 工を始めた頃は，実働時間当りの土工量も正しく判定ずるとができないのに，ずでて従来の土工の設計に括け る場合と同様飞, $100 \mathrm{~m}^{3}$ 当りの所要時間を算定して, 次に $100 \mathrm{~m}^{3}$ 当り燃料, 労力等の所要量を算定し, その結 果から $100 \mathrm{~m}^{3}$ 当りの単価を算定していた。この方法で泳とんど工事の進捗が計画通り行われず，工費も大幅 に，誤差を生ずることが少なくなかつた。

またこの種の新しい重土工機械とついて共通なことであるが，機械の型式の別，機械経歴の別辌よび機械の運 営管理の良否により修理費のかかり方も異なり，而用時間数も違 らために，償却費が異なりまた工程の大切な 要素である稼働率もこれらにより影響されるので，工事単価の計算は甚だ複雑となる。

従つて現在わが国に和いてブルドーザとよる土工の設計のうち，特に信頼のるてる工期 特よび工費を算定する ことを可能とするためには，ぞうしても工事の立場からしたブルドーザの性能に対する諸研究掠よび工事の実績 についての分析検討を行い，土工量の算定方式と工費の算定方式等况確立することが極めて必要である。

\subsection{2. 設計における間題点}

ブルドーザ土工の設計に括いてほ，時間当りの土工量と時間当りの経費を別個に算定し，これにより単位土工 量当りの工費いわりる単洒を算定するととの必要性を前項に述べた。

先づ第 1 の時間当りの土工量の算定とついて々，作業に使用する機械が定められ，作業条件が与兄られたら， あと作業の難易性を定めるととそより算定怡可能である。米国の USE OF ROAD AND AIRDRONE CON. STRUCTION EQUIPMENT には，この作業の難易性すなわち，ブルドーザの作業郊率 (dozer efficiency factor) の説明が次のと挌り記述されている。

The dozer efficiency factor takes into account the fact that a full 60-minutes work hour is rarely obtained. Efficiency varies depending on supervision, operators, maintenance requirements, and site conditions.

この作業の難易性を設計上ぞう扱うかということは，作業能率算定の上から最も大切で，から難しい問題であ り，従来の土工方式に括いてもとれを分析して基準が得られた例はない。ブルドーザ土工掠いては特にこの問 題浪つての研究が設計並びに施工上重要でめる。

第 2 の時間当り経費の算定についてはとの構成要素として運転費，維持修理費，扔よび償却費の算定が問題と してとり上げられる。先づ, 運転費は運転 1 時間で消費する燃料, 油脂費抢よび労力費の合計である。これは機 械の型式により，核定つた費用として算定ほ比較的容易である。次濰持修理費々奏績を重じて算定すべきで あるが，ブルドーザは運転時間が増加する程，時間当り修理費が増加する具体的な実態をブルドーザの型式ごと にどら八握するか，屯たとの計算はどうず゙きかが新しい問題である。最後の問題は経費のうち最も多額を占め るであるら償却費とついての計算法である。これとは税法上の固定資産の償却法としての定額法 招よび定率质減: 法があるが，いづれも残存価値の実態に合致していない。ブルドーザのような損粁の激しい機械についてはその 寿命は年数で数觉るのでなく，時間数をもつて数えるべきであり，従つて時間当り償却費をどう算定すべきかが. 大きな課題である。

な扔上述の時間当り経費の算定法については 新しい重機械に対して共通の問題として解決されるべき問題であ, る。

\section{3. 本研究の概 要}

本研究はブルドーザ土エの設計に䄧いてとの骨幹をなす土工量の算定, および工費の算定に必要な理論並びに 諸資料を整備し，実用に供し得るなでにこれらの解明を試みたすのである。 
土工量の算定に招いては実用的な算定公式を考案し，その公式に括ける作業の難易性の判定要素として，工事 奏績を分析分類して求めた現場作業係数を用いることを試みたととが研究の重点となつている。

工費の算定に括いてほ，徒来より最も実用性が至しく算定が困難でめつた機械の使用料の理論を実際的な面ま

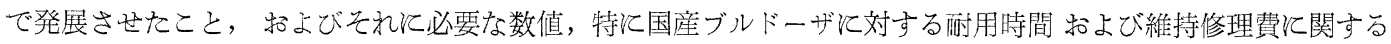
諸係数を多くの実績を整理した結果より求め得たことである。な扮使用料算定上必要な場合が起る物価の変動等 に関する算定式を求め, あるい绽定期整備の時期和よび回数を考慮した修理費等の見積計算に 関する実際的な運 用法を明らか㲸した。

更に工費の算定について重要な要素である運転経費について, 多くの実績を整理し, 作業条件の変化に応じて, 算定に使用できるようと諸要素を分類しその基準を得た。

最後にブルドーザの 型式別涀場作業の難易性と，土運般距離に応じた土工単佂表並びにグラフを作成した。 本研究の内容については既に関連事項を発表して招り，それらの交献を次に参考までに記す。

\begin{tabular}{|c|c|c|c|c|}
\hline & 題 & 揭載誌名または発行所 & 年 & 月 \\
\hline 1 & ブルドーザ土工作業の赛用算定公式 & 建設の機械化 No.43 & 28. & 9 \\
\hline 2 & (補㹂) & 同 上 No.45 & 28. & 11 \\
\hline 3 & ブルドーザ土工設計々算法 & No. 50 & 29. & 4 \\
\hline 4 & 実績を基にしたブルドーザ土工設計々算法 & 建設省直轄工事第 8 回技術研究会 & 29. & 8 \\
\hline 5 & $\begin{array}{l}\text { 建設省の実績より見た国産ブルドーザの水準（運転時間と整備費の実態 } \\
\text { につて }\end{array}$ & 建設の機械化 No.57 & 29. & 11 \\
\hline 6 & $\begin{array}{l}\text { 建設省の実績より見た国産ブルドーザの水準（国産ブルドーザと米国製 } \\
\text { 芒ルトーザの比較） }\end{array}$ & 建設の機械化 No.58 & 29. & 12 \\
\hline 7 & 建設機械の使用料の算定法並びにブルドーザによる使用料算定の実例 & $\begin{array}{l}\text { 日本建設機械化協会 } \\
\text { 昭和 } 30 \text { 年技術講演会 }\end{array}$ & 30. & 4 \\
\hline 8 & ブルドーザ士工の設計および施工 & 技報堂全書 & 30. & 11 \\
\hline 9 & プルドーザ土工作業計算尺 & 特許出願 昭 28-24209 & & \\
\hline
\end{tabular}

な抒本研究の対象として使用されたブルドーザの型式は 表一1.1 ととの作業要目を示す。これらほわが国でも つとも多く土工々事使用されているものである。

表一1.1 ブルドーザ作業要目一覧表

\begin{tabular}{|c|c|c|c|c|c|c|c|c|c|c|}
\hline & & \multicolumn{3}{|l|}{ 小 } & \multicolumn{2}{|l|}{ 三 } & \multicolumn{2}{|l|}{ 日 } & \multicolumn{2}{|c|}{ キャ夕ビラー } \\
\hline & & $D-50$ & $D-80$ & $\mathrm{D}-120$ & B B IV & $\mathrm{B} F$ & NTK-4 & NTK-7 & $D-7$ & $\mathrm{D}-8$ \\
\hline 全 長 (単 車) & $(\mathrm{mm})$ & 3,475 & 4,325 & 4,982 & 3,720 & 4,350 & 3,100 & 4,000 & 4,130 & 4,650 \\
\hline (排土板付き) & $"$ & 4,455 & 5,430 & 6,100 & 4,690 & 5,470 & 3,830 & 5,330 & 5,350 & 5,970 \\
\hline 全幅 (単 車) & $"$ & 2,045 & 2,560 & 2,580 & 2,160 & 2,460 & 1,980 & 2,500 & 2,460 & 2,620 \\
\hline (排土板付き) & $"$ & 3,000 & 3,850 & 4,100 & 3,500 & 3,860 & 2,890 & 8,360 & 3,860 & 4,040 \\
\hline 全 高（排気管先端） & " & 2,400 & 2,650 & 2,700 & 2,700 & 2,860 & 1.730 & 2,170 & 2,030 & 2,290 \\
\hline 整備重量（単 車） & $(\mathrm{kg})$ & 7,000 & 13,900 & 16,000 & 10,000 & 15,000 & 4,600 & 11,500 & 11,200 & 15,600 \\
\hline (排土板付芯) & $"$ & 9,000 & 16,000 & 20,500 & - & 16,000 & 6,200 & 13,500 & - & - \\
\hline \multirow{2}{*}{$\begin{array}{l}\text { 軌 板 幅 } \\
\text { 無限軌道中心距離 }\end{array}$} & $(\mathrm{mm})$ & 400 & 560 & 580 & 460 & 560 & 330 & 550 & 510 & 560 \\
\hline & $"$ & 1,600 & 2,000 & 2,000 & 1,640 & 1,900 & 1,520 & 2,000 & 1,880 & 2,130 \\
\hline \multirow{2}{*}{\multicolumn{2}{|c|}{$\begin{array}{c}\text { 接 地 圧 (単 車) } \\
\text { (排土板付寻) }\end{array}$}} & 0.42 & 0.44 & 0.51 & - & - & 0.40 & 0.50 & 0.46 & 0.56 \\
\hline & & 0.53 & 0.57 & 0.62 & 0.53 & 0.57 & 0.55 & 0.59 & - & - \\
\hline 主機 & $(\mathrm{P})$ & 55 & 100 & 150 & 80 & 100 & 46 & 85 & $105 \mathrm{P}$ & $185 \mathrm{HP}$ \\
\hline \multicolumn{2}{|c|}{ 排土板大きさ (高さ×幅) $\left(\mathrm{mm}^{2}\right)$} & $750 \times 3,000$ & $1,020 \times 3,8501$ & $1,000 \times 4,100$ & $900 \times 3,500$ & $950 \times 3,860$ & $700 \times 2,890$ & $900 \times 3,860$ & $983 \times 3,860$ & $983 \times 4,060$ \\
\hline \multicolumn{2}{|c|}{ 登 坂 能 力 （単車無牽引） } & $30^{\circ}$ & $30^{\circ}$ & $30^{\circ}$ & $35^{\circ}$ & $35^{\circ}$ & $30^{\circ}$ & $30^{\circ}$ & - & - \\
\hline 最 大蒂 引力 & (kg) & 6,400 & 13,300 & 14,200 & 10,000 & 15,400 & 5,000 & 10,700 & $90 \mathrm{P}$ & $150 \mathrm{P}$ \\
\hline \multirow{7}{*}{ 前進速度 } & $(\mathrm{km} / \mathrm{h})$ & - & 1.84 & - & - & - & - & - & - & - \\
\hline & $"$ & 2.12 & 2.64 & 2.76 & 2.20 & 1.80 & 2.70 & 2.10 & 2.25 & 3.05 \\
\hline & $"$ & 3.26 & 3.66 & 3.70 & 3.40 & 2.50 & 3.70 & 3.40 & 3.54 & 4.35 \\
\hline & $"$ & 6.30 & 5.85 & 4.95 & 6.20 & 3.70 & 4.71 & 5.80 & 5.15 & 5.62 \\
\hline & " & 10.10 & 7.30 & 6.13 & 9.50 & 5.50 & 5.89 & 8.60 & 7.40 & 7.23 \\
\hline & $"$ & -- & 9.60 & 7.78 & - & 7.70 & 8.58 & - & 9.64 & 9.30 \\
\hline & $"$ & - & - & - & - & 9.50 & - & - & - & - \\
\hline \multirow[t]{4}{*}{ 後退速度 } & $"$ & 2.73 & 2.34 & 3.34 & 2.50 & 2.30 & 3.13 & 2.80 & 2.58 & 3.05 \\
\hline & $"$ & 5.19 & 3.32 & 4.46 & 4.00 & 3.10 & - & 5.00 & 4.18 & 4.35 \\
\hline & " & - & 4.63 & 5.95 & 7.30 & 4.60 & - & - & 6.12 & 9.30 \\
\hline & $"$ & - & 7.36 & - & 11.10 & 6.90 & - & - & 8.70 & - \\
\hline
\end{tabular}




\section{第2 章土工量の算定}

\section{1. 概 説}

ブルドーザによる土工量の算定には特に現場の作業の難易性の扱い方を知らねばなら格しかし作業の難易性 ほ定性的な分析は可能であつても，定量的には不可能であるので，著者はこれを作業実績から求めることとし， 特に土工の工種および士質の状態等から士工の難易性の分類を試みた。この際従来の土工量の算定式ではその算 定が繁雑でかつ正確性を欠くので新らしく土工量の奏用算定公式を将案した。またこれの算定を容易にするため にブルドーザ土工作業計算尺を新案した。

なお以上の算定方法によつて，機械の各型式，各種現場条件応ずる土工量の算定值を求めた。

\section{2. 土工量の実用算定公式}

\subsection{1. 実用算定公式の理論}

從来ブルドーザの土工量を理論的に算定する場合は次式が使用される。

$$
\begin{aligned}
& \text { 土工量 }=\frac{Q \times f \times 60 \times E}{C_{m}} \quad\left(\mathrm{~m}^{3} / \mathrm{h}\right) \ldots \ldots \ldots \\
& Q: \text { ボーウル (排士板) 容量 }\left(\mathrm{m}^{3}\right) \\
& f: \text { 土量換算係数 } \\
& E: \text { ブルドーザの作業効率 } \\
& C_{m}: \text { サイクルタイム }(\mathrm{min})
\end{aligned}
$$

この式に衫いては，使用ブルドーザの型式によりボーウル容量 $Q$ の值を定め, 土運搬距離拉よび作業現場の土 質等の現場作業条件等から, 土量換算係数 $f$ 执よびブルドーザの作業効率 $E$ の値を定めて土工量を算定する。乙 かし先の場合，各数值の決め方が難かしい。すなわちわが国に括いては土質が粘土分に富み，含水比が高く，ブ ルドーザ土工に非能率な工事現場が数多く，従つて作業能率が現場の諸条件により大きな差簧を生ずるから，E の值の示す範囲は大きくなり，その判定は特に難かしい。

またサイクルタイム $C_{m}$ の值は，日々の現場条件の変化，作業状沿の変化により絶えず変化するため，同一工事 であつても常に一定の值ととることができず，まる仮定のもとで $C_{m}$ の平均值を想定して計算しても実作業に適

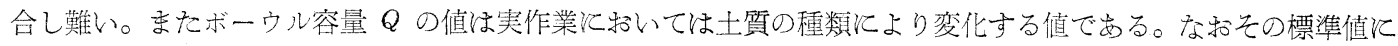
ついては各所各人未ち委らである。(表一 2.1 参照)

以上のと礼りこの理論算定式は，実際に当つてほ使用が不便であるので，これに代る算式定として作業現場を 見聞すれば簡笚に算定できる実用性の岕る算定式が強く要望されていた。私は多くの工事夷績の分析検討の結果， 次に示す夷用算定公式を考案した。この実用算定公式は前述の理論算定式と関連性をもつてほいるが，理論算定

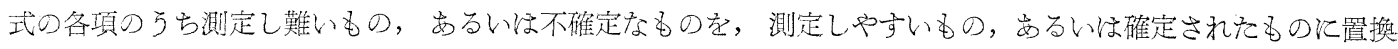
乙, 特に従来の作業効率 (efficiency factor) を現場の綜合的な作業の難易度㲸基いて定められる現場作業係数 (field condition factor) 飞变えたことである。

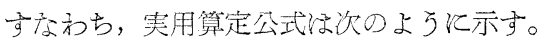

$$
\begin{aligned}
\text { 土工量 } & =\frac{10 \times\left(B \times f \times 60^{2} \times F\right)}{16 \times(3 D+20)} \\
B: & \text { ブレード面積 }\left(\mathrm{m}^{2}\right) \\
D: & \text { 土運搬距離 }(\mathrm{m}) \\
F: & \text { 現場作業係数 } \\
f: & \text { 土量換算係数 }
\end{aligned}
$$$$
\left(\mathrm{m}^{3} / \mathrm{h}\right)
$$

以上の実用算定公式においては，理論的算定式のボーウル容量 $Q$ をブレード面積 $B$ に, すなわち $Q=B \times 10 / 16$ の関係，サイクルタイム $C_{m}$ を土運搬距離 $D$ 亿，すなわち $C_{m}=(3 D+20) / 60$ の関係を用いて実用算定公式を得 た。従つて $Q$ 托よび $C_{m}$ がBおよびDにおきかえられたため，それらの数值の決定々極めて容易になつた。現場 作業係数 $F$ は理論的算定式に新ける作業効率 $E$ より現場条件が更に広範に加えられたるのであり，作業の難易性 を示す係数で努る。

（注）奥野正和氏虫この寒用算定公式について，「土木技術」第10巻，第6 号に次のごとく批評を寄せている。 
してある。非常に䒠用度の高い公式である。

伊丹氏の公式の使用に当つて，一番重要なのは，現場作業係数の決定であるが，私の勤務先で過去 1 年間に実施した数十件の工事の5ち， ドーザの使用延台数が多く，かつ現場作業条件の比較的明らかである約 10 件の工事記録について検討した結果では，伊丹氏の示された現場 作業係数は妥当なるのであると認められる。私の調查では同一現場で衝いたドーザを機種 (D-7, D-80, BF, D-120) 毎に別にわけ，更に 1台每のドーザについて作業土工の実績から逆算して現場作業係数を求めて見ると，ほとんど一定の值が得られ，から伊丹氏の示した係数，

数值が正しいことがわからた。

次に実用算定公式の成立した経過並びそ式中の各項について説明する。

\subsection{2. ブレード（排土板）面皘 B}

従来のボーウル容量 $Q$ そついては表一2.1の資料を作成することができるが，これは設計者によりまちまちの 値を使用していることがわかる。

表一1.1 そ拉ける型式のブルドーザのボーウル容量の各数値と, ブレード面積との関係を図示すると図一2.1の

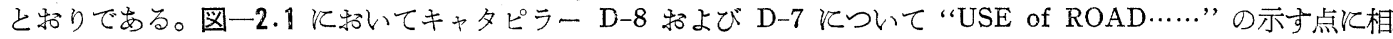
等する点は，私が採用していた点と，ほとんで一致するので記入を省略する。図一2.1のようとボーウル容量とブ レード面積が直線的関係にあるとすると，次の関係式を得る。

$$
Q=B \times \frac{10}{16}
$$

な特この関係式が適用されるのは，ストレートドーザ（進行方向植角のブレード）で，両端に散逸防止用の

\section{表一2.1 ボーウル容量と面皘との関係}

\begin{tabular}{|c|c|c|c|c|c|}
\hline \multirow{2}{*}{ 型 式 } & \multirow{2}{*}{$\begin{array}{c}\text { ブVーF } \\
\text { 寸 } \\
(\mathrm{mm} \times \mathrm{mm})\end{array}$} & \multirow{2}{*}{$\begin{array}{c}\text { ブレート } \\
\text { 面 種 } \\
B\left(\mathrm{~m}^{2}\right)\end{array}$} & \multicolumn{3}{|c|}{ ポーウル容量 $Q\left(\mathrm{~m}^{3}\right)$} \\
\hline & & & $\begin{array}{l}\text { USE OF } \\
\text { ROAD }\end{array}$ & 斎藤義治氏 & 著 者 \\
\hline $\begin{array}{c}\text { キャ多ピラ } \\
\text { D-8 }\end{array}$ & $3400 \times 1142$ & 3.88 & 2.39 & & 2,40 \\
\hline $\mathrm{D}-7$ & $3099 \times 1142$ & 3.54 & 2.18 & 2.50 & 2.20 \\
\hline 三菱日本 B F & $3860 \times 950$ & 3.67 & & 2.40 & 2.20 \\
\hline 小松 D-80 & $3850 \times 1000$ & 3.85 & & 2.40 & 2.00 \\
\hline 三菱昌本 & $3500 \times 900$ & 3.15 & & & \\
\hline 日特 NTK 7 & $\begin{array}{l}\text { アングル } \\
3860 \times 900\end{array}$ & 3.47 & & & \\
\hline 三菱星的本 & $3150 \times 800$ & 2.52 & $\mathrm{D}-6(1.43)$ & 1.70 & 1.20 \\
\hline 小 松 D-50 & $3000 \times 750$ & 2.25 & & 1.60 & 1.10 \\
\hline 日特 NTK 4 & $2890 \times 700$ & 2.03 & & & \\
\hline 小松 D-120 & $4100 \times 1000$ & 4.10 & & & \\
\hline
\end{tabular}

(注) USE OF ROAD ….. USE OF ROAD AND AIRDROME CONSTRUCTION EQUIPMENT の略

\subsection{3. 土運搬距離 $-D$}

従来の理論的算定式のサイクルタイム $C_{m}$ の算定は， 型式によりそれぞれ異なる 前進後退の各変速の種別に従 つて行われる。すなわち

$$
\begin{aligned}
C_{m} & =D\left(\frac{1}{v_{1}}+\frac{1}{v^{2}}\right)+t \quad(\mathrm{~min}) \cdots \cdots \cdots(2.4) \\
D & : \text { 土運搬距離 }(\mathrm{m}) \\
v_{1}: & \text { 前進速度 }(\mathrm{m} / \mathrm{min}) \\
v_{2}: & \text { 後退速度 }(\mathrm{m} / \mathrm{min}) \\
t: & \text { ギキー入替えに要する時間 }(\mathrm{min})
\end{aligned}
$$

(2.4) 式に特いて $1 / v_{1}+1 / v_{2}$ は変速の種類により異なる 項であつて,実際作業に適用される場合について計算する

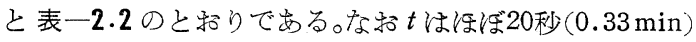
と算定される。表一 2.2 亿示すと招り $1 / v_{1}+1 / v_{2}$ の值の 最す多く起り得る值として 0.050 をとれば (2.4) 式は次 のようになる。

$$
C_{m}=\frac{3 D+20}{60} \quad(\min )
$$

\begin{tabular}{|c|c|c|c|c|c|}
\hline \multirow{2}{*}{ 型 } & \multicolumn{2}{|l|}{ 前 } & \multicolumn{2}{|r|}{ 進 } & \multirow{2}{*}{$\begin{array}{c}1 / v_{1}+1 / v_{2} \\
(\mathrm{~min} / \mathrm{m})\end{array}$} \\
\hline & \begin{tabular}{l|} 
変速 \\
$E^{-}$
\end{tabular} & $\begin{array}{c}v_{1} \\
(\mathrm{~m} / \mathrm{min})\end{array}$ & $\begin{array}{l}\text { 変速 } \\
E^{-}\end{array}$ & $\begin{array}{c}v_{2} \\
(\mathrm{~m} / \mathrm{min}) \\
\end{array}$ & \\
\hline D-7 & $\begin{array}{l}1 \\
1 \\
1\end{array}$ & $\begin{array}{l}34.5 \\
34.5 \\
34.5\end{array}$ & $\begin{array}{l}1 \\
2 \\
3\end{array}$ & $\begin{array}{r}43.3 \\
70.0 \\
101.7\end{array}$ & $\begin{array}{l}0.052 \\
0.043 \\
0.039\end{array}$ \\
\hline $\mathrm{D}-50$ & $\begin{array}{l}1 \\
1\end{array}$ & $\begin{array}{l}32.5 \\
32.5\end{array}$ & $\begin{array}{l}1 \\
2\end{array}$ & $\begin{array}{l}45.3 \\
87.3\end{array}$ & $\begin{array}{l}0.058 \\
0.042\end{array}$ \\
\hline$D-80$ & $\begin{array}{l}1 \\
1 \\
1\end{array}$ & $\begin{array}{l}27.5 \\
27.5 \\
27.5\end{array}$ & $\begin{array}{l}1 \\
2 \\
3\end{array}$ & $\begin{array}{l}39.0 \\
55.3 \\
71.1\end{array}$ & $\begin{array}{l}0.062 \\
0.054 \\
0.049\end{array}$ \\
\hline B B III & $\begin{array}{l}1 \\
1 \\
1\end{array}$ & $\begin{array}{l}28.5 \\
28.5 \\
28.5\end{array}$ & $\begin{array}{l}1 \\
2 \\
3\end{array}$ & $\begin{array}{l}36.7 \\
58.4 \\
93.8\end{array}$ & $\begin{array}{l}0.062 \\
0.052 \\
0.046\end{array}$ \\
\hline B F & $\begin{array}{l}1 \\
1 \\
1 \\
2 \\
2 \\
2 \\
2\end{array}$ & $\begin{array}{l}27.0 \\
27.0 \\
27.0 \\
37.5 \\
37.5 \\
37.5\end{array}$ & $\begin{array}{l}1 \\
2 \\
3 \\
1 \\
2 \\
3\end{array}$ & $\begin{array}{l}38.3 \\
51.7 \\
76.6 \\
38.3 \\
51.7 \\
76.7\end{array}$ & $\begin{array}{l}0.063 \\
0.056 \\
0.050 \\
0.053 \\
0.046 \\
0.040\end{array}$ \\
\hline B B IV & $\begin{array}{l}1 \\
1 \\
2 \\
2\end{array}$ & $\begin{array}{l}33.0 \\
33.0 \\
51.0 \\
51.0\end{array}$ & $\begin{array}{l}1 \\
2 \\
2 \\
3\end{array}$ & $\begin{array}{r}41.7 \\
66.7 \\
66.7 \\
122.0\end{array}$ & $\begin{array}{l}0.054 \\
0.045 \\
0.035 \\
0.028\end{array}$ \\
\hline NTK 7 & $\begin{array}{l}1 \\
1\end{array}$ & $\begin{array}{l}31.5 \\
31.5\end{array}$ & $\begin{array}{l}1 \\
2\end{array}$ & $\begin{array}{l}46.6 \\
83.4\end{array}$ & $\begin{array}{l}0.053 \\
0.044\end{array}$ \\
\hline NTK 4 & 1 & 41.1 & 1 & 79.5 & 0.037 \\
\hline
\end{tabular}
ブレードが特についてないものについてである。また 押土の際に土質の相異により起る土の散逸程度の大小 は後述する現場作業係数の要素に入れて考光る。

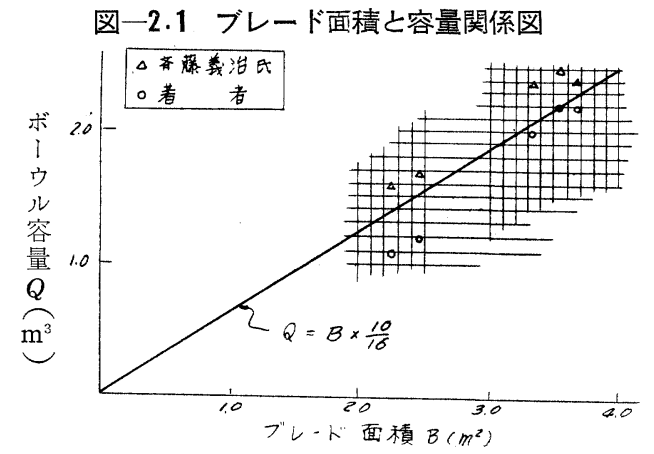

表一2.2 $1 / v_{1}+1 / v_{2}$ の值

備考：前進速度は公称定格速度の $90 \%$ を使用した。 
この場合 (2.4) 式により計算したサイクルタイムと (2.5) 式により計算したサイクルタイムとの間の誤差は土

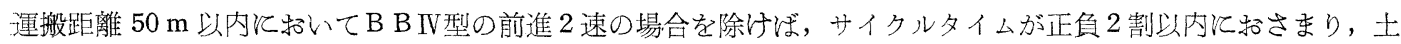
運搬距離がさらに増しても症とんど誤差の増加はない。しかしこの (2.5) 式により求めたサイクルタイムと実作 業に和けるサイクルタイムとの間の誤差については，次項で述べる現場作業係数 $F$ で処理することができる。す なわち高速で土運搬ができる場合は，土質招よび路船も良好で，下り勾配を利用して作業するような走行容易な， すなわち現場作業条件のよい現場であり，反対汇前後進とも低速でしか運行できない場合は，土質怙よび路盤が 不良で走行困難な，すなわち現場作業条件の不良の現場であると考学ることができる。

故にサイクルタイムの項は土運搬距離 $D$ の変数として計算され，標準速度より高速で作業できる現場は 現場作

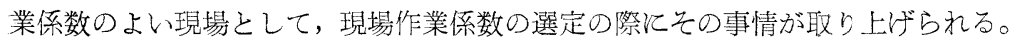

また，タイヤドーザのようとクローラータイプのブルドーザと比較して走行機構が異なり，かつ走行速度が高 速を得られる機械については，(2.5) 式の分子の $(3 D+20)$ を適宜変兄て使用することにより，実用算定公式を 応用して使用することができる。

\subsection{4. 現場作業係数 $F$}

現場作業係数は現場の作業条件の良否を綜合的判定すべきもので，その判定の対象となる要素としてほ，

(1) 削土また沉運搬される土質の良否

(2) 走行路般の良否

（3）施工方法の難易

（4）ボーウルより土の散逸する程度

(5) 天候尤る影響

であるが，これらの要素の個々に判定して現場作業係数を求めること视困難であるので，専ら工事実績を基沉し て実験的に求め，乙れを工事種別に従つて整理し，現場作業係数の:巽択を容易㲸する推定表の作成を試みた。

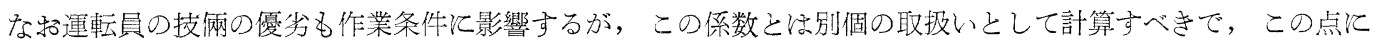
ついては後述 3.3.2. (2) 飞現場実測の結果の 1 例を示す。

\section{(1) 工事実績より得䎲現場作業係数}

過去のブルドーザ土工の実績として建設省，農林省括よび国有鉄道の実績拈よび，著者の関係した建設技術研 宽補助金认よる “建設の機械化施工の経済的規模関する研究” の調查資料のうちブルドーザの作業実績の明確

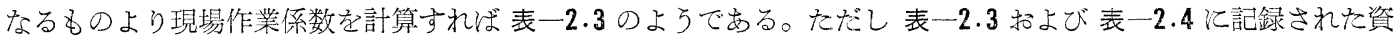
料はとの工事現場での全部すなわち全工事期間の記録でない場合が多いが，結果の判定は施工期間と作業量によ つて検討を加光た。

また私が建設省荒川上流工事々務所に挌いて施工したブルドーザによる河川の掘削工事の実績は 表一2.5のよ

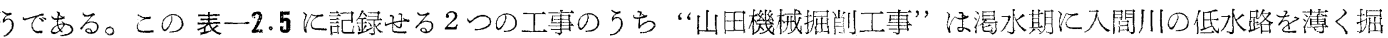
表一 2.3 現 場 実 綪 調 查 資 料 (No. 1)

\begin{tabular}{|c|c|c|c|c|c|c|c|c|c|c|c|c|}
\hline \multirow{2}{*}{ 所 } & \multirow{2}{*}{ 工 事 箇 所 } & \multirow{2}{*}{ 型 式 } & \multirow{2}{*}{$\begin{array}{l}\text { 建設譏榑 } \\
\text { 番 号 }\end{array}$} & \multirow{2}{*}{ 施工年月日 } & \multirow{2}{*}{$\frac{\text { 運土距攡 }}{(\mathrm{m})}$} & \multirow{2}{*}{ 土 } & \multirow{2}{*}{$\begin{array}{l}\text { 稼 働 } \\
\text { 時間率 }\end{array}$} & \multirow{2}{*}{ 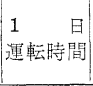 } & \multirow{2}{*}{$\begin{array}{c}\text { 総作業量 } \\
\left(\mathrm{m}^{3}\right)\end{array}$} & \multirow{2}{*}{$\left|\begin{array}{c}1 \text { 時間当 } \\
\text { 作 豪 } \\
\left(\mathrm{m}^{3}\right)\end{array}\right|$} & \multicolumn{2}{|c|}{ 現場作業係数 } \\
\hline & & & & & & & & & & & 数 值 & 平均値 \\
\hline \multirow[t]{6}{*}{ 建設省関係 } & \multirow{3}{*}{\begin{tabular}{|} 
帮河川大場堤防災 \\
害復旧
\end{tabular}} & \multirow[t]{2}{*}{$D-8$} & T102 & $24-2 \sim 24-6$ & $50 \sim 60$ & 砂交り砂利 & 71.7 & 7.3 & 51,768 & 67 & 1.62 & \multirow{3}{*}{1.44} \\
\hline & & & T104 & $24-4 \sim 24-6$ & " & $"$ & 38.2 & 3.1 & 5,670 & 50 & 1.21 & \\
\hline & & $D-7$ & T111 & $24-12 \sim 24-6$ & $"$ & " & 78.1 & 6.3 & 39,797 & 54 & 1.24 & \\
\hline & \multirow[t]{3}{*}{ 東海道戸塚国道改良 } & $"$ & $23-066$ & $26-7 \sim 26-9$ & 50 & 関東ローム & 48 & 7.9 & 4,729 & 26 & 0.77 & \multirow{3}{*}{0.64} \\
\hline & & " & 23-069 & $"$ & 40 & " & 44 & 10.6 & 1,057 & 19.8 & 0.48 & \\
\hline & & $"$ & $25-301$ & $"$ & 30 & " & 35 & 11.0 & 1,397 & 15.9 & 0.47 & \\
\hline \multirow[t]{3}{*}{ 北海道開発 } & \multirow[t]{3}{*}{$\mid$} & $\mathrm{D}-50$ & $24-142$ & $26-6 \sim 26-11$ & 30 & 砂利交 & 55 & 8.7 & 7,890 & 16.5 & 0.40 & \multirow{3}{*}{0.42} \\
\hline & & 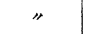 & $24-002$ & $"$ & $"$ & 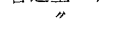 & 35 & 8.2 & 4,378 & 23.6 & 0.56 & \\
\hline & & B F & $26-087$ & $"$ & $"$ & " & 52 & 8.1 & 6,071 & 22.8 & 0.34 & \\
\hline \multirow[t]{6}{*}{ 建設省近畿|: } & \multirow[t]{4}{*}{ 挥保川今市築堤 } & B F & $25-145$ & $\mid 26-9 \sim 27-2$ & $30 \sim 40$ & 砂利交り矿 & 45.7 & 6.4 & 1,530 & 47.8 & 0.83 & \multirow{4}{*}{0.78} \\
\hline & & $\mathrm{D}-80$ & $25-151$ & $26-9 \sim 27-2$ & " & $"$ & 46.2 & 7.4 & 1,840 & 41.5 & 0.69 & \\
\hline & & " & 26-099 & $|26-12 \sim 27-2|$ & $"$ & " & 64.1 & 7.5 & 650 & 43.3 & 0.71 & \\
\hline & & B B III & $24-192$ & $|26-11 \sim 27-2|$ & $"$ & $"$ & 44.7 & 4.7 & 1,850 & 33.0 & 0.86 & \\
\hline & \multirow[t]{2}{*}{ 瀬田川南部堀削 } & $D-7$ & $24-309$ & $26-11 \sim 26-12$ & 30 & 砂利交り砂 & 59.0 & 6.3 & 5,900 & 45.0 & 0.69 & \multirow{2}{*}{0.65} \\
\hline & & B B III & $24-195$ & $"$ & $"$ & $"$ & 37.6 & 3.6 & 1,920 & 24.6 & 0.52 & \\
\hline
\end{tabular}


表一2.4 現 場 実 續 調 查 資 料 (No. 2)

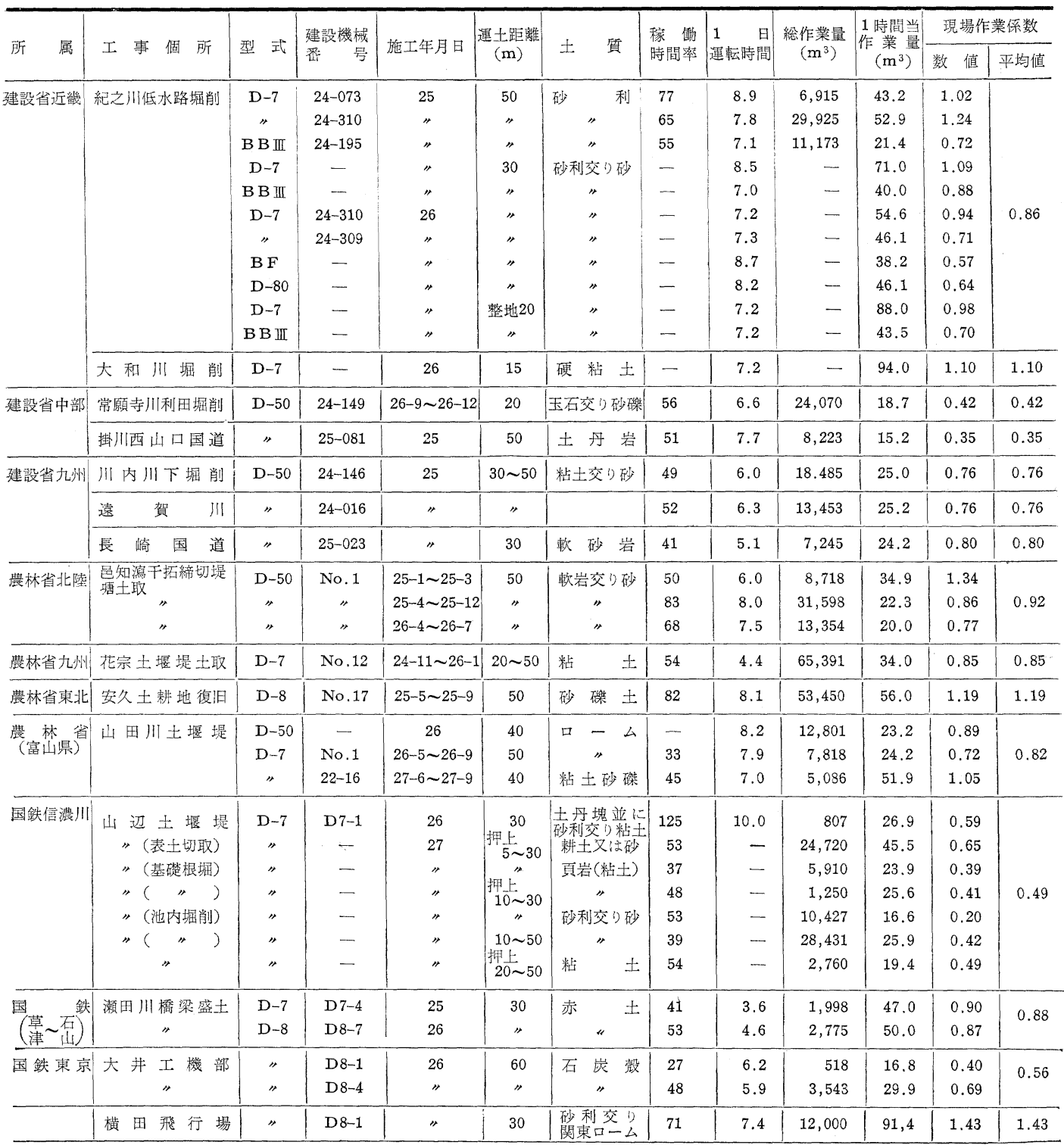

表一2.5 入間川改修工事における実績調査資料

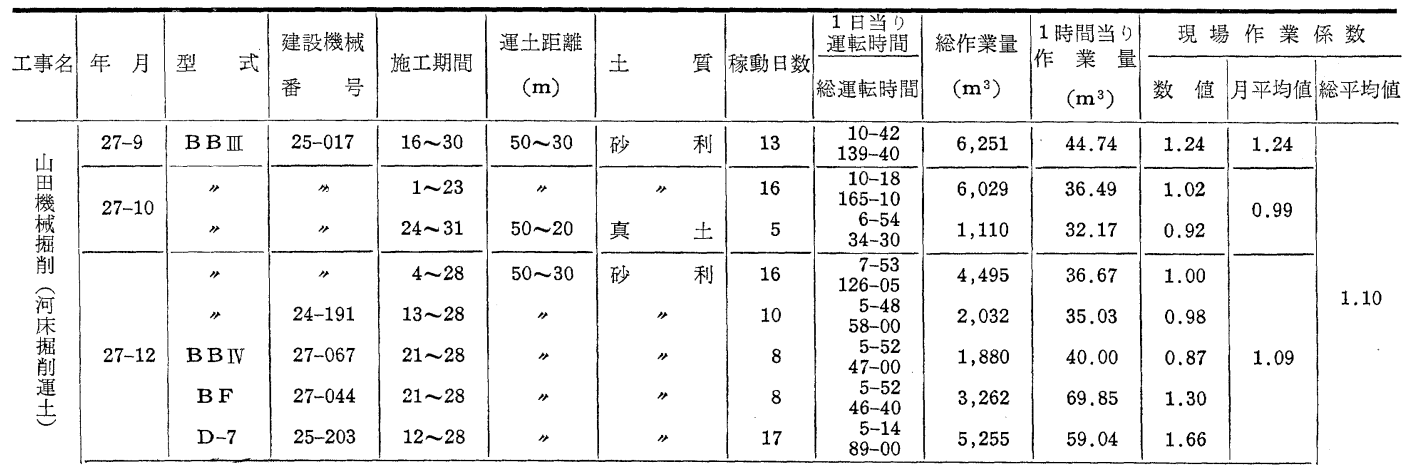




\begin{tabular}{|c|c|c|c|c|c|c|c|c|c|c|c|c|c|}
\hline & $28-1$ & $\begin{array}{l}\text { B B III } \\
\text { B B IV }\end{array}$ & $\begin{array}{l}25-017 \\
27-067\end{array}$ & $\begin{array}{l}4 \sim 17 \\
4 \sim 18\end{array}$ & $\begin{array}{c}60 \sim 30 \\
"\end{array}$ & 真 & $\begin{array}{l}14 \\
14\end{array}$ & $\begin{array}{r}5-03 \\
81-00 \\
6-10 \\
86-10\end{array}$ & $\begin{array}{l}3,240 \\
3,017\end{array}$ & $\begin{array}{l}40.00 \\
35.00\end{array}$ & $\begin{array}{l}1.23 \\
0.95\end{array}$ & 1.09 & \\
\hline \multirow{11}{*}{ 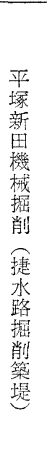 } & \multirow{8}{*}{$28-1$} & D-8 & $22-001$ & $6 \sim 18$ & $70 \sim 60$ & 小砂利交砂 & 11 & $\begin{array}{r}4-43 \\
52-00\end{array}$ & 2,600 & 50.00 & 1.37 & & \multirow{11}{*}{1.04} \\
\hline & & $"$ & $"$ & $19 \sim 31$ & $50 \sim 30$ & 真 $\quad \pm$ & 12 & $\begin{array}{r}5-10 \\
62-00\end{array}$ & 3,410 & 55.00 & 1.09 & & \\
\hline & & $D-7$ & 26-203 & $16 \sim 31$ & $"$ & 砂交り頁土 & 16 & $\begin{array}{r}5-52 \\
94-10\end{array}$ & 4,705 & 49.96 & 1.09 & & \\
\hline & & B F & 27-044 & $11 \sim 17$ & $60 \sim 50$ & 砂 & 6 & $\begin{array}{r}6-00 \\
36-00\end{array}$ & 1,620 & 45.00 & 1.12 & & \\
\hline & & " & $"$ & $18 \sim 30$ & $50 \sim 30$ & 直 土 & 13 & $\begin{array}{r}6-11 \\
80-20\end{array}$ & 4,015 & 49.98 & 1.05 & 1.09 & \\
\hline & & B BIV & $27-067$ & $24 \sim 31$ & $60 \sim 50$ & " & 8 & $\begin{array}{r}6-11 \\
49-30\end{array}$ & 1,338 & 27.03 & 0.88 & & \\
\hline & & B B III & $25-017$ & $17 \sim 25$ & $50 \sim 30$ & " & 8 & $\begin{array}{r}6-23 \\
43-00\end{array}$ & 1,376 & 32.00 & 1.00 & & \\
\hline & & $"$ & $24-191$ & $7 \sim 16$ & $60 \sim 50$ & 小砂利交砂 & 4 & $\begin{array}{r}5-27 \\
21-50 \\
\end{array}$ & 550 & 25.19 & 0.93 & & \\
\hline & \multirow{3}{*}{$28-2$} & D -7 & $26-203$ & $1 \sim 17$ & $40 \sim 30$ & \pm & 16 & $\begin{array}{r}6-34 \\
105-00\end{array}$ & 5,250 & 50.00 & 0.93 & & \\
\hline & & B B IV & $27-067$ & $1 \sim 20$ & " & " & 17 & $\begin{array}{r}6-48 \\
115-30\end{array}$ & 4,620 & 40.00 & 0.87 & 0.96 & \\
\hline & & B B III & $25-017$ & $1 \sim 18$ & " & $"$ & 7 & $\begin{array}{r}6-51 \\
48-00\end{array}$ & 1,920 & 40.00 & 1.12 & & \\
\hline
\end{tabular}

削し土砂をラダー掘削機の位置まで押上げする作業であり，“平塚新田機械掘削”は入間川の小支川である小畔川

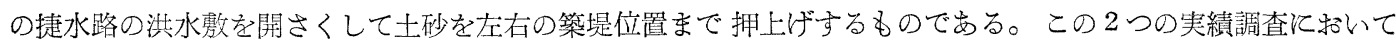
は係数の季節的変化，土質による変化括よび ブルドーザの型式の差異による変化を分析調查する目的で記録を整 理した。その結果季節的変化々施工期間が短期間であつたため求められなかつた。型式の差異とよる变化招よび 土質による変化についてね 図一2.2 そとの結果を示すが同一作業をしなかつてととと，資料数が少ないので明確 な判定がつかない。

表一2.6 現場作業係数の実績

図-2.2

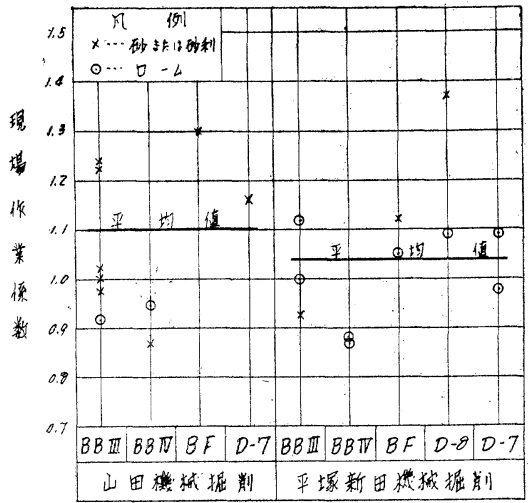

表一2.3〜表一2.5 亿より求めた工事現場の現場作 業係数をとの順位に並べると 表一2.6のと杼りにな る。表一2.6亿より晾かると扮り整地が最も現場作業 係数が大きく, 河川の掘削工事, アースダム工事, 道路 工事の順で，水分の多い土の処理が最子作業能率が悪 いことを知る。表一2.6 亿招いて現場作業係数 1.5 1.3 の籁团を $A$ とし以下 0.2 の範囲ごとに $B(1.3 \sim$ 1.1), $C(1.1 \sim 0.9), D(0.9 \sim 0.7), E(0.7 \sim 0.5)$, $F(0.5 \sim 0.3)$ として。

\section{(2) 現場作業係数推定表}

これから工事しようとする現場の現場作業係数は類 似の実績基いて決めるのがよいが，表一2.3〜表一 2.6 の現場作業係数の結果を工種別捛よび主たる作業 条件から分類して 表一 2.7 江示す現場作業係数推定表 を作成した。表一 $2.7 \mathrm{r}$ 整地，アースダム工事，河川改修，道路改良の 4 つ分類してある。従つてそれぞれの地域的な土工の作業条件

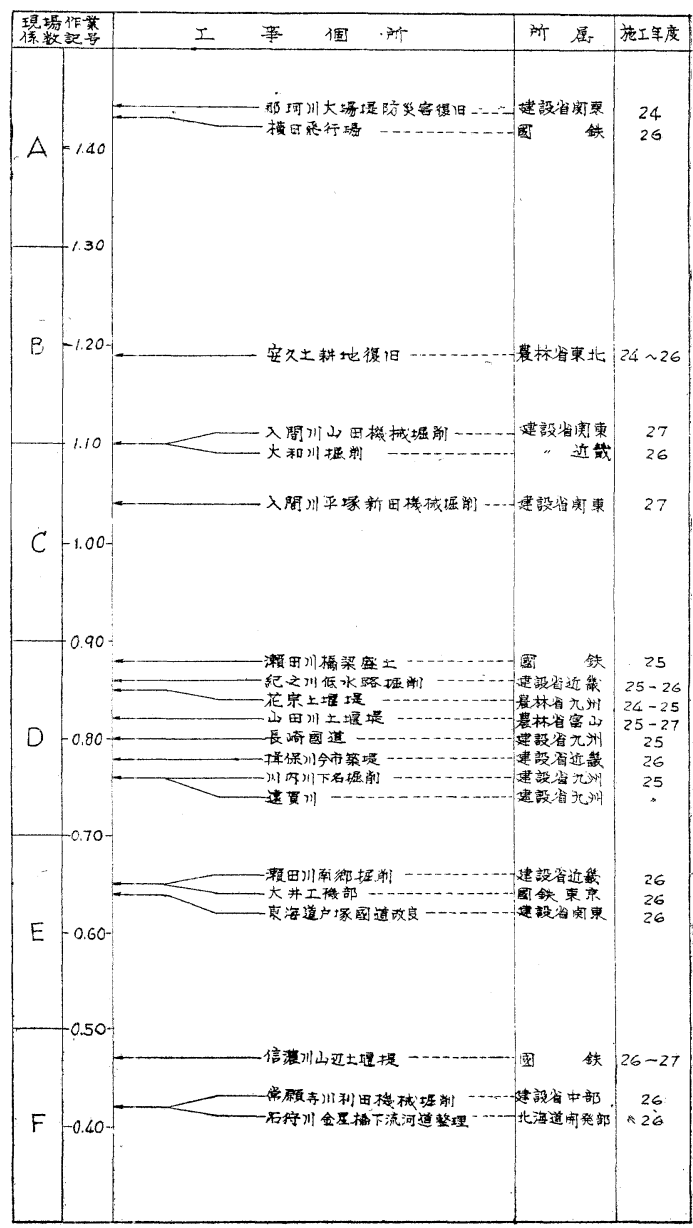


が変化した場合の現場作業係数推定表を作成する必要のある場合は 表一2.7 を参考として別作成して使用する と便利である。

次に現場作業係数推定表の使用法について1例により説明する

(例) 道路改良の切土運搬を伴う盛土工事と扔いて土質がローム質土で乾燥(稕固め最適含水率より含水量が少 い場合）しているときは 表一2.7 亿より現場作業係数ね 0.8 0.9を選び，土が中位の湿り（締固め最適含 水率より湿つている) のときね $0.5 〜 0.7$ を選ぶ。

表一2.7 現 場 作 業 係 数 推 定 表

\begin{tabular}{|c|c|c|c|c|c|c|c|c|c|c|c|c|c|c|}
\hline \multirow{3}{*}{ 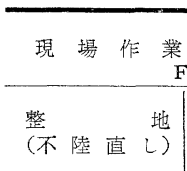 } & F 係 数 1 & $i^{5}$ & \multirow{2}{*}{$\begin{array}{l}1.4 \\
\text { 少 }\end{array}$} & $i^{3}$ & 1.2 & $\begin{array}{cc} & \\
1.0 & 0 . \\
\end{array}$ & \multicolumn{2}{|c|}{0.8} & 0 & \multicolumn{3}{|c|}{0.6} & 0.5 & 0.4 \\
\hline & 不陸の程度 & & & $w$ & 中 & 位 & 大 & き & $w$ & & 障 & 害 & w & b \\
\hline & \pm & 砂 & 砂 質 土 & $\overline{\square-\Delta}$ & 砂 質 土 & 粘 & 土 & 交 & b) & & 走 & 路 & 惠 & L \\
\hline \multirow{2}{*}{$\begin{array}{l}\text { ア } \text { 不多公 } \\
\text { (土運搬) }\end{array}$} & 土の湿り & & & & & 乾䍄 & \multicolumn{2}{|c|}{ 適 } & \multicolumn{3}{|c|}{ 度 } & 湿 & \multicolumn{2}{|r|}{ 潤 } \\
\hline & 土 & & & & & 砂質土 & 口 & - & 厶 & 粘 & 土 & $\square-\Delta$ & 粘 & 土 \\
\hline \multirow{2}{*}{$\begin{array}{l}\text { 河 川改修 } \\
\text { (掘削, 運搬) }\end{array}$} & 工事の種類 & & & \multicolumn{5}{|c|}{ 高水敷掘削または築堤 } & \multicolumn{2}{|c|}{ 低 水 路 } & 末 & た は水 & 中 & 掘 削 \\
\hline & 土 & & & 砂利 交 & 1) 土砂 & 砂 質土 & 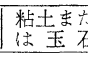 & & $\begin{array}{l}\text { 砂利交り } \\
\pm \quad \text { 砂 }\end{array}$ & 砂 & , & 土 & \multicolumn{2}{|c|}{ |粘土または湿土 } \\
\hline \multirow{2}{*}{$\begin{array}{l}\text { 道 路 改 良 } \\
(\text { 切 } \\
\text { 盛 土) }\end{array}$} & 土の湿り & & & & & \multicolumn{3}{|l|}{ 乾 } & \multicolumn{2}{|l|}{ 中 } & \multicolumn{2}{|r|}{ 位 } & 湿 & 潤 \\
\hline & \pm & & & & & 砂 質土। & $a-1$ & & 砂 質土 & 口 & . & $厶$ & 口- & 么, 粘 土 \\
\hline
\end{tabular}

\section{表一2.8土量換算係数表}

\begin{tabular}{|c|c|c|c|}
\hline \multirow{2}{*}{ 土 } & \multicolumn{3}{|c|}{ 換算すべき土の状態 } \\
\hline & $\begin{array}{c}\text { 地山のまま } \\
\text { (あと坪) }\end{array}$ & $\begin{array}{l}\text { 掘り驰めた } \\
\text { 場 合 }\end{array}$ & $\begin{array}{l}\text { 縍固め庄 } \\
\text { 場 }\end{array}$ \\
\hline 砂 & 0.90 & 1.00 & 0.86 \\
\hline 普 & 0.80 & 1.00 & 0.72 \\
\hline 粘 & 0.70 & 1.00 & 0.63 \\
\hline 砂交り砂 利 & 0.85 & 1.00 & 0.91 \\
\hline 砂 & 0.88 & 1.00 & 0.91 \\
\hline 固 結した砂 利 & 0.70 & 1.00 & 0.91 \\
\hline $\begin{array}{l}\text { 石戌岩, 砂岩, その他 } \\
\text { 軟岩を破砕したをの }\end{array}$ & 0.61 & 1.00 & 0.74 \\
\hline $\begin{array}{l}\text { 花嵐岩, 莣武岩, その他 } \\
\text { 硬岩吉破碎したむの }\end{array}$ & 0.59 & 1.00 & 0.77 \\
\hline 小割した石塊 & 0.57 & 1.00 & 0.80 \\
\hline 䑁破した岩石の大塊 & 0.56 & 1.00 & 0.72 \\
\hline
\end{tabular}

\subsection{5. 土量換算係数 $f$}

土量換算係数 (conversion factors for earth-volume change) は従来より表一 2.8 亿示すものが使用さ れている。(2.1) 式祘よび (2.2) 式で土工量を求める 場合 $f$ を 1.0 とすると掘り弛めた状態和ける容積が 算出される。また自然状態のまま (あと坪)あるいね 締固められた容積で算出したいときは，各土質応じ て表一2.8の左欄あるい江右闌のそれぞれ該当の係数 を使用すればよい。

\section{3 各種ブルドーザによる土工量の算定}

2.3.1. ブルドーザ土工作業計算尺について

(2.2) 式の土工量の実用算定公式を計算するための計算尺を考案設計した。これとよると現場作業員または運 転員等に対しても土工量の計算を容易にし, また土工作業の実績より絶えず現場作業係数を逆算することにより, 日々の作業の難易性を容易に知るととができる（計算尺ほ日本建設機械化協会発売中）。

（注）本計算尺は昭 28-24209にて特許申請中のものである。本計算尺は製作において目盛の位置が若干狂つて作られているためこれで計算され た土工量は約 1 割増大して求められる。計算尺における各尺の目盛の振り方は次のようである。

土量換算係数 $(f) \cdots \cdots$ 逆方向対数目盛

ブレード面積 (B) $\cdots \cdots$ 正方向対数目盛 $80 / 36(=2.22) に f$ の 1.0 を合せる

現場作業係数 $(F) \cdots \cdots$. 正方向対数目盛

作業土量 (P) ……正方向対数目盛

連土距離 (D) ……正方向対数目盛 $160 \mathrm{~m}$ にPの $10 \mathrm{~m}^{3}, 10 \mathrm{~m}$ に $P$ の $100 \mathrm{~m}^{3}$ を合わせる。

\subsection{2. 土工量の計算実例}

(2.2) 式により，わが国で使用されるブルドーザの 型式別に，現場作業係数の変化に従つて計算した時間 当り土工量社表一2.9〜表一2.17のと和りである。た だしこの表はいづれも土量換算係数の $f=1$ 場合で, あと坪また沵出来高で土工量を求めるとき流，それぞ れの場合についての土量換算係数をこれに乗じなけれ ばならない。
表一2.9 D-8ブルドーザ土工量 $\left(\mathrm{m}^{3} / \mathrm{h}\right)$

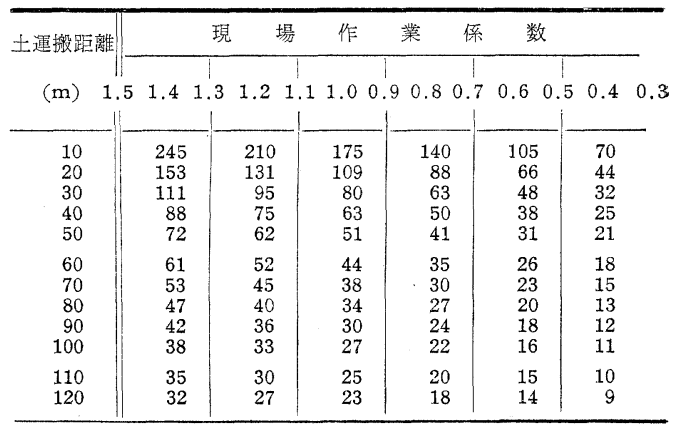


表一2.10 D-7 ブルドーザ土工量 $\left(\mathrm{m}^{3} / \mathrm{h}\right)$

土運搬距離

(m) $\quad \begin{array}{lllllllllllllllll}1.5 & 1.4 & 1.3 & 1.2 & 1.1 & 1.0 & 0.9 & 0.8 & 0.7 & 0.6 & 0.5 & 0.4 & 0.3\end{array}$

\begin{tabular}{r|r|r|r|r|r|r} 
& & & & & & \\
\hline 10 & 223 & 191 & 159 & 127 & 96 & 64 \\
20 & 139 & 119 & 99 & 79 & 60 & 40 \\
30 & 101 & 87 & 72 & 58 & 43 & 29 \\
40 & 80 & 68 & 57 & 46 & 34 & 23 \\
50 & 66 & 56 & 47 & 37 & 28 & 19 \\
& & & & & & \\
60 & 56 & 48 & 40 & 32 & 24 & 16 \\
70 & 49 & 42 & 35 & 28 & 21 & 14 \\
80 & 43 & 37 & 31 & 25 & 18 & 12 \\
90 & 39 & 33 & 27 & 22 & 16 & 11 \\
100 & 35 & 30 & 25 & 20 & 15 & 10 \\
110 & 32 & 27 & 23 & 18 & 14 & 9 \\
120 & 29 & 25 & 21 & 17 & 13 & 8 \\
\hline
\end{tabular}

表一2.12ＮTK-7ブルドーザ土工量 $\left(\mathrm{m}^{3} / \mathrm{h}\right)$

土運搬距離

現 場 作 業 係 数

(m) $\quad \begin{array}{llllllllllllllllll}1.5 & 1.4 & 1.3 & 1.2 & 1.1 & 1.0 & 0.9 & 0.8 & 0.7 & 0.6 & 0.5 & 0.4 & 0.3\end{array}$

\begin{tabular}{|c|c|c|c|c|c|c|}
\hline 10 & 218 & 186 & 155 & 124 & 93 & 62 \\
\hline 20 & 137 & 117 & 97 & 78 & 58 & 39 \\
\hline 30 & 99 & 85 & 71 & 56 & 42 & 28 \\
\hline 40 & 78 & 66 & 56 & 44 & 33 & 22 \\
\hline 50 & 64 & 55 & 46 & 37 & 28 & 18 \\
\hline 60 & 54 & 46 & 39 & 31 & 23 & 16 \\
\hline 70 & 47 & 41 & 34 & 27 & 20 & 14 \\
\hline 80 & 42 & 36 & 30 & 24 & 18 & 12 \\
\hline 90 & 37 & 32 & 27 & 22 & 16 & 11 \\
\hline 100 & 34 & 29 & 24 & 20 & 15 & 10 \\
\hline 110 & 31 & 27 & 22 & 18 & 13 & 9 \\
\hline 120 & 29 & 24 & 20 & 16 & 12 & 8 \\
\hline
\end{tabular}

表一2.14ＢBIII ブルドーザ土工量 $\left(\mathrm{m}^{3} / \mathrm{h}\right)$

土運搬距離

$\begin{array}{lllllllllllllllll}\text { (m) } & 1.5 & 1.4 & 1.3 & 1.2 & 1.1 & 1.0 & 0.9 & 0.8 & 0.7 & 0.6 & 0.5 & 0.4 & 0.3\end{array}$

\begin{tabular}{r|r|r|r|r|r|r} 
& & & & & \\
\hline 10 & 158 & 136 & 113 & 91 & 68 & 45 \\
20 & 99 & 85 & 71 & 56 & 43 & 28 \\
30 & 72 & 62 & 52 & 41 & 31 & 21 \\
40 & 57 & 48 & 40 & 32 & 24 & 16 \\
50 & 46 & 40 & 33 & 27 & 20 & 13 \\
& & & & & & \\
60 & 40 & 34 & 28 & 22 & 17 & 11 \\
70 & 35 & 30 & 25 & 20 & 15 & 10 \\
80 & 31 & 26 & 22 & 17 & 13 & 9 \\
90 & 27 & 23 & 19 & 15 & 12 & 8 \\
100 & 25 & 21 & 18 & 14 & 11 & 7 \\
110 & 23 & 19 & 16 & 13 & 10 & 6 \\
120 & 21 & 18 & 15 & 12 & 9 & 6 \\
\hline
\end{tabular}

表一2.16 NTK-4ブルドーザ土工量 $\left(\mathrm{m}^{3} / \mathrm{h}\right)$

土運搬距離

現場 作 業 係 数

(m) $\quad \begin{array}{llllllllllllllllll} & 1.5 & 1.4 & 1.3 & 1.2 & 1.1 & 1.0 & 0.9 & 0.8 & 0.7 & 0.6 & 0.5 & 0.4 & 0.3\end{array}$

\begin{tabular}{r|r|r|r|r|r|r} 
& & & & & & \\
\hline 10 & 127 & 109 & 91 & 72 & 54 & 36 \\
20 & 79 & 68 & 57 & 45 & 34 & 23 \\
30 & 58 & 49 & 41 & 33 & 25 & 17 \\
40 & 45 & 39 & 32 & 26 & 19 & 13 \\
50 & 37 & 33 & 27 & 21 & 16 & 11 \\
& & & & & & \\
60 & 32 & 27 & 22 & 18 & 14 & 9 \\
70 & 28 & 24 & 20 & 16 & 12 & 8 \\
80 & 24 & 21 & 17 & 14 & 11 & 7 \\
90 & 22 & 19 & 15 & 12 & 9 & 6 \\
100 & 20 & 17 & 14 & 11 & 8 & 6 \\
110 & 18 & 15 & 13 & 10 & 8 & 5 \\
120 & 17 & 14 & 12 & 9 & 7 & 5 \\
\hline
\end{tabular}

表一2.11 D-80, BF ブルドーザ土工量 $\left(\mathrm{m}^{3} / \mathrm{h}\right)$

\begin{tabular}{|c|c|c|c|c|c|c|c|c|c|c|c|}
\hline \multirow{2}{*}{ 土運搬距離 } & \multicolumn{3}{|c|}{ 現 } & 場 & 作 & & 業 & \multicolumn{4}{|c|}{ 数 } \\
\hline & & $T$ & & & & & & & & & \\
\hline (m) 1.5 & 1.4 & 1.3 & 1.2 & 1.1 & 1.0 & 0.9 & 0.8 & 0.7 & 0.60 .5 & $\begin{array}{ll}5 & 0.4\end{array}$ & 0.3 \\
\hline 10 & 236 & & 203 & & 159 & & 135 & & 101 & 68 & \\
\hline 20 & 148 & & 127 & & 106 & & 85 & & 63 & 42 & \\
\hline 30 & 108 & & 92 & & 77 & & 62 & & 46 & 31 & \\
\hline 40 & 84 & & 72 & & 60 & & 48 & & 36 & 24 & \\
\hline 50 & 70 & & 60 & & 50 & & 40 & & 30 & 20 & \\
\hline 60 & 59 & & 51 & & 42 & & 34 & & 25 & 17 & \\
\hline 70 & 51 & & 44 & & 37 & & 30 & & 22 & 15 & \\
\hline 80 & 46 & & 39 & & 33 & & 26 & & 20 & 13 & \\
\hline 90 & 41 & & 35 & & 29 & & 23 & & 18 & 12 & \\
\hline 100 & 37 & & 32 & & 26 & & 21 & & 16 & 11 & \\
\hline 110 & 34 & & 29 & & 24 & & 19 & & 15 & 10 & \\
\hline 120 & 31 & & 27 & & 22 & & 17 & & 13 & 9 & \\
\hline
\end{tabular}

表一2.13 BBIV ブルドーザ土工量 $\left(\mathrm{m}^{3} / \mathrm{h}\right)$

\begin{tabular}{|c|c|c|c|c|c|c|}
\hline 土運搬距離 & 現 & 場 & 作 & 業 & 係 & 数 \\
\hline
\end{tabular}

(m) $\quad \begin{array}{llllllllllllllllll}1.5 & 1.4 & 1.3 & 1.2 & 1.1 & 1.0 & 0.9 & 0.8 & 0.7 & 0.6 & 0.5 & 0.4 & 0.3\end{array}$

\begin{tabular}{r||r|r|r|r|r|r} 
& & & & & & \\
\hline 10 & 198 & 170 & 142 & 114 & 85 & 57 \\
20 & 124 & 107 & 89 & 71 & 53 & 35 \\
30 & 91 & 77 & 65 & 52 & 39 & 25 \\
40 & 71 & 61 & 51 & 41 & 31 & 21 \\
50 & 58 & 50 & 42 & 34 & 25 & 17 \\
60 & 50 & 42 & 36 & 28 & 21 & 14 \\
70 & 43 & 37 & 31 & 25 & 19 & 12 \\
80 & 38 & 33 & 27 & 22 & 17 & 11 \\
90 & 34 & 29 & 25 & 20 & 15 & 10 \\
100 & 31 & 27 & 22 & 18 & 14 & 9 \\
110 & 28 & 24 & 20 & 16 & 12 & 8 \\
120 & 26 & 22 & 19 & 15 & 11 & 7 \\
\hline
\end{tabular}

\section{表-2.15 D-50ブルドーザ土工量 $\left(\mathrm{m}^{3} / \mathrm{h}\right)$}

土運搬距離

(m) $\quad \begin{array}{lllllllllllllllll}.5 & 1.4 & 1.3 & 1.2 & 1.1 & 1.0 & 0.9 & 0.8 & 0.7 & 0.6 & 0.5 & 0.4 & 0.3\end{array}$

\begin{tabular}{r|r|r|r|r|r|r} 
& & & & & & \\
\hline 10 & 142 & 122 & 102 & 81 & 61 & \\
20 & 90 & 76 & 63 & 50 & 38 & 25 \\
30 & 64 & 55 & 46 & 37 & 28 & 18 \\
40 & 51 & 44 & 36 & 29 & 22 & 15 \\
50 & 42 & 36 & 30 & 24 & 18 & 12 \\
60 & 36 & 31 & 25 & 20 & 15 & 10 \\
70 & 31 & 26 & 22 & 17 & 13 & 9 \\
80 & 27 & 23 & 20 & 16 & 12 & 8 \\
90 & 25 & 21 & 18 & 14 & 11 & 7 \\
100 & 22 & 19 & 16 & 13 & 10 & 6 \\
110 & 20 & 17 & 14 & 12 & 9 & 6 \\
120 & 19 & 16 & 13 & 11 & 8 & 5 \\
\hline
\end{tabular}

表一2.17 D-120ブルドーザ土工量 $\left(\mathrm{m}^{3} / \mathrm{h}\right)$

土運搬距離

(m) $\quad \begin{array}{llllllllllllllll}1.5 & 1.4 & 1.3 & 1.2 & 1.1 & 1.0 & 0.9 & 0.8 & 0.7 & 0.6 & 0.5 & 0.4 & 0.3\end{array}$

\begin{tabular}{|c|c|c|c|c|c|c|}
\hline 10 & 258 & 221 & 180 & 144 & 108 & 72 \\
\hline 20 & 161 & 138 & 112 & 90 & 68 & 45 \\
\hline 30 & 117 & 100 & 82 & 65 & 49 & 33 \\
\hline 40 & 92 & 79 & 64 & 51 & 39 & 26 \\
\hline 50 & 76 & 65 & 53 & 42 & 32 & 21 \\
\hline 60 & 65 & 55 & 45 & 36 & 27 & 18 \\
\hline 70 & 56 & 48 & 39 & 31 & 24 & 16 \\
\hline 80 & 50 & 43 & 35 & 28 & 21 & 14 \\
\hline 90 & 45 & 38 & 31 & 25 & 19 & 12 \\
\hline 100 & 40 & 35 & 28 & 23 & 17 & 11 \\
\hline 110 & 37 & 32 & 26 & 21 & 15 & 10 \\
\hline 120 & 34 & 29 & 24 & 19 & 14 & 9 \\
\hline
\end{tabular}




\subsection{3. 土工量の算定上考慮を要する問題}

\section{(1) タイムスタディーに対するる補正}

土工量算定にさきだつて，サイクルタイムの基準を知るためにタイムスタディー(作業時間分析調査)を行うこ とがある。しかしこのタイムスタディーについては運転員にそれを行うことを予告して行われた作業の1 サイク ルタイムの割合をるつて 1 時間の土工量を算定したものと，実作業 1 時間に和ける寒績土工量とを比較すると後 者が前者の $64.4 \%$ \%゙あるととが次の現地試験より明らかてされた。試験は北海道緋牛内美沅間第二工区道路改良

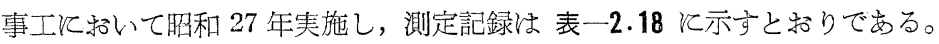

この試験の結果，運転員飞通告された，タイムスタディーにより1サイクルタイムを測定し，これねより土工

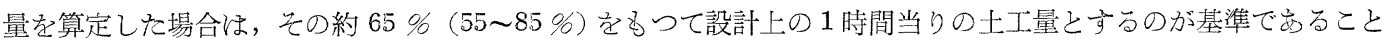
を知施。

表一2.18 タイムスタデイーを行つた場合と実作業との比較

\begin{tabular}{|c|c|c|c|c|c|c|c|c|c|c|c|c|}
\hline \multirow{2}{*}{ 式 } & \multirow{2}{*}{ 土 } & \multirow{2}{*}{ 質 } & \multicolumn{2}{|r|}{ 速 } & \multirow[b]{2}{*}{ 距 } & \multirow{2}{*}{$\mid \begin{array}{cccc}1 & \text { サイ } \\
\text { 夕 } & 1 & 厶\end{array}$} & \multirow{2}{*}{$\begin{array}{c}1 \text { 回平均 } \\
\text { 作 業 量 }\end{array}$} & \multicolumn{3}{|c|}{ 測定時の作業值 } & \multirow{2}{*}{$\begin{array}{l}1 \text { 日 } \\
\text { 実作業量 }\end{array}$} & \multirow{2}{*}{ 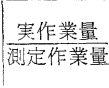 } \\
\hline & & & 前 進 & 後 進 & & & & $\begin{array}{ll}1 & \text { 時間 } \\
\text { 回 } & \text { 数 }\end{array}$ & $\begin{array}{l}11 \text { 時間 } \\
\text { 作業量 }\end{array}$ & $\begin{array}{l}1 \\
\text { 作量量 }\end{array}$ & & \\
\hline 菱 B B III & 粘 & & $1^{\text {速 }}$ & $3^{\text {速 }}$ & $\begin{array}{c}\mathrm{m} \\
40\end{array}$ & $\begin{array}{l}\text { 分 秒 } \\
2-22\end{array}$ & $2^{\mathrm{m}^{3}}$ & 25.3 & $5 n .6$ & $\mathrm{~m}^{3}$ & $\begin{array}{l}\mathrm{m}^{3} \\
192\end{array}$ & $56.6^{\%}$ \\
\hline$"$ & 火 & 死 & " & $"$ & 100 & $3-47$ & 2 & 15.9 & 31.8 & 213 & 123 & 57.7 \\
\hline * & & & $"$ & $"$ & 100 & $4-55$ & 2 & 12.1 & 24.2 & 162 & 123 & $* 75.9$ \\
\hline 特 NTK-7 & 粘 & \pm & 1 & 2 & 80 & $2-42$ & 2.3 & 22.2 & 51.1 & 322 & 122 & 37.8 \\
\hline$"$ & & & $"$ & " & 100 & $3-49$ & 2.3 & 15.7 & 36.1 & 227 & 103 & 45.3 \\
\hline キヤタピラーD-7 & 転不 & 1) 土 & 1 & 3 & 60 & $3-06$ & 2.8 & 19.4 & 54.3 & 397 & 234 & 59.0 \\
\hline$"$ & & & " & $"$ & 80 & $4-25$ & 2.8 & 13.6 & 38.1 & 278 & 241 & 86.7 \\
\hline$"$ & & & $"$ & " & 100 & $5-19$ & 2.8 & 11.2 & 31.4 & 229 & 215 & 93.8 \\
\hline キャタピラーD-8 & & & 2 & 4 & 120 & $4-31$ & 3.5 & 13.3 & 46.6 & 321 & 251 & 78.1 \\
\hline 特 NTK-7 & 粘 & 土 & 1 & 2 & 100 & $4-31$ & 2.3 & 13.3 & 30.6 & 193 & 103 & 53.3 \\
\hline 各車 平均 & & & & & & & & & & & & 64.4 \\
\hline
\end{tabular}

（注）*印は助手が運転したものを示す。

(2) 運転員の熟練度による補正

ブルドーザとよる土工作業に招いては運転員の 熟練度により作業能率差を生ずる。これに関する現場試験の 結果は 5 6 年の運転経験のある運転員（十分一人前の技倆あるもの）による1 サイクルタイムを100とすると， 2 年の運転経験の運転員による1サイクルタイムは略 110 と見做される。試験ほ北海道緋牛内美幌間第二工区道 路改良工事飞执いて䀡和 27 年実施し，測定記録は表一2.19 和よび 表一2.20 亿示すと招りである。

表一2.19 運転員の熟練度の差異によるサイクルタイムの比較（No.1）キャタピラD-8ブルドーサ

\begin{tabular}{|c|c|c|c|c|c|c|c|}
\hline 経 験 & 年 数 & 排 土 時 間 & ギャ一入換時間 & 後 退 時，間 & キャ一入換時間 & 計(サイクルタイム) & 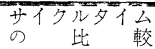 \\
\hline 6 & 年 & $1-50^{\text {行 }}$ & $0-03^{\text {分 }}$ & $2-23^{\text {分 }}$ & $0-02^{\text {分 }}$ & 分 $-18^{\text {秒 }}$ & $100^{\%}$ \\
\hline 2 & 年 & $2-07$ & $0-03$ & $2-32$ & $0-02$ & $4-45$ & 110 \\
\hline
\end{tabular}

（注）排土は下り勾配 $15 \%$ 土質は転石交り土距離 $120 \mathrm{~m}$ 作業条件不良（昭 27.7.19）

表一2.20 運転員の熟練度の差異によるサイクルタイムの比較 (No.2) 三菱日本 BBIII アングルドーザ

\begin{tabular}{|c|c|c|c|c|c|c|c|}
\hline 経 駼 & 年 数 & 排 土 時 間 & 甫ャ一入換時間 & 後退 時 間 & ギャ一入換時間 & 計(サイクルタイム) & $\begin{array}{l}\text { サイクル夕イ } \\
\text { の比 較 }\end{array}$ \\
\hline 5 & 年 & $\begin{array}{l}\text { 分 } \\
3-17.6\end{array}$ & 你 02.6 & 分 $1-07.6$ & 分 $-03^{\text {秒 }}$ & 分 $4-30.8$ & $100^{\%}$ \\
\hline 2 & 年 & $3-34.3$ & $0-02.6$ & $1-14.3$ & $0-04$ & $4-55.2$ & 109 \\
\hline
\end{tabular}

（注）土質は火山灰土，距離 $100 \mathrm{~m}$ ，作業条件良好（昭 27.8.8）

\section{第 3 章 使用料等の算定}

\section{1. 概 説}

従来より土木工事に使用されていた機械はブルドーザ，パワーショベル等の 重土工機械に比較して構造が単純:

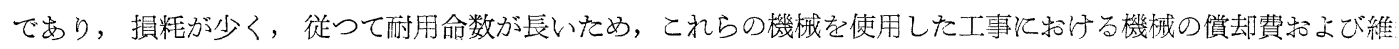
持修理費は金額も少いので，工事経費の算定にはさして問題とならなかつた。

これそ反してブルドーザによる土工のみならず最近の機械化工事に执いては，工事経費の5ち 機械償却費と維 
持修理費が大きな構成要素として占められるようになつた。それ故，ブルドーザ等の重土工機械については，そ の償却費㔚よび，維持修理費についてはその算定の基準を新た求める必要がある。

すなわら維持修理費の基準についてね，各種使用条件に応じた実績を集計整理することにより求めることるで きるが，機械を購入してより廃暂するまでの実績を記録することは容易ではない。

償却費についてはいかなる償却方法を適用するかにより，償却率つ㭙間的変化が種々異なり，ブルドーザ等の 建設機械の運用に最も適合する償却方法についての研究を必要とする。

工事用機械の償却方法には税法上の減価償却その他考兄られるが，単位運転時間についての 償却費々維持修理 費の合計が，機械の新旧の別なく常に一定の金額となるという仮定に基いて 償却率を決定する使用料コンスタン トの贘却法が，使用料の算定の上からもまた土工単価の積算の上からも，他の償却方法に比較して最も便利であ るととを知るであるう。

この研究に括いてほ上述の機械の使用料コンスタントの原則に従つて修理費, 使用料, 残存価格招よび償却費 の算定式をあた党，かつ物価の変動怙よび簿価の評価替光した場合の使用料の算定式を求めることができた。

また更に機械の管理費も計算に入れた場合の使用料の算定式も最も実用的な場合として求めるととができた。

\section{2. 購入費, 修理費, 使用料, 残存価格, 償却費等の基本的関係およびこれらの算定式}

\subsection{1. 購入費，修理費累計および経済的耐用時間の関係}

使用料算定公式等を求めるために次の購入費と修理費と運転時間の関係を用いる。(図一 3.1 参照)

図-3.1

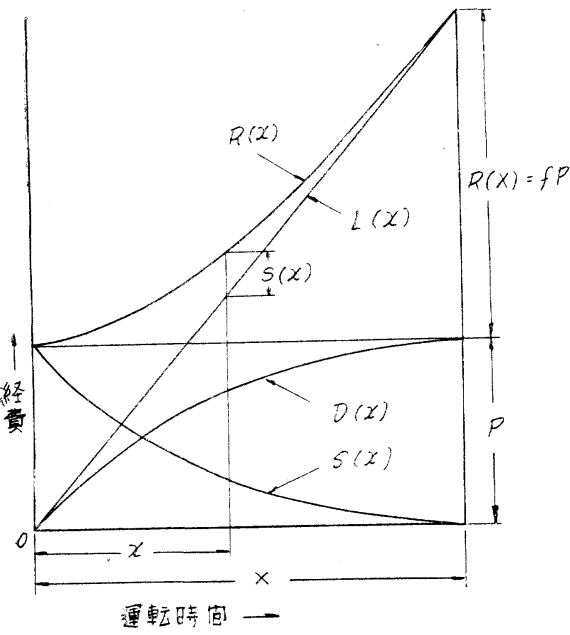

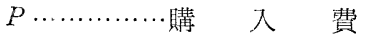

$R(x) \quad \cdots \cdots \cdots$ 運転時間 $x$ までの修理費累計

$x \ldots \ldots \ldots \ldots \ldots$. 経済的耐用時間

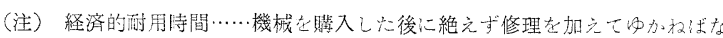
らない。ところが運転時間が経過するにつれて, 修理費の割合がきる なる傾向が多るので，運転時間当りの購入費飞修理費を合計した值け一 定の軍転侍間か経過したとさに最小の檤をとる。この心うな運転時間台 経济的耐用恃間とい5。

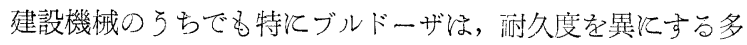
くの部分から構成されているから，維持修理費と運転時間の関 係は，乙れらの部分を修理するための費用と，これらの部分の 耐久度の関係で蒋化する。乞の傾向は運転時間の長くなるほど 運転時間当りの維持修理費がかさんでくる。

また比較的大きな修理洔々行われ，その効果々とれ以後 の運転時間に現われるものであるから，実際に起る維持修理の 支出ふ決して期間的飞均等飞配分されない。

すなわち図一-3.2 亿点線で示すどとく，た委たま大きな修理 が起つた期間に涼，それだけ経費が大きくなるので，この不均衡高均等化して考光る必要がある。図一3.2の実線 がそれで岕る。従つて修理費累計曲線は運転時間が零のとき修理費つ累計が零を起点として曲線で， $m, n$ を機種 そより異なる任意の常数として次の関係式が求められる。

$$
R(x)=m \cdot x^{n} \cdot P
$$

経済的耐用時間までの修理費の累計の購入費汶対する割合を $f$ とすると

$$
R(X)=f \cdot P
$$

\section{図-3.2}

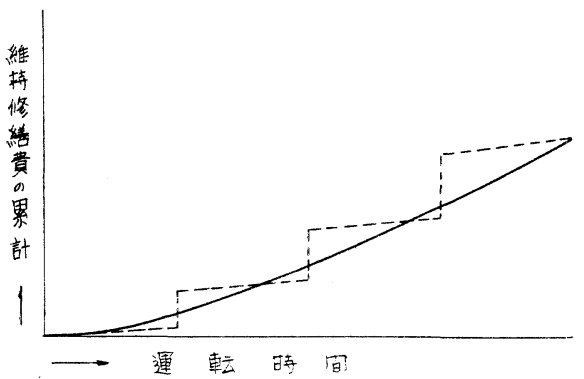

経済的耐用時間 $X$ ほ $R(x)$ の曲線と原点より切線气引い た切点の示す時間であることにより

$$
\left|\frac{d R(x)}{d x}\right|_{x=X}=m \cdot n \cdot X^{n-1} \cdot P=\frac{1+f}{X} \cdot P
$$

(3.1)，(3.2) 式老(3.3) 式代入して

$$
\begin{aligned}
& m \circ X^{n} \cdot(n-1)=1 \quad f \circ(n-1)=1 \\
& n=1+\frac{1}{f} \ldots \ldots \ldots \ldots \ldots \ldots \ldots \ldots \ldots \ldots \ldots \ldots \ldots \ldots \ldots \ldots \ldots \ldots
\end{aligned}
$$

修理費累計 $R(x)$ 婉(3.1)，(3.2) 特よび (3.4) 式の関 係から 


$$
R(x)=f \cdot P \cdot\left(\frac{x}{X}\right)^{(1+1 / f)}
$$

3.2.2. 時間当り修理費 $r(x)$

(3.5) 式を $x$ 亿ついて微分して求める

$$
r(x)=\frac{d R(x)}{d x}=f \cdot P \cdot\left(1+\frac{1}{f}\right)\left(\frac{x}{X}\right)^{(1+1 / f)} \cdot \frac{1}{x}
$$

\subsection{3. 残存価格 $S(x)$}

$$
S(x)=P+R(x)-L(x)=P \cdot\left\{\left(1+\frac{1}{f}\right) \cdot\left(\frac{x}{X}\right)^{(1+1 / f)}-(1+f) \cdot\left(\frac{x}{X}\right)\right\}
$$

米国に拾いては経済的西用時間に招ける残存価格を零としている。すなおら

$$
S(X)=0
$$

しかし，わが国では経済的耐 用時間に和ける残存価格を零と するのは適当でなく，スタラッ プ価格 $P_{S}$ だけ残ると考えねば ならない。

この場合, 経済的耐用時間の とき残存洒格が丁度スクラッ プ価格になる場合と（図一3.3 参照),残存価格が経済的耐用時 間より短かい $X_{S}$ に掠いてスク ラップ洒格注り, 以後, 経済 的耐用時間末では残存価格が変 化しない場合（図-3.4 参照）

図-3.3 $\left(s(x)=P_{3}\right)$

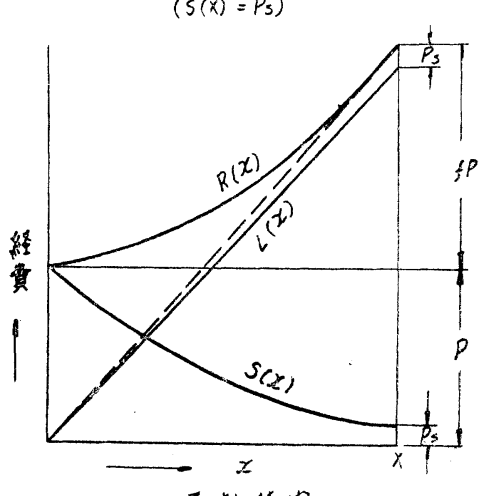

運就时用
园-3.4

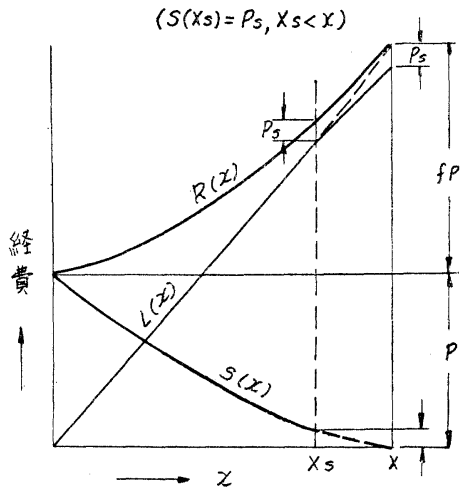

運鼓晓间

の二通りが考えられる。

\subsection{4. 償却費累計 $\boldsymbol{D}(\boldsymbol{x})$}

$$
\begin{aligned}
D(x) & =P-S(x) \\
& =L(x)-R(x) \\
& =P\left\{(1+f)\left(\frac{x}{X}\right)-f \circ\left(\frac{x}{X}\right)^{(1+1 / f)}\right\}
\end{aligned}
$$

\subsection{5. 使用料累計 $\boldsymbol{L}(\boldsymbol{x})$}

\section{(1) スクラップ価格を零とした場合}

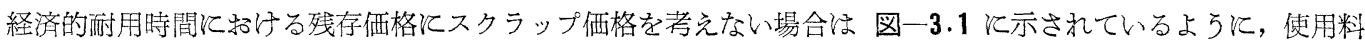
の累計は原点から $R(x)$ 曲線切線を引き，その切点が経済的耐用時間 $X$ であることから (3.2) 式を用い

$$
L(x)=\{R(X)+P\}\left(\frac{x}{X}\right)=(1+f)\left(\frac{x}{X}\right) \cdot P
$$

(2) 経済的耐用時間に和ける残存価格がスクラップ価格となる場合 $\left(S(X)=P_{S}\right)$

図一3.3 呿よび (3.9) 式の関係より

$$
L(x)=\left\{R(X)+P-P_{S}\right\} \cdot\left(\frac{x}{X}\right)=\left(1+f-\frac{P_{S}}{P}\right)\left(\frac{x}{X}\right) \cdot P
$$

(3) 経济的耐用時間より短かい $X_{S}$ 時間において残存価格がスクラップ価格となる場合 $\left(S\left(X_{S}\right)=P_{S}, X_{S}<X\right)$ $x<X_{S}$ の範囲では，図-3.4 の関係より (3.9) 式に同じとなる。 $x>X_{S}$ の範囲では同様にして

$$
\begin{aligned}
L(x) & =\left\{R(X)+P-L\left(X_{S}\right)-P_{S}\right\}\left(\frac{x-X_{S}}{X-X_{S}}\right) \\
& =P\left\{(1+f)\left(1-\frac{X_{S}}{X}\right)-\frac{P_{S}}{P}\right\}\left(\frac{x-X_{S}}{X-X_{S}}\right)
\end{aligned}
$$

3.2.6. 時間当门使用料 $\boldsymbol{l}(\boldsymbol{x})$

建設機械の耐用限度を時間数で定める機械については，使用料についても時間当り使用料を定めて物く必要が

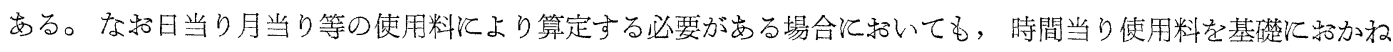
ばならない。時間当り使用料は使用料䍗計を使用時間で除したもので機械の新泪の別により，使用料は変化しな 
いるのとすう。

$$
l(x)=\frac{L(x)}{x}
$$

従つて (3.9) 式の使用料累計汶対する時間当り使用料は次のよ5飞表わされる。

$$
l(x)=(1+f) \cdot \frac{P}{X}
$$

(3.10) 式については同様汇

$$
l(x)=\left(1+f-\frac{P_{S}}{P}\right) \cdot \frac{P}{X}
$$

\section{3. 修理費のみ物価指数の变動を考慮した場合の使用料の算定}

\subsection{1. 修理費，経済的耐用時間等の基本的関係}

建設機械に対する物価が変動する場合，修理費についてのみ物価指数の変動を考慮して使用料を算定する必要 が起る。い屯，毎年修理費の物価指数が変動するるの とし, 購入価格を $P$, 各年次湉ける修理費の物価指 数率, 経済的耐用時間执よび年標準運転時間を表一

3.1 のよう定める。

各年次の区分々説明の都合上定めたので，実際にほ 物価の変動を考虑する期間 (時間) 飞区切つて同様な

\begin{tabular}{|c|c|c|c|}
\hline 分 & $\begin{array}{l}\text { 修理費数 率 } \\
\text { 価指 }\end{array}$ & 経済的利用時間 & $\begin{array}{l}\text { 各年次未までの } \\
\text { 運 転 時 }\end{array}$ \\
\hline $\begin{array}{l}\text { 第 } 1 \text { 年次 } \\
\text { (購入年次) }\end{array}$ & $\alpha_{1}(=1)$ & $X_{1}$ & $N x_{1}$ \\
\hline 第 2 年次 & $\alpha_{2}$ & $X_{2}$ & $N x_{2}$ \\
\hline 第 3 年次 & $\alpha_{3}$ & $X_{3}$ & $N x_{3}$ \\
\hline$\vdots$ & $\vdots$ & $\vdots$ & $\vdots$ \\
\hline 第 $n$ 年次 & $\alpha_{n}$ & $X_{n}$ & $N x_{n}$ \\
\hline
\end{tabular}
方法で行壳ばよい。

以上の関係から各年次別の使用料括よび修理費の関

係を図示すると図一 3.5 のようである。図一 3.5 は 3 年間で経済的耐用時間に達する場合で，使用料の累計直線 は購入年次に括いては $L_{1}(x)$ の直線で示され， 0 点より $a$ 点に至り，第 2 年次に括いては $L_{2}(x)$ の直線で示さ れ, $a$ 点から, $d$ 点を通る $R_{2}{ }^{\prime}(x)$ 曲線汇並行な曲線汇 引いた切線上定 $b$ 点汪至り, 第 3 年次に括いては同様に $L_{3}(x)$ の直線で示され, $b$ 点 から, $e$ 点を通る $R_{3}{ }^{\prime}(x)$ 曲 線湴行汇引いた切線上を $c$ 点任至る 3 つの組合わされた 直線で示される。

修理費の䍗計曲線飞同様儿 $d$ 招よび $e$ の 2 点て変曲して $c$ で $b-c$ 直線が接する $R_{1}(x)$ と $R_{2}{ }^{\prime}(x), R_{3}{ }^{\prime}(x)$ 飞それぞれ 並行な $R_{2}(x), R_{3}(x)$ の 3 の組合わされた曲線で示され る。

物価指数率凹が異なる場合 のそれぞれの修理費累計曲線 $R_{1}(x), R_{2}{ }^{\prime}(x), R_{3}{ }^{\prime}(x) \cdots \cdots$ $R_{n}{ }^{\prime}(x)$ の経済的耐用時間を $X_{1}, X_{2}{ }^{\prime} X_{3}{ }^{\prime} \cdots X_{n}{ }^{\prime}$ とし $\alpha_{2}{ }^{\prime} f$, $\alpha_{3}{ }^{\prime} f \cdots \alpha_{n}{ }^{\prime} f$ ख $X_{2}{ }^{\prime}, X_{3}{ }^{\prime} \cdots X_{n}{ }^{\prime}$

図-3.5

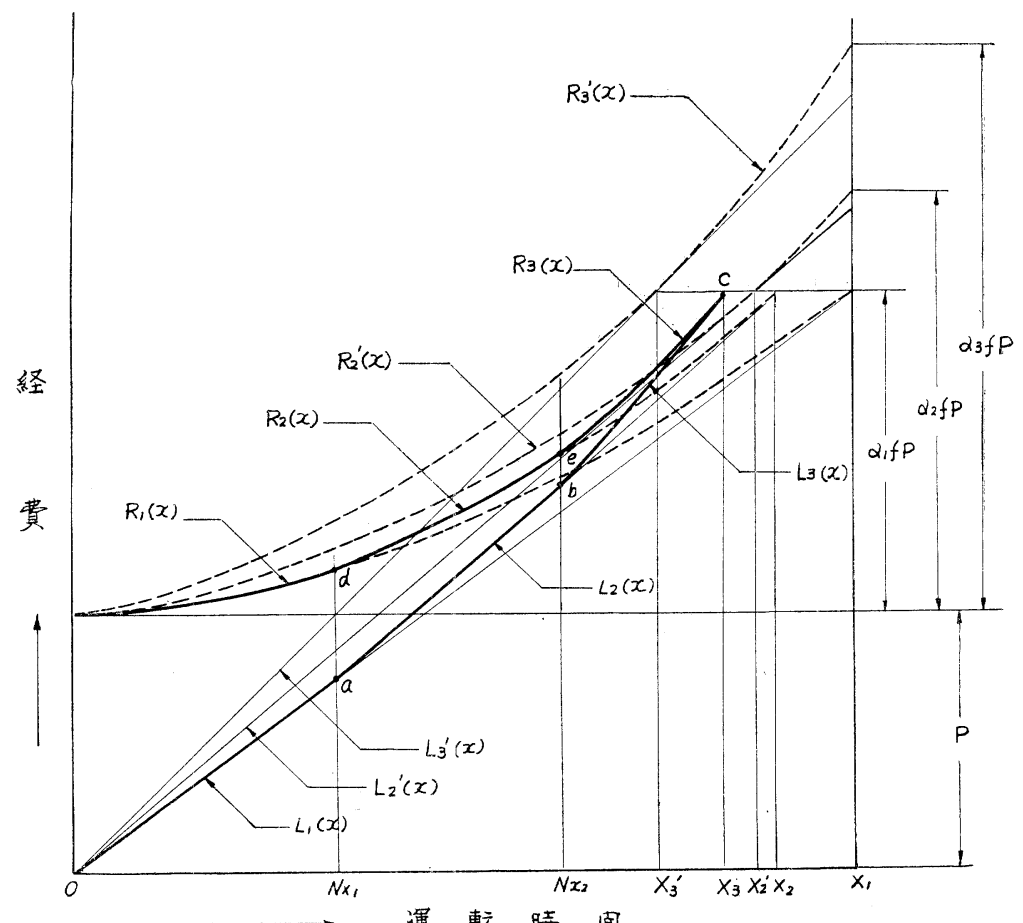

そ扮ける修理費審計の $P$ 亿対する割合とすると $R_{1}(x), R_{2}{ }^{\prime}(x), R_{3}{ }^{\prime}(x) \cdots R_{n}{ }^{\prime}(x)$ は (3.5) 式により次のごとく表 わされる。

$$
R_{1}(x)=\alpha_{1} \cdot f \cdot P \cdot\left(\frac{x}{X_{1}}\right)^{\left(1+\frac{1}{\alpha_{1} \cdot f}\right)}
$$




$$
\begin{aligned}
& R_{2}{ }^{\prime}(x)=\alpha_{2}{ }^{\prime} \cdot f \cdot P \cdot\left(\frac{x}{X_{2}{ }^{\prime}}\right)^{\left(1+\frac{1}{\alpha_{2^{\prime} \cdot f}}\right)} \ldots \ldots . . \\
& R_{3}{ }^{\prime}(x)=\alpha_{3}{ }^{\prime} \cdot f \cdot P \cdot\left(\frac{x}{X_{3}{ }^{\prime}}\right)^{\left(1+\frac{1}{\alpha_{3^{\prime} \cdot f}}\right)} \\
& R_{n}{ }^{\prime}(x)=a_{n}{ }^{\prime} \cdot f \cdot P \cdot\left(\frac{x}{X_{n}{ }^{\prime}}\right)^{\left(1+\frac{1}{\alpha_{n^{\prime}} \cdot f}\right)}
\end{aligned}
$$

次に (3.15) ( (3.17) 式恬和る $\alpha_{2}{ }^{\prime}, \alpha_{3}{ }^{\prime} \cdots \alpha_{n}{ }^{\prime}$ と $\alpha_{1}$ との関係抢よび $X_{2}{ }^{\prime}, X_{3}{ }^{\prime} \cdots X_{n}{ }^{\prime}$ と $X_{1}$ との関係を求め る。すなわち図一3.6 亿招いて物価指数率 $\alpha_{1}$ の場合 の修理費累計曲線を $R_{1}(x), \alpha_{2}$ の場合を $R_{2}{ }^{\prime}(x)$ とし, それぞれの経済的耐用時間を $X_{1}, X_{2}{ }^{\prime}$ とする。な特 $R_{2}{ }^{\prime}(x)$ の $X_{2}{ }^{\prime}$ 飞拾ける修理費累計の $P$ 亿対する割合 は $\alpha_{2}^{\prime} f$ であるから，(3.14), (3.15) 式により $R_{1}\left(X_{2}{ }^{\prime}\right)$ 把よび $R_{2}{ }^{\prime}\left(X_{2}{ }^{\prime}\right)$ 求めると,

$$
\begin{aligned}
& R_{1}\left(X_{2}{ }^{\prime}\right)=\alpha_{1} \cdot f \cdot P\left(\frac{X_{2}{ }^{\prime}}{X_{1}}\right)^{\left(1+\frac{1}{\alpha_{1} \cdot f}\right)} \\
& R_{2}{ }^{\prime}\left(X_{2}{ }^{\prime}\right)=\alpha_{2}{ }^{\prime} \cdot f \cdot P \\
& R_{1}\left(X_{2}{ }^{\prime}\right) \cdot \frac{\alpha_{2}}{\alpha_{1}}=R_{2}{ }^{\prime}\left(X_{2}{ }^{\prime}\right) \text { の関係から } \\
& \alpha_{1} \cdot \alpha_{2} \cdot f \cdot P\left(\frac{X_{2}{ }^{\prime}}{X_{1}}\right)^{\left(1+\frac{1}{\alpha_{1} \cdot f}\right)}=\alpha_{1} \cdot \alpha_{2}{ }^{\prime} \cdot f \cdot P
\end{aligned}
$$

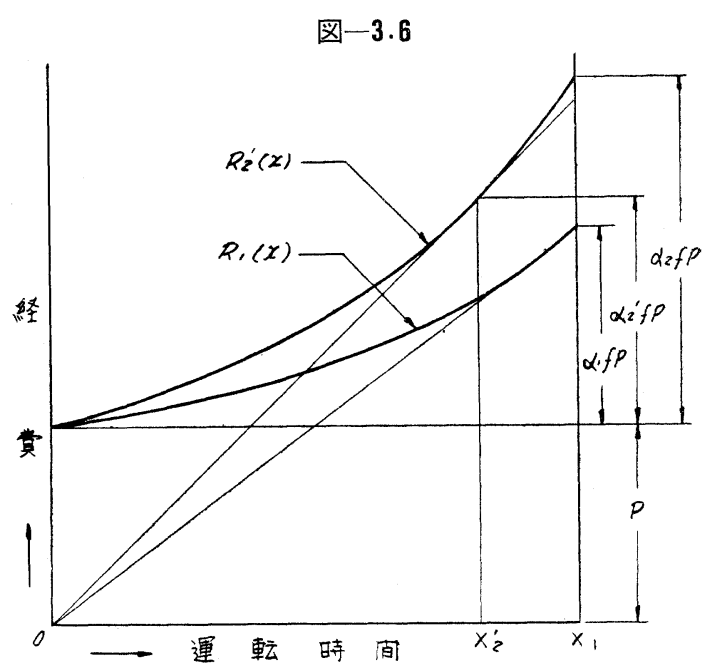

従つて $\quad\left(\frac{X_{2}^{\prime}}{X_{1}}\right)^{\left(1+\frac{1}{\alpha_{1} \cdot f}\right)}=\frac{\alpha_{2}{ }^{\prime}}{\alpha_{2}}$

また同様にして $R_{1}\left(X_{1}\right)$ 招よび $R_{2}{ }^{\prime}\left(X_{1}\right)$ を求めると，

$$
\begin{aligned}
& R_{1}\left(X_{1}\right)=\alpha_{1} \cdot f \cdot P \\
& R_{2}{ }^{\prime}\left(X_{1}\right)=\alpha_{2}{ }^{\prime} \cdot f \cdot P\left(\frac{X_{1}}{X_{2}}\right)^{\left(1+\frac{1}{\alpha_{2^{\prime} \cdot f f}}\right)} \\
& R_{1}\left(X_{1}\right) \cdot\left(\frac{\alpha_{2}}{\alpha_{1}}\right)=R_{2}{ }^{\prime}\left(X_{1}\right) \text { の関係から } \\
& \alpha_{1} \cdot \alpha_{2} \cdot f \cdot P=\alpha_{1} \cdot \alpha_{2} \cdot f \cdot P \cdot\left(\frac{X_{1}}{X_{2}{ }^{\prime}}\right)^{\left(1+\frac{1}{\alpha_{2} \cdot \cdot f}\right)}
\end{aligned}
$$

従つて $\left(\frac{X_{2}{ }^{\prime}}{X_{1}}\right)^{\left(1+\frac{1}{\alpha_{2} \cdot f}\right)}=\frac{\alpha_{2}{ }^{\prime}}{\alpha_{2}}$

故に (3.18)，(3.19) 式により

$$
\begin{aligned}
& \alpha_{2}{ }^{\prime}=\alpha_{1} \\
& \left(\frac{X_{2}{ }^{\prime}}{X_{1}}\right)^{\left(1+\frac{1}{\alpha_{1} \cdot f}\right)}=\frac{\alpha_{1}}{\alpha_{2}}
\end{aligned}
$$

3.3.2. 使用料累計

使用料の算定式を求めるとは, 先に修理費累計の算定式を求める必要がある。修理費は図一 3.5 の関係から

$$
\begin{aligned}
& R_{1}(x)=\alpha_{1} \cdot f \cdot P \cdot\left(\frac{x}{X_{1}}\right)^{\left(1+\frac{1}{\alpha_{1} \cdot j}\right)} \\
& R_{2}(x)=R_{2}{ }^{\prime}(x)-R_{2}{ }^{\prime}\left(N x_{1}\right)+R_{1}\left(N x_{1}\right) \\
& =f \cdot P\left\{\alpha_{2}{ }^{\prime} \cdot\left(\frac{x}{X_{2}^{\prime}}\right)^{\left(1+\frac{1}{\alpha_{2^{\prime} \cdot J^{\prime}}}\right)}-\alpha_{2}{ }^{\prime} \cdot\left(\frac{N x_{1}}{X_{2}^{\prime}}\right)^{\left(1+\frac{1}{\alpha_{2} \cdot^{\prime} f}\right.}\right\}+R_{1}\left(N x_{1}\right) \\
& =\alpha_{2} \cdot f \cdot P\left\{\left(\frac{x}{X_{1}}\right)^{\left(1+\frac{1}{\alpha_{1} \cdot f}\right)}-\left(\frac{N x_{1}}{X_{1}}\right)^{\left(1+\frac{1}{\alpha_{1} \cdot f}\right.}\right\}+R_{1}\left(N x_{1}\right) \\
& R_{3}(x)=R_{3}{ }^{\prime}(x)-R_{3}{ }^{\prime}\left(N x_{2}\right)+R_{2}\left(N x_{2}\right) \\
& =\alpha_{3} \cdot f \cdot P\left\{\left(\frac{x}{X_{1}}\right)^{\left(1+\frac{1}{\alpha_{1} \cdot f}\right)}-\left(\frac{N x_{2}}{X_{1}}\right)^{\left(1+\frac{1}{\alpha_{1} \cdot f}\right)}\right\}+R_{2}\left(N x_{2}\right)
\end{aligned}
$$




$$
\begin{aligned}
R_{n}(x) & =R_{n}{ }^{\prime}(x)-R_{n}{ }^{\prime}\left(N x_{n-1}\right)+R_{n-1}\left(N x_{n-1}\right) \\
& =\alpha_{n} \cdot f \cdot P\left\{\left(\frac{x}{X_{1}}\right)^{\left(1+\frac{1}{\alpha_{1} \cdot f}\right)}-\left(\frac{N x_{n-1}}{X_{1}}\right)^{\left(1+\frac{1}{\alpha_{1} \cdot f}\right)}\right\}+R_{n-1}\left(N x_{n-1}\right)
\end{aligned}
$$

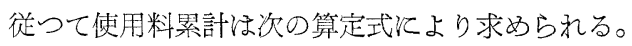

(第 1 年次)

$$
L_{1}(x)=\left(1+\alpha_{1} f\right) \cdot\left(\frac{x}{X_{1}}\right) \cdot P
$$

(第 2 年次)

$$
L_{2}(x)=\left\{R_{2}\left(X_{2}\right)+P-L_{1}\left(N x_{1}\right)\right\}\left(\frac{x-N x_{1}}{X_{2}-N x_{1}}\right)+L_{1}\left(N x_{1}\right)
$$

(第 3 年次)

$$
L_{3}(x)=\left\{R_{3}\left(X_{3}\right)+P-L_{2}\left(N x_{2}\right)\right\}\left(\frac{x-N x_{2}}{X_{3}-N x_{2}}\right)+L_{2}\left(N x_{2}\right)
$$

(第 $n$ 年次)

$$
L_{n}(x)=\left\{R_{n}\left(X_{n}\right)+P-L_{n-1}\left(N x_{n-1}\right)\right\}\left(\frac{x-N x_{n-1}}{X_{n}-N x_{n-1}}\right)+L_{n-1}\left(N x_{n-1}\right)
$$

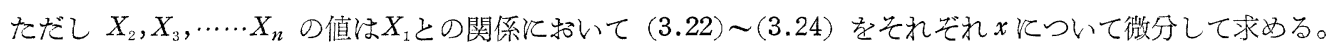

$$
\begin{aligned}
\left|\frac{d R_{2}(x)}{d x}\right|_{x=x_{2}} & =\alpha_{2} \cdot f \cdot P\left(1+\frac{1}{\alpha_{1} \cdot f}\right)\left(\frac{X_{2}}{X_{1}}\right)^{\left(1+\frac{1}{\alpha_{1} \cdot f}\right) \frac{1}{X_{2}}} \\
& =\frac{R_{2}\left(X_{2}\right)+P-L_{1}\left(N x_{1}\right)}{X_{2}-N x_{1}}
\end{aligned}
$$

上式より

$$
\begin{aligned}
& X_{2}=X_{1} \cdot \sqrt[\left(1+\frac{1}{\alpha_{1} \cdot f}\right)]{\frac{P-\alpha_{2} \cdot f \cdot P\left(\frac{N x_{1}}{X_{1}}\right)^{\left(1+\frac{1}{\alpha_{1} \cdot f}\right)}+R_{1}\left(N x_{1}\right)-L_{1}\left(N x_{1}\right)}{P\left\{\frac{\alpha_{2}}{\alpha_{1}}-\left(-\frac{N x_{1}}{X_{2}}\right)\left(\alpha_{2} f+\frac{\alpha_{2}}{\alpha_{1}}\right)\right\}}} \\
& X_{3}=X_{1} \cdot\left(1+\frac{1}{\alpha_{1} \cdot f}\right) \sqrt{\frac{P-\alpha_{3} \cdot f \cdot P\left(\frac{N x_{2}}{X_{1}}\right)^{\left(1+\frac{1}{\alpha_{1} \cdot f}\right)}+R_{2}\left(N x_{2}\right)-L_{2}\left(L x_{2}\right)}{P\left\{\frac{\alpha_{3}}{\alpha_{1}}-\left(\frac{N x_{2}}{X_{3}}\right)\left(\alpha_{3} f+\frac{\alpha_{3}}{\alpha_{1}}\right)\right\}}} \\
& X_{n}=X_{1} \cdot\left(1+\frac{1}{\alpha_{1} \cdot \mathcal{J}}\right) \sqrt{\frac{\left.P-\alpha_{n} \cdot f \cdot P\left(\frac{N x_{n-1}}{X_{1}}\right)^{\left(1+\frac{1}{\alpha_{1} \cdot f}\right.}\right)+R_{n-1}\left(N x_{n-1}\right)-L_{n-1}\left(N x_{n-1}\right)}{P\left\{\frac{\alpha_{n}}{\alpha_{1}}-\left(\frac{N x_{n-1}}{X_{n}}\right)\left(\alpha_{n} \cdot f+\frac{\alpha_{n}}{\alpha_{1}}\right)\right\}}}
\end{aligned}
$$

この $X_{2}, X_{3}, \cdots \cdots X_{n}$ を求めるには図式解法をたは試算による。

\subsection{3. 時間当使用料 $\boldsymbol{l}(\boldsymbol{x})$}

(3.25) ( (3.28) 式より次のごとく求められる。

（第 1 年次）

$$
l_{1}(x)=\left(1+\alpha_{1} \cdot f\right) \frac{P}{X_{1}}
$$

(第 2 年次)

$$
l_{2}(x)=\left\{R_{2}\left(X_{2}\right)+P-L_{1}\left(N x_{1}\right)\right\} \frac{1}{X_{2}-N x_{1}}
$$

(第 3 年次)

$$
l_{3}(x)=\left\{R_{3}\left(X_{3}\right)+P-L_{2}\left(N x_{3}\right)\right\} \frac{1}{X_{3}-N x_{2}}
$$

（第 $n$ 年次）

$$
l_{n}(x)=\left\{R_{n}\left(X_{n}\right)+P-L_{n-1}\left(N x_{n-1}\right)\right\} \frac{1}{X_{n}-N x_{n-1}}
$$




\section{4. 購入価格を評価替した場合の使用料の算定}

\subsection{1. 修理費, 経済的耐用時間等の基本的関係}

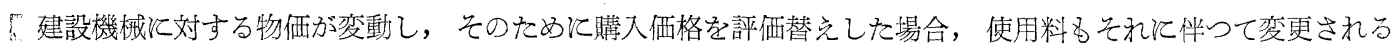
ベきである。

いま，購入佂格を $P$ とし，評価ごとの評価指数率 (修理費の物価指数率もこれに同じとする) 経済的耐 用時間, 次の評価までの運転時間を表一 3.2 のように 定める。

以上の関係から各評価後の使用料抒よび修理費の関 係を図示すると図一3.7 のような関係となる。図一 3.7 は 3 回の評価替で経済的耐用時間飞達する場合で

\begin{tabular}{|c|c|c|c|}
\hline \multicolumn{4}{|c|}{ 表一3.2 } \\
\hline 分 & 評価指数率 & 経斎的耐用封間 & $\begin{array}{l}\text { 次の評価末での } \\
\text { 運転 時 }\end{array}$ \\
\hline 購 入 時 & $\alpha_{1}(=1)$ & $X_{1}$ & $M x_{1}$ \\
\hline 1 次評価 & $\alpha_{2}$ & $X_{2}$ & $M x_{2}$ \\
\hline 再 評 価 & $a_{3}$ & $X_{3}$ & $M x_{3}$ \\
\hline$\ldots$ & $\ldots$ & $\cdots$ & $\ldots$ \\
\hline 最終評価 & $\alpha_{n}$ & $X_{n}$ & $M x_{n}$ \\
\hline
\end{tabular}

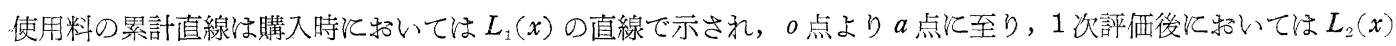

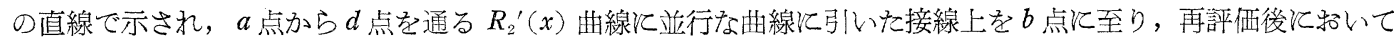

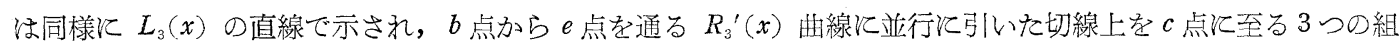
合わされた直線で示される。

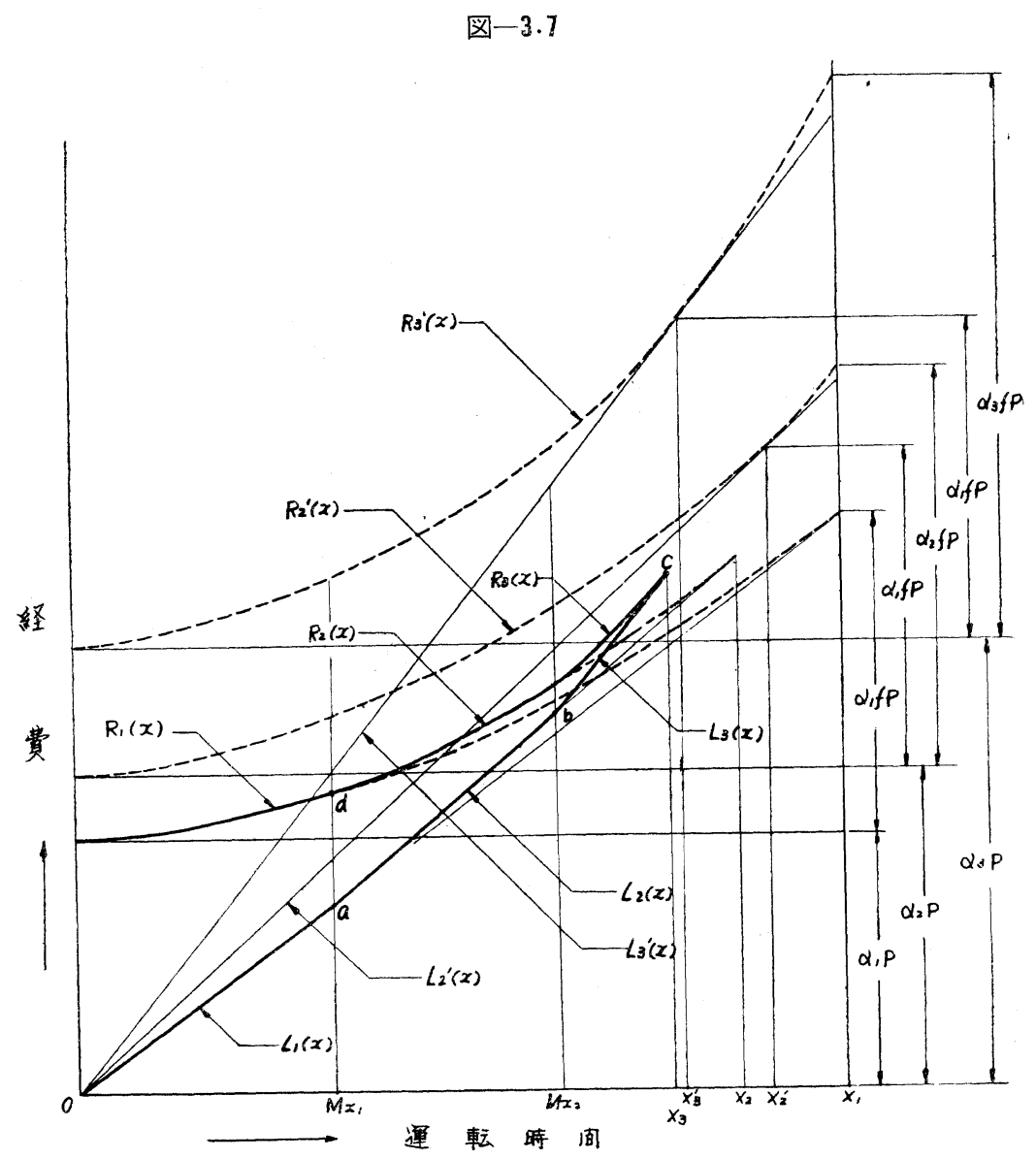

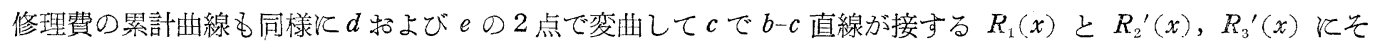
れぞれ並行な $R_{2}(x)$ 物よび $R_{3}(x)$ の 3 の組合わされた曲線で示される。

物価指数率 $\propto$ が異なる場合のそれぞれの修理費累計曲線 $R_{1}(x), R_{2}{ }^{\prime}(x), R_{3}{ }^{\prime}(x) \cdots \cdots R_{n}{ }^{\prime}(x)$ の経済的耐用時間を $X_{1}, X_{2}{ }^{\prime}, X_{3}{ }^{\prime} \cdots \cdots X_{n}{ }^{\prime}$ とし $\alpha_{2}{ }^{\prime} f, \alpha_{3}{ }^{\prime} f \cdots \cdots \alpha_{n}{ }^{\prime} f$ は $X_{2}{ }^{\prime}, X_{3}{ }^{\prime}, \cdots \cdots X_{n}{ }^{\prime}$ V括外る修理費累計の $P$ 亿対する割合とすると $R_{1}(x), R_{2}{ }^{\prime}(x), R_{3}{ }^{\prime}(x) \cdots \cdots R_{n}{ }^{\prime}(x)$ は次式で表わされる。 


$$
\begin{aligned}
& R_{1}(x)=\alpha_{1} \cdot f \cdot P\left(\frac{x}{X_{1}}\right)^{\alpha_{1}\left(1+\frac{1}{f}\right)} \ldots \\
& R_{2}{ }^{\prime}(x)=\alpha_{2}{ }^{\prime} \cdot f \cdot P\left(\frac{x}{X_{2}^{\prime}}\right)^{\alpha_{2^{\prime}}\left(1+\frac{1}{f}\right)} \ldots \\
& R_{3}{ }^{\prime}(x)=\alpha_{3}{ }^{\prime} \cdot f \cdot P\left(\frac{x}{X_{3}{ }^{\prime}}\right)^{\alpha_{3^{\prime}}\left(1+\frac{1}{f}\right)} \ldots \\
& R_{n}{ }^{\prime}(x)=\alpha_{n}{ }^{\prime} \cdot f \cdot P\left(\frac{x}{X_{n}{ }^{\prime}}\right)^{\alpha_{n^{\prime}}\left(1+\frac{1}{f}\right)}
\end{aligned}
$$

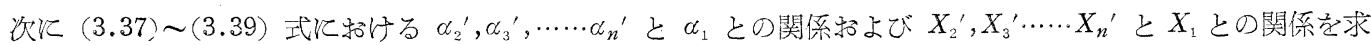

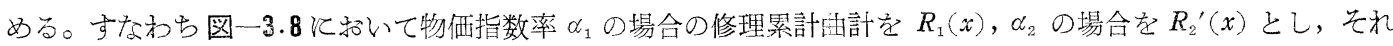

図-3.8

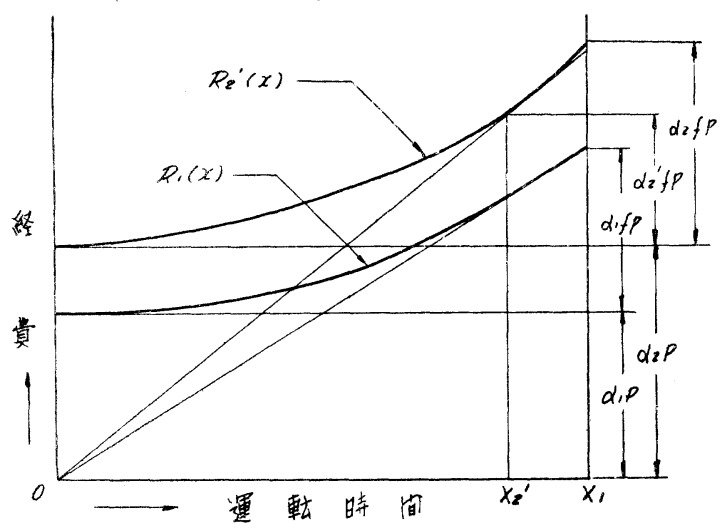

また同様として $R_{1}\left(X_{1}\right)$ 洛よび $R_{2}{ }^{\prime}\left(X_{1}\right)$ を求めると

$R_{1}\left(X_{1}\right)=\alpha_{1} \cdot f \cdot P$

$R_{2}{ }^{\prime}\left(X_{1}\right)=\alpha_{2}{ }^{\prime} \cdot f \cdot P \cdot\left(\frac{X_{1}}{X_{2}{ }^{\prime}}\right)^{\alpha_{2}{ }^{\prime} \cdot\left(1+\frac{1}{f}\right)}$

$R_{1}\left(X_{1}\right) \cdot \frac{\alpha_{2}}{\alpha_{1}}=R_{2}{ }^{\prime}\left(X_{1}\right)$ の関係方ら

$\alpha_{1} \cdot \alpha_{2} \cdot f \cdot P=\alpha_{1} \cdot \alpha_{2}^{\prime} \cdot f \cdot P\left(\frac{X_{1}}{X_{2}^{\prime}}\right)^{\alpha_{2}^{\prime} \cdot\left(1+\frac{1}{f}\right)}$

ぞれの経済的耐用時間を $X_{1}, X_{2}^{\prime}$ とする。な゙和 $R_{2}{ }^{\prime}(x)$ の $X_{2}^{\prime}$ 飞扮沙る修理費累計の $P$ 飞対する 割合は $\alpha_{2}^{\prime} \cdot f$ であるから (3.36)，(3.37) 式より $R_{1}\left(X_{2}{ }^{\prime}\right)$ 呿よび $R_{2}{ }^{\prime}\left(X_{2}{ }^{\prime}\right)$ を求めると

$$
\begin{aligned}
& R_{1}\left(X_{2}^{\prime}\right)=\alpha_{1} \cdot f \cdot P\left(\frac{X_{2}{ }^{\prime}}{X_{1}}\right)^{\alpha_{1} \cdot\left(1+\frac{1}{f}\right)} \\
& R_{2}{ }^{\prime}\left(X_{2}{ }^{\prime}\right)=\alpha_{2}{ }^{\prime} \cdot f \cdot P \\
& R_{1} \cdot\left(X_{2}{ }^{\prime}\right) \cdot \frac{\alpha_{2}}{\alpha_{1}}=R_{2}{ }^{\prime}\left(X_{2}{ }^{\prime}\right) \quad \text { の関係办 } 5 \\
& \alpha_{1} \cdot \alpha_{2} \cdot f \circ P\left(\frac{X_{2}{ }^{\prime}}{X_{1}}\right)^{\alpha_{1}\left(1+\frac{1}{f}\right)}=\alpha_{1} \cdot \alpha_{2}{ }^{\prime} \cdot f \cdot P
\end{aligned}
$$

従つて

$$
\left(\frac{X_{2}^{\prime}}{X_{1}}\right)^{\alpha_{1}\left(1+\frac{1}{f}\right)}=\frac{\alpha_{2}^{\prime}}{\alpha_{1}}
$$

従つて

$$
\left(\frac{X_{2}^{\prime}}{X_{1}}\right)^{\alpha_{2}{ }^{\prime}\left(1+\frac{1}{f}\right)}=\frac{\alpha_{2}^{\prime}}{\alpha_{2}}
$$

故に (3.40)，(3.41) 式より

$$
\begin{aligned}
& \alpha_{2}{ }^{\prime}=\alpha_{1} \\
& \left(\frac{X_{2}{ }^{\prime}}{X_{1}}\right)^{\alpha_{1}} \cdot\left(1+\frac{1}{f}\right)=\frac{\alpha_{1}}{\alpha_{2}}
\end{aligned}
$$

3.4.2. 使用料累計

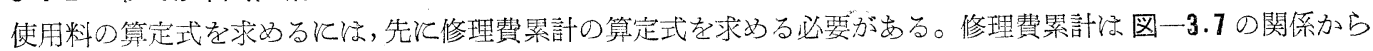

$$
\begin{aligned}
& R_{1}(x)=\alpha_{1} \cdot f \cdot P\left(\frac{x}{X_{1}}\right)^{\alpha_{1} \cdot\left(1+\frac{1}{f}\right)} \\
& R_{2}(x)=R_{2}{ }^{\prime}(x)-R_{2}{ }^{\prime}\left(M x_{1}\right)+R_{1}\left(M x_{1}\right)-\left(\alpha_{2}-\alpha_{1}\right) \cdot P \\
& =\alpha_{2} \cdot f \cdot P\left\{\left(\frac{x}{X_{1}}\right)^{\alpha_{1} \cdot\left(1+\frac{1}{f}\right)}-\left(\frac{M x_{1}}{X_{2}}\right)^{\alpha_{1} \cdot\left(1+\frac{1}{f}\right)}\right\}+R_{1}\left(M x_{1}\right)-\left(\alpha_{2}-\alpha_{1}\right) P \\
& R_{3}(x)=R_{3}{ }^{\prime}(x)-R_{3}{ }^{\prime}\left(M x_{1}\right)+R_{2}\left(M x_{2}\right)-\left(\alpha_{3}-\alpha_{1}\right) P
\end{aligned}
$$




$$
\begin{aligned}
& =\alpha_{3} \circ f \cdot P\left\{\left(\frac{x}{X_{1}}\right)^{\alpha_{1}\left(1+\frac{1}{f}\right)}-\left(\frac{M x_{2}}{X_{1}}\right)^{\alpha_{1} \cdot\left(1+\frac{1}{f}\right)}\right\}+R_{2}\left(M x_{2}\right)-\left(\alpha_{3}-\alpha_{1}\right) P \\
& R_{n}(x)=R_{n}{ }^{\prime}(x)-R_{n}{ }^{\prime}\left(M x_{n-1}\right)+R_{n-1}\left(M x_{n-1}\right)-\left(\alpha_{n}-\alpha_{1}\right) \cdot P \\
& =\alpha_{n} \cdot f \cdot P\left\{\left(\frac{x}{X_{1}}\right)^{\alpha_{1} \cdot\left(1+\frac{1}{f}\right)}-\left(\frac{M x_{n-1}}{X_{1}}\right)^{\alpha_{1}\left(1+\frac{1}{f}\right)}\right\}+R_{n-1}\left(M x_{n-1}\right)-\left(\alpha_{n}-\alpha_{1}\right) \cdot P
\end{aligned}
$$

従つて使用料累計は次に示す算定式により求められる。

(購 入 時)

$$
L_{1}(x)=\alpha_{1}(1+f)\left(\frac{x}{X_{1}}\right) P
$$

( 1 次評価後)

$$
\begin{aligned}
& L_{2}(x)=\left\{R_{2}\left(X_{2}\right)+\left(\alpha_{2}-\alpha_{1}\right) P+\alpha_{1} P-L_{1}\left(M x_{1}\right)\right\}\left(\frac{x-M x_{1}}{X_{2}-M x_{1}}\right)+L_{1}\left(M x_{1}\right) \\
& =\left\{R_{2}\left(X_{2}\right)+\alpha_{2} \cdot P-L_{1}\left(M x_{1}\right)\right\}\left(\frac{x-M x_{1}}{X_{2}-M x_{1}}\right)+L_{1}\left(M x_{1}\right)
\end{aligned}
$$

(再評価後)

$$
L_{3}(x)\left\{R_{3}\left(X_{3}\right)+\alpha_{3} \cdot P-L_{2}\left(M x_{2}\right)\right\}\left(\frac{x-M x_{2}}{X_{3}-M x_{2}}\right)+L_{2}\left(M x_{2}\right)
$$

(最終評価後)

$$
L_{n}(x)=\left\{R_{n}\left(X_{n}\right)+\alpha_{n} \cdot P-L_{n-1}\left(M x_{n-1}\right)\right\}\left(\frac{x-M x_{n-1}}{X_{n}-M x_{n-1}}\right)+L_{n-1}\left(M x_{n-1}\right)
$$

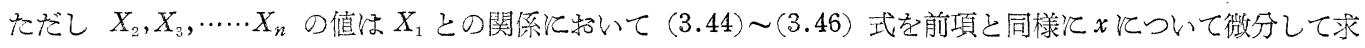
めらと次のようになる。

$$
\begin{aligned}
& X_{2}=X_{1} \cdot{ }^{\alpha_{1}\left(1+\frac{1}{f}\right)} \sqrt{\frac{\alpha_{2} P-\alpha_{2} \cdot f \cdot P\left(\frac{M x_{1}}{X_{1}}\right)^{\alpha_{1}\left(1+\frac{1}{f}\right)}+R_{1}\left(M x_{1}\right)-L_{1}\left(M x_{1}\right)}{f \cdot P\left\{\alpha_{1}, \alpha_{2}\left(1+\frac{1}{f}\right)\left(1-\frac{M x_{1}}{X_{2}}\right)-\alpha_{2}\right\}}} \\
& X_{3}=X_{1} \cdot \alpha_{1}\left(1+\frac{1}{f}\right) \sqrt{\frac{\alpha_{3} \cdot P-\alpha_{3} \cdot f \cdot P\left(\frac{M x_{2}}{X_{2}}\right)^{\alpha_{1}\left(1+\frac{1}{f}\right)}+R_{2}\left(M x_{2}\right)-L_{2}\left(M x_{2}\right)}{f \cdot P\left\{\alpha_{1} \alpha_{3}\left(1+\frac{1}{f}\right)\left(1-\frac{M x_{2}}{X_{3}}\right)-\alpha_{3}\right\}}} \\
& X_{n}=X_{1} \cdot \alpha_{1}\left(1+\frac{1}{f}\right) \sqrt{\frac{\alpha_{n} \cdot P-\alpha_{n} \cdot f \cdot P\left(\frac{M x_{n-1}}{X_{1}}\right)^{\alpha_{1}\left(1+\frac{1}{f}\right)}+R_{n-1}\left(M x_{n-1}\right)-L_{n-1}\left(M x_{n-1}\right)}{f \circ P\left\{\alpha_{1} \alpha_{n}\left(1+\frac{1}{f}\right)\left(1-\frac{M x_{n-1}}{X_{n}}\right)-\alpha_{n}\right\}}}
\end{aligned}
$$

この $X_{2}, X_{3}, \cdots \cdots X_{n}$ を求めるには図式解法または試算による。

\subsection{3. 時間当り使用料}

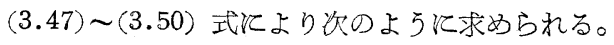

(購 入 時)

$$
l_{1}(x)=\alpha_{1}(1+f) \frac{P}{X_{1}}
$$

( 1 次評価後)

$$
l_{2}(x)=\left\{R_{2}\left(X_{2}\right)+\alpha_{2} \cdot P-L_{1}\left(M x_{1}\right)\right\} \frac{1}{X_{2}-M x_{1}}
$$

(再評価後)

$$
l_{3}(x)=\left\{R_{3}\left(X_{3}\right)+\alpha_{3} \cdot P-L_{2}\left(M x_{2}\right)\right\} \frac{1}{X_{3}-M x_{2}}
$$


(最終評価後)

$$
l_{n}(x)=\left\{R_{n}\left(X_{n}\right)+\alpha_{n} \cdot P-L_{n-1}\left(M x_{n-1}\right)\right\} \frac{1}{X_{n}-M x_{n-1}}
$$

\section{5. 中古機械の使用料の算定}

運転時間累計 $x_{1}$ の機械（ただし整備が完全にされているもの）を購入価格 $S^{\prime}\left(x_{1}\right)$ で入手したとすると， $x_{1}$ 橸 間使用した機械の残存価格 $S_{1}\left(x_{1}\right)$ は (3.7) 式より,

$$
S\left(x_{1}\right)=P \cdot\left\{(1+f)\left(\frac{x_{1}}{X}\right)^{\left(1+\frac{1}{f}\right)}-(1+f)\left(\frac{x_{1}}{X}\right)\right\}
$$

(3.58) 式と同じ残存洒格率で残存洒格 $S^{\prime}(x)$ となる新品購 入価格を $P^{\prime}$ とすると（図一 3.9 参照）

$$
S^{\prime}\left(x_{1}\right)=P^{\prime}\left\{(1+f)\left(\frac{x_{1}}{X}\right)^{\left(1+\frac{1}{f}\right)}-(1+f)\left(\frac{x_{1}}{X}\right)\right\}
$$

従つて

$$
P^{\prime}=P \frac{S^{\prime}\left(x_{1}\right)}{S\left(x_{1}\right)}
$$

中古機械としての使用料累計 $L^{\prime}(x)$ はスクラップ洒格を零 とすれば

$$
L_{1}^{\prime}(x)=\left(P^{\prime}+f \cdot P\right)\left(\frac{x}{X}\right)
$$

すなわり

$$
L_{1}{ }^{\prime}(x)=\left\{\frac{S^{\prime}\left(x_{1}\right)}{S\left(x_{1}\right)}+f\right\}\left(\frac{x}{X}\right) \cdot P .
$$

スクラップ洒格 $P_{s}$ を計算飞入れた場合 $\left(S(X)=P_{s}\right)$ は

$$
L^{\prime}(x)=\left\{\frac{S^{\prime}(x)}{S(x)}+f-\frac{P_{S}}{P}\right\}\left(\frac{x}{X}\right) \cdot P
$$

時間当り使用料 $l^{\prime}(x)$ は

$$
l^{\prime}(x)=\left\{\frac{S^{\prime}\left(x_{1}\right)}{S\left(x_{1}\right)}+f\right\} \frac{P}{X}
$$

スクラップ洒格 $P_{s}$ を計算に入れた場合 $\left(S(x)=P_{s}\right)$ は

$$
l^{\prime}(x)=\left\{\frac{S^{\prime}\left(x_{1}\right)}{S\left(x_{1}\right)}+f-\frac{P_{s}}{P}\right\} \frac{P}{X} .
$$

(3.61) （3.64) 式は(3.9), (3.10), (3.12) 特よび (3.13)式と比較して,小カッコ内の $1+f$ の項が $\frac{S^{\prime}\left(x_{1}\right)}{S(x)}+f$ と変わる。

\section{6. 使用料の算定公式（管理費を含めた場合）}

建設機械の使用料は特殊な場合を除いて，管理費を割掛けられたるのが実用とされる。従つて本項に挌いてふ すで示した各種の場合に和ける使用料管理費を割掛けて算定式を整理する。

管理費注つては, 購入価格に対する利子, 保険, 格納, 保管, その他機械運営上機械使用料江割掛けられる必 要がある経費を対象とする。

年間の管理費び年間の運転時間に割振られるため年間の 標準使用料括よび時間当り 使用料を算定するには年間 標準運転時間 $\overline{N x}$ 空定めて扔かねねばならない。

いま年間の管理費の購入費飞対する率，すなわち年基準管理率を $C$ とすると，年間標準使用料和よび時間当り 使用料次次のごとく表わされる。

\subsection{1. 年間標準使用料算定公式}

\section{（1）基本公式}

基本式は，機械を購入乙て物価の変動の考虑をする必要がなく，かつ機械ね新品であり，かつ標準価格で購入 された場合汇使用する。

$$
L \overline{(N x})=\left\{\left(1+f-\frac{P_{s}}{P}\right) \cdot \frac{\overline{N x}}{X}+C\right\} \cdot P
$$


ただし $\bar{N} x:$ 年間標準運転時間

$C$ ： 年基準管理率（保険，税金，利子，格納費等）

（2）修理費の物価変動を考光た場合の公式

機械購入時の修理費の物洒指数率を $\alpha_{1}$ とし, 運転時間が経過して $N x_{1}, N x_{2}, \cdots \cdots N x_{n-1}$ となつたとき, 修理費 の物価指数率が $\alpha_{2}, \alpha_{3}, \cdots \cdots, \alpha_{n}$ と変化したものとすると，算定公式は次のようになる。

（第 1 年次）物価指数率 $\alpha_{1}$ 飞括忷る式 $\left(\overline{N x_{1}}=N x_{1}\right)$

$$
L_{1}\left(\overline{N x}_{1}\right)=\left\{\left(1+\alpha_{1} \cdot f-\frac{P_{s}}{P}\right) \cdot \frac{\overline{N x_{1}}}{X_{1}}+C\right\} \cdot P
$$

$X_{1}$ : 物価指数率 $\alpha_{1}$ V括ける経済的耐用時間

（第 2 年次）物価指数率 $\alpha_{2}$ 飞括ける式 $\left(\overline{N x}_{2}=N x_{2}-N x_{1}\right)$

$$
L_{2}\left(\overline{N x}_{2}\right)=\left\{R_{2}\left(X_{2}\right)+P-P_{s}-L_{1}\left(\overline{N x_{1}}\right)\right\}\left(\frac{\overline{N x_{2}}}{X_{2}-N x_{1}}\right)+C \cdot P .
$$

ただし

$$
\begin{aligned}
& R_{2}\left(X_{2}\right)=\alpha_{2} \cdot f \cdot P\left\{\left(\frac{X_{2}}{X_{1}}\right)^{\left(1+\frac{1}{\alpha_{1} \cdot f}\right)}-\left(\frac{N x_{1}}{X_{1}}\right)^{\left(1+\frac{1}{\alpha_{1} \cdot f}\right)}\right\}+\alpha_{1} \cdot f \cdot P\left(\frac{N x_{1}}{X_{1}}\right)^{\left(1+\frac{1}{\alpha_{1} \cdot f}\right)} \\
& X_{2}=X_{1} \cdot\left(1+\frac{1}{\alpha_{1} \cdot f}\right) \sqrt{\frac{P-\alpha_{2} \cdot f \cdot P\left(\frac{N x_{1}}{X_{1}}\right)^{\left(1+\frac{1}{\alpha_{1} \cdot f}\right)}+R_{1}\left(N x_{1}\right)-L_{1}\left(N x_{1}\right)}{P\left\{\frac{\alpha_{2}}{\alpha_{1}}-\frac{N x_{1}}{X_{2}}\left(\alpha_{2} \cdot f+\frac{\alpha_{2}}{\alpha_{1}}\right)\right\}}} .
\end{aligned}
$$

（第 $n$ 年次）物価指数率 $\alpha_{n}$ そ括ける式 $\left(\overline{N x_{n}}=N x_{n}-N x_{n-1}\right)$

たぶし

$$
\left.L_{n} \overline{(N x}_{n}\right)=\left\{R_{n}\left(X_{n}\right)+P-P_{s}-L_{n-1}\left(\overline{N x}_{n-1}\right)\right\}\left(\frac{\overline{N x}_{n}}{X_{n}-N x_{n-1}}\right)+C \cdot P
$$

$$
\begin{aligned}
& R_{n}\left(X_{n}\right)=\alpha_{n} \cdot f \cdot P\left\{\left(\frac{X_{n}}{X_{1}}\right)^{\left(1+\frac{1}{\alpha_{1} \cdot f}\right)}-\left(\frac{N x_{n-1}}{X_{1}}\right)^{\left(1+\frac{1}{\alpha_{1} \cdot f}\right)}+R_{n-1}\left(N x_{n-1}\right) \cdots \cdots \cdots \cdots \ldots \ldots . \cdots\right. \\
& X_{n}=X_{1} \cdot\left(1+\frac{1}{\alpha_{1} \cdot f}\right) \sqrt{\frac{\left.P-\alpha_{n} \cdot f \cdot P\left(\frac{N x_{n-1}}{X_{1}}\right)^{\left(1+\frac{1}{\alpha_{1} \cdot f}\right.}\right)+R_{n-1}\left(N x_{n-1}\right)-L_{n-1}\left(N x_{n-1}\right)}{P\left\{\frac{\alpha_{n}}{\alpha_{1}}-\frac{N x_{n-1}}{X_{n}}\left(\alpha_{n} \cdot f+\frac{\alpha_{n}}{\alpha_{1}}\right)\right\}}}
\end{aligned}
$$

（3）購入価格を評価替した場合の公式

機械購入時の物価指数率を $\alpha_{1}$ とし, 運転時間が経過して $M x_{1}, M x_{2}, \cdots \cdots, M x_{n-1}$ となつたとき, 機械の物価指 数率が $\alpha_{2}, \alpha_{3}, \cdots \cdots, \alpha_{n}$ と変化し，それぞれ評価替をしたものとすると，算定公式は次のようとなる。

(購 入 時) 物洒指数率に $\alpha_{1}$ 扮汁る式 $\left(\overline{N x}_{1}=M x_{1}\right)$

$$
L_{1}\left(\overline{N x}_{1}\right)=\left[\left\{\alpha_{1} \cdot(1+f)-\frac{P_{s}}{P}\right\} \frac{\overline{N x}_{1}}{X_{1}}+C\right] \cdot P
$$

$X_{1}$ : 購入時物価指数率 $\alpha_{1}$ 飞扮汀る経済的耐用時間

(1 次評価後) 物価指数率 $\alpha_{2}$ 飞括㤝式 $\left(\overline{N x}_{2}=M x_{2}-M x_{1}\right)$

ただし

$$
L_{2}\left(\overline{N x_{2}}\right)=\left\{R_{2}\left(X_{2}\right)+\alpha_{2}\left(P-P_{s}\right)-L_{1}\left(M x_{1}\right)\right\}\left(\frac{\overline{N x_{2}}}{X_{2}-M x_{1}}\right)+C \cdot P
$$

$$
\begin{aligned}
& R_{2}\left(X_{2}\right)=\alpha_{2} \cdot f \cdot P\left\{\left(\frac{X_{2}}{X_{1}}\right)^{\alpha_{1} \cdot\left(1+\frac{1}{f}\right)}-\left(\frac{M x_{1}}{X_{2}}\right)^{\alpha_{1} \cdot\left(1+\frac{1}{f}\right)}\right\}+\alpha_{1} \cdot f \cdot P \cdot\left(\frac{M x_{1}}{X_{1}}\right)^{\alpha_{1} \cdot\left(1+\frac{1}{f}\right)} \\
& -\left(\alpha_{2}-\alpha\right) P \\
& X_{2}=X_{1} \cdot \sqrt[\alpha_{1}\left(1+\frac{1}{f}\right)]{\frac{\alpha_{2} P-\alpha_{2} \cdot f \cdot P\left(\frac{M x_{1}}{X_{1}}\right)^{\alpha_{1} \cdot\left(1+\frac{1}{f}\right)}+R_{1}\left(M x_{1}\right)-L_{1}\left(M x_{1}\right)}{f \cdot P\left\{\alpha_{1} \cdot \alpha_{2}\left(1+\frac{1}{f}\right)\left(1-\frac{M x_{1}}{X_{2}}\right)-\alpha_{2}\right\}}}
\end{aligned}
$$

(最後評価後) 物価指数率 $\alpha_{n}$ 飞括汀る式 $\left(\overline{N x_{n}}=M x_{n}-M x_{n-1}\right)$

$$
L_{n}\left(\bar{N}_{n}\right)=\left\{R_{n}\left(X_{n}\right)+\alpha_{n}\left(P-P_{s}\right)-L_{n-1}\left(M x_{n-1}\right)\right\}\left(\frac{\overline{N x_{n}}}{M_{n}-X x_{n-1}}\right)+C \cdot P
$$


ただし

$$
\begin{aligned}
& R_{n}\left(X_{n}\right)=\alpha_{n} \cdot f \cdot P\left\{\left(\frac{X_{n}}{X_{1}}\right)^{\alpha_{1} \cdot\left(1+\frac{1}{f}\right)}-\left(\frac{M x_{n-1}}{X_{1}}\right)^{\alpha_{n} \cdot\left(1+\frac{1}{f}\right)}\right\}+R_{n-1}\left(M x_{n-1}\right)-\left(\alpha_{n}-\alpha_{1}\right) P \\
& X_{n}=X_{1} \cdot \alpha_{1} \cdot\left(1+\frac{1}{f}\right) \sqrt{\frac{\alpha_{n} \cdot P-\alpha_{n} \cdot f \cdot P\left(\frac{M x_{n-1}}{X_{1}}\right)^{\alpha_{1} \cdot\left(1+\frac{1}{f}\right)}+R_{n-1}\left(M x_{n-1}\right)-L_{n-1}\left(M x_{n-1}\right)}{f \cdot P\left\{\alpha_{1} \cdot \alpha_{n}\left(1+\frac{1}{f}\right)\left(1-\frac{M x_{n-1}}{X_{n}}\right)-\alpha_{n}\right\}}}
\end{aligned}
$$

（4）中古機械の場合の公式

運転時間采計 $x_{1}$ の機械（ただし整備が完全にされているもの）購入価格 $S^{\prime}\left(x_{1}\right)$ で入手したとすると，

$$
\tilde{L}(\bar{N} x)=\left\{\left(\frac{S^{\prime}\left(x_{1}\right)}{S\left(x_{1}\right)}+f-\frac{P_{s}}{P}\right) \frac{\overline{N x}}{\bar{X}}+C\right\} P
$$

ただし

$$
S\left(x_{1}\right): x_{1} \text { 時間使用した機械の残存価格 }
$$

3.6.2. 時間当り使用料算定公式

(1) 基本公式

$$
l(x)=\left\{\left(1+f-\frac{P_{s}}{P}\right) \cdot \frac{1}{X}+\frac{C}{\overline{N x}}\right\} P
$$

（2）修理費の物価変動を考㝋た場合の公式

(第 1 年次) 物価指数率 $\alpha_{1}$ 飞招注式 $\left(\overrightarrow{N x}_{1}=N x_{1}\right)$

$$
l_{1}(x)=\left\{\left(1+\alpha_{1} \circ f-\frac{P_{s}}{P}\right) \frac{1}{X_{1}}+\frac{C}{\overline{N x_{1}}}\right\} \cdot P
$$

(第 2 年次) 物価指数率 $\alpha_{2}$ 江抒沪式 $\left(\overline{N x}_{2}=N x_{2}-N x_{1}\right)$

$$
l_{2}(x)=\left\{R\left(X_{2}\right)+P-P_{s}-L_{1}\left(N x_{1}\right)\right\}\left(\frac{1}{X_{2}-N x_{1}}\right)+\frac{C}{\overline{N x_{2}}} \cdot P
$$

(第 $n$ 年次) 物価指数率 $\alpha_{n}$ 飞和ける式 $\left(\bar{N} x_{n}=N x_{n}-N x_{n-1}\right)$

$$
l_{n}(x)=\left\{R_{n}\left(X_{n}\right)+P-P_{s}-L_{n-1}\left(N x_{n-1}\right)\right\}\left(\frac{1}{X_{n}-N x_{n-1}}\right)+\frac{C}{N x_{n}} \cdot P
$$

（3）購入価格を評価替した場合の公式

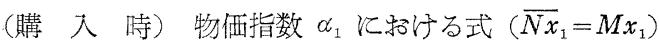

$$
l_{1}(x)=\left[\left\{\alpha_{1}(1+f)-\frac{P_{s}}{P}\right\} \frac{1}{X_{1}}+\frac{C}{\overline{N x_{1}}}\right] \cdot P
$$

(1 次評価後) 物価指数汇 $\alpha_{2}$ 括ける式 $\left(\overline{N x}_{2}=M x_{2}-M x_{1}\right)$

$$
l_{1}(x)=\left\{R_{2}\left(X_{2}\right)+\alpha_{2}\left(P-P_{s}\right)-L_{1}\left(M x_{1}\right)\right\} \frac{1}{X_{2}-M x_{1}}+\frac{C}{\overline{N x_{2}}} \cdot P
$$

(最終評価後) 物価指数 $\alpha_{n}$ に掠汀る式 $\left(\overline{N x_{n}}=M x_{n}-M x_{n-1}\right)$

$$
l_{n}(x)=\left\{R_{n}\left(X_{n}\right)+\alpha_{n}\left(P-P_{s}\right)-L_{n-1}\left(M x_{n-1}\right)\right\} \frac{1}{X_{n}-M x_{n-1}}+\frac{C}{\overline{N x_{n}}} \cdot P
$$

（4）中古機械の場合の公式

$$
l(x)=\left\{\left(\frac{S^{\prime}\left(x_{1}\right)}{S\left(x_{1}\right)}+f-\frac{P_{s}}{P}\right) \frac{1}{X}+\frac{C}{\overline{N x}}\right\} \cdot P
$$

ただし $S^{\prime}\left(x_{1}\right)$ : 中古機械購入価格

$S\left(x_{1}\right)$ : $x_{1}$ 時間使用した機械の残存佂格

第 4 章 ブルドーザの使用料等の算定に必要な使用美績 および使用料の計算害例

\section{1. 概 説}

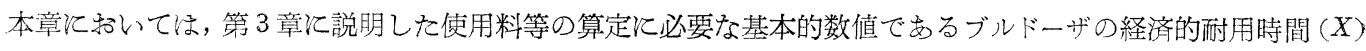


招よびそれまでに要する維持修理費の購入費に対する割合 $(f)$ を，多くの運転実績，修理実績並びに，他の文献 等も参考にして求める。その結果, 製作される国産ブルドーザは年を経るに従つて次第に改良され, 新しいるの ほぞ維持修理費が少なくなりつつあることが判明された。

な扮使用料の算定に影響岁る管理費等の実体を調査し，使用料の計算の実例を揭げた。

また修理費の見積りのための修理費率およびこれの定期整備を考慮した場合の補正法について実例をもつて説 明する。

\section{2. 運転時間の実績}

ブルドーザの年間運転時間は機械固有の性能により決まるのでねなく，機械の受入れ態勢，すなわち工事の種 類あるい注工事規模等により左右される。その顕著な例としては，建設省直轄工事に使用されるるので，民間の 機械化専門の建設業者のブルドーザと異なつて，その影響が特に大きい。

もし受入れ態勢の影響注より，運転時間が括さえられない大規模土工作業に従事した場合の年間運転時間を調べ るため昭和 25 年度より 28 年度の各年度に括いて年間運転時間の大きなるのをとると表一 4.1 のごとくである。

表一 4.1 亿よ机代年間運転時間はほぼ年々向上をたど り昭和 28 年度江称いては最高 10 位迄の平均は 2,000 時間近く汇めり, 10 20 位迄の平均は 1,668 時間であ るととで知る。しかし同じ昭和 28 年度, 建設省直轄 工事で稼㗢した国産ブルドーザ 191 台の年間運転時間 の平均は 1,068 時間であつた。

従つて国産ブルドーザに対しては，作業量が十分あ り建設省程度の運営管理を行つた場合は年間 2,000 時

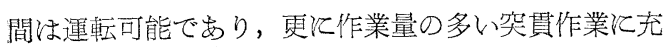
当した機械々 2,000 時間以上る運転可能とい方る。

建設省炕抬壮る昭和 25 年度以降の毎年の運転時間 の実績について調查した結果は 表一4.2 のようであ る。昭和 28 年度と招ける 1 年間の運転時間を見ると, 製作年度の新しいグループのものが, 漸增している傾 向は明らかである。また製作年度の古いグループにつ いて見ると，D-50 型炕関しては，昭和 24 年度、稆よ び bグループ，B B III型に関しては 24 年度のB B II 型 グループのるのの累計運転時間が，とれより新しいグ
表一4.1 大規模土工作業に従啛した場合の 年間運潮時間つ実績

\begin{tabular}{|c|c|c|c|c|c|}
\hline 位 & 25 & 年 度 & 26 年 度 & 27 年 度 & 28 年 度 \\
\hline $\begin{array}{l}1 \\
2 \\
3 \\
4 \\
5\end{array}$ & $\begin{array}{l}\times \\
\times \\
x \\
x\end{array}$ & $\begin{array}{l}2,184.0 \\
2,177.2 \\
1,767.3 \\
1,698.0 \\
1,692.2\end{array}$ & $\begin{array}{r}\times 1,945.8 \\
\times 1,880.0 \\
\times \quad 1,852.3 \\
\times \quad 1,810.7 \\
1,737.5\end{array}$ & $\begin{array}{r}\times 3,040.0 \\
\times 2,783.1 \\
\times 2,238.0 \\
\times 2,077.8 \\
2,028.3\end{array}$ & $\begin{array}{l}2,391.5 \\
2,116.1 \\
2.087 .6 \\
2,015.3 \\
1,911.6\end{array}$ \\
\hline $\begin{array}{r}6 \\
7 \\
8 \\
9 \\
10\end{array}$ & $\begin{array}{l}x \\
\times\end{array}$ & $\begin{array}{l}1,546.8 \\
1,544.0 \\
1,543.3 \\
1,462.9 \\
1,422.9\end{array}$ & $\begin{array}{r}1,710.8 \\
\times 1,645.0 \\
\times 1,634.0 \\
\times 1,597.3 \\
\times 1,565.6\end{array}$ & $\begin{array}{r}1,866.1 \\
\times 1,757.3 \\
\times 1,736.9 \\
1,731.5 \\
1,713.8\end{array}$ & $\begin{array}{l}1,901.6 \\
1,892.0 \\
1,863.6 \\
1,846.6 \\
1,823.2\end{array}$ \\
\hline 10 位迄平均 & & $1,704.9$ & $1,736.6$ & $2,097.3$ & 1.984 .9 \\
\hline $\begin{array}{l}11 \\
12 \\
13 \\
14 \\
15\end{array}$ & $x$ & $\begin{array}{l}1,203.0 \\
1,193.7 \\
1,181.0 \\
1,130.3 \\
1,110.5\end{array}$ & $\begin{array}{r}1,559.0 \\
\times 1,520.3 \\
1,514.6 \\
1,477.8 \\
1,464.9\end{array}$ & $\begin{array}{r}\times 1,686.0 \\
\times 1,679.2 \\
1,666.9 \\
\times \quad 1,665.3 \\
\times \quad 1,147.0\end{array}$ & $\begin{array}{l}1,760.0 \\
1,737.7 \\
1,718.6 \\
1,707.7 \\
1,699.5\end{array}$ \\
\hline $\begin{array}{l}16 \\
17 \\
18 \\
19 \\
20\end{array}$ & $x$ & $\begin{array}{r}1,063.6 \\
1,019.5 \\
993.0 \\
970.3 \\
9,655.8\end{array}$ & $\begin{array}{l}1,435.2 \\
1,414.6 \\
1,411.6 \\
1,392.8 \\
1,364.8\end{array}$ & $\begin{array}{r}1,645.0 \\
1,611.8 \\
1,587.5 \\
1,579.0 \\
\times \quad 1,577.0\end{array}$ & $\begin{array}{l}1,658.5 \\
1,608.6 \\
1,605.2 \\
1,591.4 \\
1.590 .6\end{array}$ \\
\hline $\begin{array}{l}10 \sim 20 \\
\text { 位迄均平 }\end{array}$ & & $1,106.4$ & $1,455,5$ & $1,634.5$ & $1,667.8$ \\
\hline
\end{tabular}

注 運転時間数の前にメ印の記してまるのは，ての機械が当斏年度購 大されたため 6 ケ月以上の運転月数はあるが 12 ケ月ないため月数 の割合で 12 ケ月にスライドした場合を示す。

\section{表一4.2 グループ别平均運転時間一覧表}

\begin{tabular}{|c|c|c|c|c|c|c|c|c|c|c|}
\hline \multirow{2}{*}{ 型 } & \multirow{2}{*}{ 度 } & \multirow{2}{*}{ グループ } & \multirow{2}{*}{ 資料台数 } & & 年 & 度 別 平 & 運 & 間 & & \multirow{2}{*}{ 運転特間累計 } \\
\hline & & & & 25 年 & 度 & 26 年 度 & 27 年 度 & 28 & 年 度 & \\
\hline D-50 & $\begin{array}{l}24 \\
24 \\
24 \\
25 \\
25 \\
26 \\
27 \\
\end{array}$ & $\begin{array}{l}\mathrm{a} \\
\mathrm{b} \\
\mathrm{c} \\
\mathrm{a} \\
\mathrm{b} \\
\mathrm{a} \\
\mathrm{a}\end{array}$ & $\begin{array}{r}17 \\
9 \\
8 \\
13 \\
7 \\
23 \\
3 \\
\end{array}$ & $\begin{array}{r}(456) \\
(325) \\
\times \quad 8) \\
\times \quad(3)\end{array}$ & $\begin{array}{l}684 \\
976 \\
985 \\
547 \\
221\end{array}$ & $\begin{array}{r}531 \\
714 \\
928 \\
865 \\
842 \\
\times(5) \quad 501\end{array}$ & $\begin{array}{r}445 \\
652 \\
1,123 \\
886 \\
929 \\
1,175 \\
\times(6) \quad 886 \\
\end{array}$ & & $\begin{array}{r}361 \\
883 \\
768 \\
917 \\
989 \\
1,228 \\
1,482 \\
\end{array}$ & $\begin{aligned} &(2,467) 2,021 \\
&(3,550) 3,225 \\
& 3,804 \\
& 3,215 \\
& 2,981 \\
& 2,904 \\
& 2,368 \\
&\end{aligned}$ \\
\hline B B III & $\begin{array}{l}24 \\
25 \\
25 \\
26 \\
27 \\
\end{array}$ & \begin{tabular}{|ll} 
B B II & $\mathrm{a}$ \\
& $\mathrm{a}$ \\
& $\mathrm{b}$ \\
& $\mathrm{a}$ \\
& $\mathrm{a}$ \\
\end{tabular} & $\begin{array}{r}5 \\
13 \\
7 \\
19 \\
3 \\
\end{array}$ & $\times \quad(6)$ & $\begin{array}{l}803 \\
467\end{array}$ & $\begin{array}{r}608 \\
955 \\
1,134 \\
\times(8) \quad 515\end{array}$ & $\begin{array}{r}795 \\
934 \\
1,008 \\
1,095 \\
\times(8) 1,036 \\
\end{array}$ & & $\begin{array}{r}728 \\
1,043 \\
864 \\
870 \\
1,245 \\
\end{array}$ & $\begin{array}{l}2,934 \\
3,399 \\
3,006 \\
2,480 \\
2,281 \\
\end{array}$ \\
\hline B B IV & $\begin{array}{l}27 \\
27 \\
\end{array}$ & $\begin{array}{l}\mathrm{a} \\
\mathrm{b}\end{array}$ & $\begin{array}{l}6 \\
3 \\
\end{array}$ & & & & 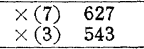 & & $\begin{array}{l}1,143 \\
1,291\end{array}$ & $\begin{array}{l}1,770 \\
1,834 \\
\end{array}$ \\
\hline $\mathrm{D}-80$ & $\begin{array}{l}25 \\
26 \\
26 \\
27 \\
\end{array}$ & $\begin{array}{l}\mathrm{a} \\
\mathrm{a} \\
\mathrm{b} \\
\mathrm{a}\end{array}$ & $\begin{array}{r}5 \\
6 \\
2 \\
10 \\
\end{array}$ & & & $\begin{array}{r}798 \\
\times \quad 3 \quad 236\end{array}$ & $\begin{array}{r}754 \\
1,080 \\
1,323 \\
\times(8) \quad 924 \\
\end{array}$ & & $\begin{array}{r}874 \\
1,051 \\
1,267 \\
1,149 \\
\end{array}$ & $\begin{array}{l}2,426 \\
2,367 \\
2,590 \\
2,073 \\
\end{array}$ \\
\hline B F & $\begin{array}{l}25 \\
26 \\
27\end{array}$ & $\begin{array}{l}\mathrm{a} \\
\mathrm{a} \\
\mathrm{a}\end{array}$ & $\begin{array}{r}5 \\
5 \\
10\end{array}$ & & & $\begin{array}{r}1,078 \\
\times \quad 5)^{6}\end{array}$ & $\begin{array}{r}1,054 \\
1,102 \\
\times(5) \quad 604 \\
\end{array}$ & & $\begin{array}{r}858 \\
1,024 \\
1,419 \\
\end{array}$ & $\begin{array}{l}2,980 \\
2,739 \\
2,023\end{array}$ \\
\hline
\end{tabular}

(註) 1. 年度別平均運転時間に×印のあるのは，年度の途中から運転を始め心場合の運転時間を示し，その右の括弧内の数字は当該年中の平均運 転月数を示宁。

2. D-50 の 24- $\mathrm{a}$ 及ざ 24-b グループの 25 年度の項の括弧内の数值は 24 年度中の運転時間の推定值を示す。運転時間累計括弧内の数値 は 24 年度よりの運転時間の累計を示す。 
ループより下廹つていることが明らかである。この古いグループ々性能上から 稼働率のきわめて悪いグループに 属し，更新の対象となるグループであることがわかる。

\section{3. 定期整備の実績}

定期整備飞要する費用结製作されてからの 運転時間の累計時間と，先の定期整借からの運転時間の長短㲹より 影響される。兒計の運転時間が増加すれば，連転時間当りの定期整供費の額増加する。定期整備と定期整備の 間隔を増せば，定期整備の際汇交換せる ばなら部品の数が多くなり費用も増大 する。機械が改良されて部品の品質が向 上されねね゙，定期整備費の額々減少す る。表-4.3 注建設省の昭和 28 年度実 績に扔けるグループ別の定期整備費と運 転時間との関係の一覧表である。

この表から判明することほ，運転 1 時 間当り平均定期整備費认，製作年月の新 しいグループの方が安くなつている。こ の原因は新しいグループほど機械が改良 され品質が向上したためと，運転時間の 累計が新しいグループほど少ないためで ある。

表一 4.4 ほ電源開発 K KVV括ける新品 輸入になるキャタピラD-8の修理費実績 であり，その中の定期整供飞ついての部 品費分解組立費,管理費の内訳を表一4.5 に示す。ただし表一4.4で見るようにり ンク (links) 怙よびシュー (shoes)を別

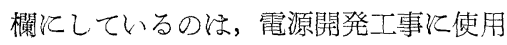
表-4.3 グループ别平均整備費一覧表

\begin{tabular}{|c|c|c|c|c|c|c|}
\hline 型 式 & 年度 & ゲループ & $\begin{array}{l}\text { 壊 料 } \\
\text { 数台 }\end{array}$ & $\begin{array}{l}\text { 定期整䚚までの } \\
\text { 平均運転時間 }\end{array}$ & 平均定期整備費 & $\begin{array}{l}\text { 運䎐 } 1 \text { 時間当り } \\
\text { 平均定期整備费 }\end{array}$ \\
\hline \multirow{7}{*}{$D-50$} & 24 & a & 7 & 879 & $840,539^{\text {用 }}$ & $956^{\text {円 }}$ \\
\hline & 24 & $\mathrm{~b}$ & 2 & 787 & 836,041 & 1,063 \\
\hline & 24 & c & 6 & 1,800 & $1,075,634$ & 597 \\
\hline & 25 & a & 9 & 1,179 & 879,445 & 746 \\
\hline & 25 & $\mathrm{~b}$ & 2 & 1,630 & $1,238,110$ & 760 \\
\hline & 26 & a & 14 & 1,668 & 852,000 & 511 \\
\hline & 27 & $\mathrm{a}$ & 3 & 1,722 & 899,176 & 522 \\
\hline \multirow{5}{*}{ B B III } & 24 & $\underset{\mathrm{a}}{\mathrm{B} \text { B II }}$ & 2 & 1,070 & $1,206,300$ & 1,127 \\
\hline & 25 & $\mathrm{a}$ & 11 & 1,493 & $1,700,624$ & 1,139 \\
\hline & 25 & b & 7 & 1,771 & $1,509,477$ & 1,134 \\
\hline & 26 & a & 13 & 1,272 & $1,036,107$ & 815 \\
\hline & 27 & a & 2 & 898 & 628,679 & 700 \\
\hline \multirow{2}{*}{ B B IV } & 27 & $\mathbf{a}$ & 4 & 1,122 & $1,015,292$ & 927 \\
\hline & 27 & $\mathrm{~b}$ & 0 & - & - & - \\
\hline \multirow{4}{*}{$D-80$} & 25 & a & 3 & 1,430 & $1.597,000$ & 1,113 \\
\hline & 26 & a & 5 & 1,657 & $1,372,402$ & 832 \\
\hline & 26 & b & 2 & 2,040 & $2,207,514$ & 1,082 \\
\hline & 27 & a & 10 & 1,649 & $1,011,182$ & 613 \\
\hline \multirow{3}{*}{ B F } & 25 & a & 3 & 926 & $1,339,300$ & 1,446 \\
\hline & 26 & a & 7 & 1,144 & $1,083,000$ & 947 \\
\hline & 27 & $\mathrm{a}$ & 3 & 1,682 & 846,596 & 503 \\
\hline
\end{tabular}

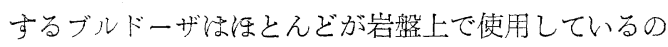
でこれらの足腼り部品の損粍が特にはなほだしく， 標準土工の場合の 3 倍程度の実績を示しており，これ の整備時期がエンジン等の全分解整備と同じ時期と実 施し得ず，従つてシュー，リンク拉よび現場小修理に ついてはとの費用標準土工の場合渻算して，小修理 費を加えたるのを計上した。それは後述する $f$ の值を 求める必要があるからである。

表一 4.5 亿より部品費が約 $65 \%$ ，分解組立費が約

表一4.4 キャタピラ D-8 修理費実績

\begin{tabular}{|c|c|c|c|c|c|}
\hline \multirow[b]{2}{*}{ 車 体 番 号 } & 定期整備 & 修 & 理 & 費 & \multirow{2}{*}{$\begin{array}{l}\text { 時間当り } \\
\text { 修 理 費 }\end{array}$} \\
\hline & $\begin{array}{l}\text { までの } \\
\text { 運転時間 }\end{array}$ & 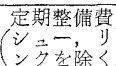 & 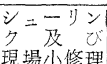 & 計 & \\
\hline $2 \mathrm{U}-23412$ & $2,500^{\mathrm{h}}$ & $1,760,947$ & $\begin{array}{r}\text { 网 } \\
705,541\end{array}$ & \begin{tabular}{r|}
$\mathrm{P}$ \\
$2,466,488$
\end{tabular} & ${ }_{985}^{\text {円 }}$ \\
\hline $2 \mathrm{U}-22222$ & 3,600 & $2,378,851$ & 870,796 & $3,249,547$ & 905 \\
\hline $2 \mathrm{U}-21465 \mathrm{sp}$ & 4,460 & $2,697,474$ & $1,336,134$ & $4,033,608$ & 870 \\
\hline $2 \mathrm{U}-18390$ & 5,000 & $3,768,018$ & $1,433,456$ & $5,201,474$ & 1,040 \\
\hline $2 U-13026$ & 6,550 & $3,305,486$ & $2,314,634$ & $5,620,120$ & 860 \\
\hline $2 \mathrm{U}-16404 \mathrm{sp}$ & 6,870 & $3,655,279$ & $2,378,232$ & $6,033,510$ & 880 \\
\hline
\end{tabular}
$22 \%$ で，部品費と分解組立費の割合が 3 と 1 の割合い《なつている。2 U-23412 号の分解組立費の多いのは特に 破損修理のため溶接に多くの工数をとられたためであつた。

表一 4.5 キャタピラ D-8 定期整備実績内訳

\begin{tabular}{|c|c|c|c|c|c|c|c|c|c|c|}
\hline & & 部 品 費 & 分解組立費 & 管 理 費 & & 構 & 成 & 百 & & 率 \\
\hline 車体 番 号 & 運 軽 時 間 & （交換及ざ修理） & （消粒品老含七） & （輸送費を含的） & 部 & 品 費 & 分 解 & 組 立費 & 管 & 理 費 \\
\hline $2 \mathrm{U}-23412$ & $2,500^{\mathrm{h}}$ & $749,207^{\text {円 }}$ & $806,199^{\text {円 }}$ & $205,541^{\mathrm{F}}$ & & $43^{\%}$ & & $46^{\%}$ & & $11^{\%}$ \\
\hline $2 \mathrm{U}-22222$ & 3,600 & $1,538,804$ & $569 ; 151$ & 270,796 & & 65 & & 24 & & 11 \\
\hline $2 \mathrm{U}-21465 \mathrm{sp}$ & 3,460 & $1,616,832$ & 744,508 & 336,134 & & 60 & & 28 & & 12 \\
\hline $2 \mathbf{U}-18390$ & 5,000 & $2,590,914$ & 743,648 & 433,456 & & 69 & & 20 & & 11 \\
\hline $2 U-13026$ & 6,550 & $2,200,559$ & 672,610 & 432,317 & & 66 & & 21 & & 13 \\
\hline $2 \mathrm{U}-16404 \mathrm{sp}$ & 6,870 & $2,552,834$ & 638,328 & 464,116 & & 70 & & 18 & & 12 \\
\hline
\end{tabular}




\section{4. $\boldsymbol{X}$ および $\boldsymbol{f}$ の值}

\subsubsection{A.G.C.A. Ф資料}

経済的耐用時間 $X$ 扝よび $X$ までの修理費の累計の購入費に対する割合 $f$ 亿関する資料として最も信頼すべきも のとして, A.G.C.A. (Associated General Contructors of America I.N.C.) の発表している Construction Equipment Ownership Expense があ り，米国で一般使用されている建設機 械の使用料算定に関する具体的な標準值 を示したものである。その最近の 1949 年版にはブルドーザについて表一4.6の ようと示されている。

表一4.6から知れることは，A.G.C.A. 表-4.6 A.G.C.A. の Const. Equipment Expense より

\begin{tabular}{|c|c|c|c|c|c|c|c|}
\hline 種 & $\begin{array}{l}\text { 型 } \text { 式 } \\
(\mathrm{P})\end{array}$ & $\begin{array}{c}\text { 年償却率 } \\
(\%) \\
\mathrm{D}\end{array}$ & $\begin{array}{l}\text { 整備率 } \\
(\%) \\
\text { OR }\end{array}$ & 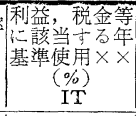 & $\begin{array}{c}\text { 所有者 } \\
\text { 経費 } \\
(\%) \\
\text { Tot } \\
\text { Tot }\end{array}$ & $\begin{array}{c}\text { 年 平均 } \\
\text { 使用月数 } \\
(\%) \\
\text { U }\end{array}$ & $\begin{array}{c}\text { 月当 経費 } \\
(\%) \\
E / m_{0}\end{array}$ \\
\hline & $\sim 42$ & 33 & 20 & 11 & 64 & 8 & 8.0 \\
\hline ブルドーザ & $42 \sim 66$ & 25 & 20 & 11 & 56 & 8 & 7.0 \\
\hline \multirow{2}{*}{$\left(テ_{1}-\right.$ ぜル) } & $66 \sim 89$ & 25 & 15 & 11 & 51 & 8 & 6.4 \\
\hline & $89 \sim 163$ & 20 & 15 & 11 & 45 & 8 & 5.8 \\
\hline
\end{tabular}

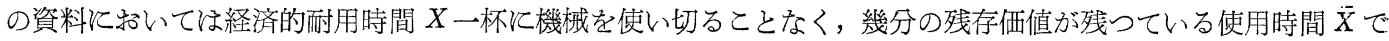
機械を償却することを条件としている。この時間 $\bar{X}$ 効用持続時間といい次式の関係皇るる。

$$
\bar{X}=\frac{30 \times U \times t}{D} \times 100
$$

ただし $t$ は 1 日平均運転時間で中岡二郎氏の考察によれば 5 時間（月稼働日数を 25 日とすれば 6 時間 20 日と すれば 7.5 時間となる)とみなされている。

また効用持続時間 $\bar{X}$ までの定期整備費䍗計の購入費に対する比率 $\beta \bar{X}$ は

$$
\beta \overline{\mathrm{X}}=\frac{O R}{D}
$$

以上の結果より，効用持続時間 $\bar{X}$ (4.1) 式とより求め同時間までの 定期整備費累計の購入費に対する比率 $\beta \bar{X}$ を (4.2) 式により求めると その結果は表一4.7のようとなる。

次㳊济的楖用時間 $X$ は Ackerman の Construction Planning and plant (1940) そよると，10,000 時間とされて和り，また中岡二郎氏の A.G.C.A. 資料と Ackerman 資料との関連性から求めた数值によれね゙ (建設の機械化昭和 27 年 4 月号 41 ページ参照) 表一 4.8 のようとなつ ているのでブルドーザの経済的耐用時間を 10,000 時間と想定するのが よい。

次に $f$ の值を知るそは， $X=10.000$ 時間として表一4.7の A.G.C.A. より求めた各型式の $\bar{X}, \beta \bar{X}$ 亿相当する $f$ 执よび $\delta \bar{X}(\bar{X}$ 時間炕打る残

表-4.7 A.G.C.A.上り求めた

\begin{tabular}{|c|c|c|c|}
\hline 種 & 型 $(\mathrm{H})^{\text {式 }}$ & $\underset{(\mathrm{hr})}{\bar{X}}$ & $\beta \bar{X}$ \\
\hline & $\sim 42$ & 3,600 & 6.60 \\
\hline ブルドーザ & $42 \sim 66$ & 5,000 & 0.80 \\
\hline \multirow[t]{2}{*}{$\left(テ_{1}\right.$-ゼル) } & $66 \sim 89$ & 5,000 & 0,60 \\
\hline & $89 \sim$ & 6,000 & 0.75 \\
\hline
\end{tabular}
$\boldsymbol{X}, \boldsymbol{\beta}_{X}$ Ф值

表一4.8 中岡氏の求めた $\bar{X} の$ 值

\begin{tabular}{l|c|c}
\hline 機 & 種 & 型 \\
\hline P & 式 & 経済的而用時間 \\
\hline ブルドーザ & $20 ー 30$ & 10,000 \\
(ディーゼ & $52 \sim 62$ & 11,800 \\
\hline
\end{tabular}
存価格率）の值を計算すると表一 4.9 の ように $f$ が求められる。

4.4.2. 国淕ブルドーザについての值 わが国で使用している，主として国産 ブルドーザそついての $X$ および $f$ の值 に求めるために表一 4.2 扮よび表一 4.3

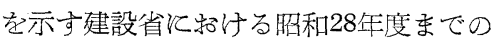

\begin{tabular}{|c|c|c|c|c|c|c|}
\hline \multirow{2}{*}{ 型 } & \multirow{2}{*}{\multicolumn{2}{|c|}{ 式 }} & \multicolumn{2}{|c|}{ A.G.C.A.より求めた值 } & \multicolumn{2}{|c|}{$X=10,000 \mathrm{hr}$ とした場合 } \\
\hline & & & $\bar{X}$ & $\beta \bar{X}$ & $f($ そのときの $\beta \bar{X}$ の值 & $\delta \bar{X}$ \\
\hline & $\sim$ & 42 & 3,600 & 0.60 & $2.5(\beta \bar{X}=0.590)$ & 0,338 \\
\hline 42 & $\sim$ & 66 & 5,000 & 0.80 & $2.2(\beta \bar{X}=0.802)$ & 0.202 \\
\hline 66 & $\sim$ & 89 & 5,000 & 0.60 & $1.8\left(\beta_{\bar{X}}=0.612\right)$ & 0.212 \\
\hline 89 & $\sim$ & & 6,000 & 0.75 & $1.7(\beta \bar{X}=0.755)$ & 0.135 \\
\hline
\end{tabular}

表一4.9 $X=10,000$ 時間とした場合の $f$ および $\delta_{X}$ の值 グループ別平均運転時間一覧表䄈よび昭和 28 年度のグループ別平均整備費一覧表により実験的汇算定することが できる。しかし $f$ の值を算定するにね $X$ の值を仮定しなければならない。

$X$ の值ほ前項に示したと同㥞 $10,0 C 0$ 時間と仮定すればよい。 $X$ の值が増減すると $f$ の值は增減するが，時間

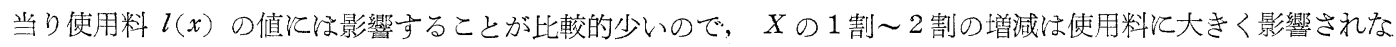
W。

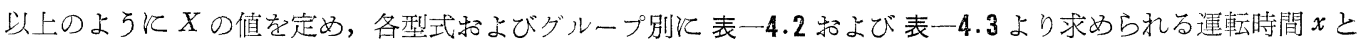

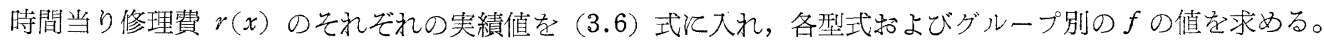

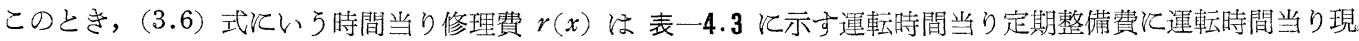
場小修理費を加光たもので，本計算飞括いては機械の現場管理の良い場合として時間当り現場小修理費を定期整 備費の 1 割として計算する。 


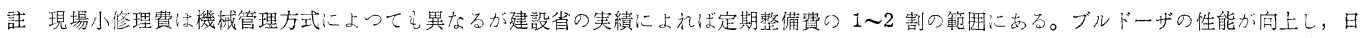
常整備を十分行えば現場小修理費が漱減する傾向にある。

このとき購入価格々定期整備実績を求めたと同年度の炤和 28 年度の標準購入価格である 表一 4.10 の価格を使 用する。昭和 29 年度 30 年度もほとえど変化ないので 28 年度価格を便用してるよい。

この (3.6) 式にょる $f$ の計算に当つては図式解法に こり，時間当り修理費，運転時間と $f$ の関係を図表に 書いてこれに実績值を記入すると図一4.1〜図-4.3 に示す結果が得られる。

以上の結果に基いて，使用粼計算に使用する $f$ の值 社表一4.11を用いるのが適当である。

\section{図-4.1}

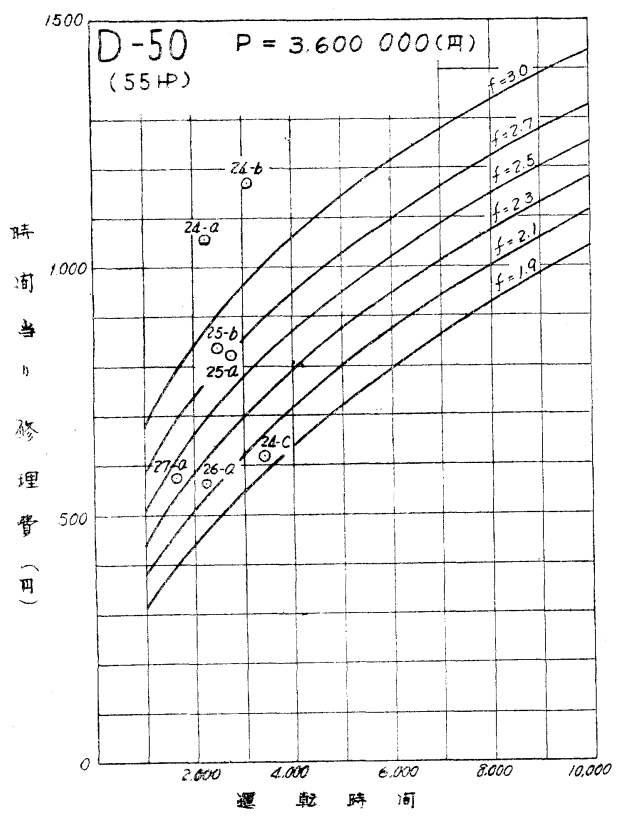

図-4.2

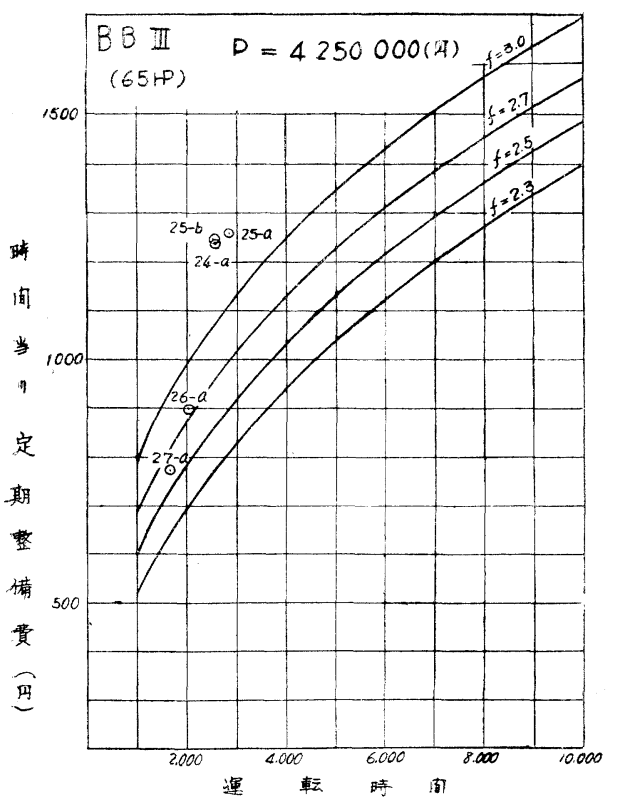

表一4.10 国産ブルドーザ昭和 28 年度標準価格

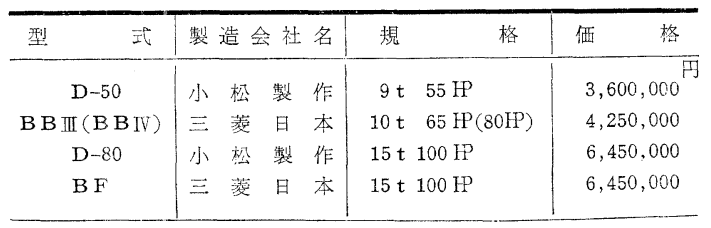

図一 4.3

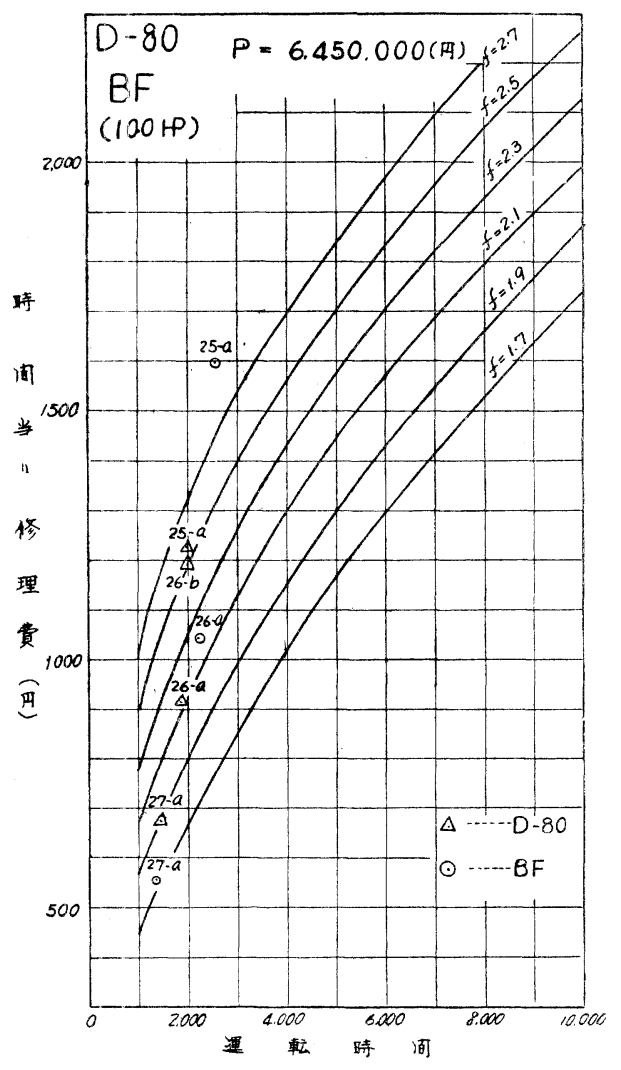

表一4.11 使用料に用いる $f$ 值

\begin{tabular}{|c|c|c|c|c|c|c|c|}
\hline 型 & \multicolumn{2}{|c|}{ 型 } & 式 & 25年度製 & \multirow{2}{*}{$\frac{26 \text { 年度製 }}{2.4}$} & \multirow{2}{*}{$\frac{27 \text { 年度製 }}{2.4}$} & \multirow{2}{*}{$\begin{array}{l}\text { 28年度以降 } \\
\text { 推 }\end{array}$} \\
\hline \multirow{3}{*}{ 国 } & 小 & 松 & $\mathrm{D}-50$ & 2.7 & & & \\
\hline & & B III. & $\mathrm{BBIV}$ & - & 2.7 & 2.6 & 2.2 \\
\hline & 小 & 松 & D-80 & 2.7 & 2.2 & 1.9 & 1.7 \\
\hline \multirow{4}{*}{ 産 } & $\equiv$ & 菱 & B F & 2.7 & 2.2 & 1.9 & 1.7 \\
\hline & 小 & 松 & D-120 & - & - & - & 1.7 \\
\hline & 日 & 特 & NTK-4 & - & - & - & 2.2 \\
\hline & 日 & 特 & NTK-7 & - & - & - & 1.8 \\
\hline
\end{tabular}

ただし $f$ の值はブルドーザの作業条件，特に取り扱う土質 执よび路般の状態执よび機械の管理の良否により異なつた 值を用いなければならない。この補正についての詳細な数 值は得られていないが，走行部の損䊒等より判断すると次 のごとく $f$ の值を補正するのがよいと考光る。 
軽い土工作業 $0.5 \sim 1.0$ 割減

水中, 砂利地, 軟弱地での作業...... $0.5 \sim 1.0$ 割增

岩般での作業..... $1.5 \sim 2.0$ 割增

4.4.3. キャタピラ D-8についての值

輸入になるキャタピラ D-8 をわが国で使用した場合の $f$ の值を, 前項と同様 $X=10.000$ 時間として，(3.5； 式を用い，表一4.4の実績から求めると図一4.4のよう店 る。

ただし，修理費の累計に゙後述4.7.1.の（2）で説明すると捛 り階段状に増加していくものであり，これに基く補正を考慮し て $f$ の值購入価格走国内免税価格 10,700,000 円とした場合 は 1.3 が適当とみなされる。

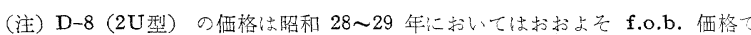
9,250,000 円 c.i.f.（横浜）で 10,000,000 円，国内免税価格で 10,700,000 円 国内税込灭価格て $12,200,000$ 円で岕る。

従つてキャタピラーD-8 抢よびこれ《類似するブルドーザの $f$ の值任表一4.12 江示すもの兴標準とする。

表一 4.12 で示すと扮り 国内価格でも輸入税の有無により異 なる。

岩般での作業ふ足廻との損粍がねなはだしく，標準土工の場 合飞比較して，修理金額で約 $40 \%, f$ の值で約 2 割増加す るととが実績より判明した。

い委一 4.5 亿示したようと部品費と分解組立費の 割合が 3 と 1 の割合であるとすると $f=1.3$ (国内免税 価格の場合) の内訳㳄次のと括り。

$1.3=0.87$ (部品費) +0.28 (分解組立費 $)+0.15$ (管理 費）これがアメリカ本国で実施されたるのとして換 算すれば部品費は約 3 割安くなるが，労力費は間接費 を含めて 3 倍とすれば

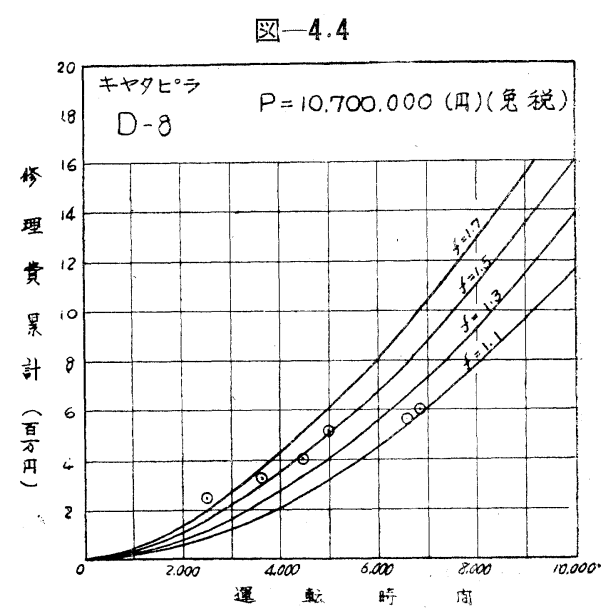

表一4.12 キャタピラーD-8のfの值

\begin{tabular}{|c|c|c|c|c|}
\hline \multirow{2}{*}{ 購入佂格の区分 } & \multirow{2}{*}{ 価＼cjkstart格 } & \multirow{2}{*}{$\omega$} & $f \quad$ の & 値 \\
\hline & & & 標準土工 & $\begin{array}{l}\text { 岩盤ての } \\
\text { 作 業 }\end{array}$ \\
\hline $\begin{array}{l}f .0 . b . \text { 価 格 } \\
\text { c.i.f (棤浜) 伍格 }\end{array}$ & $1+0$ & $\begin{array}{c}1 \\
.08=1.08\end{array}$ & $\begin{array}{l}(1.5) \\
(1.4)\end{array}$ & $\begin{array}{l}(1.7) \\
(1.6)\end{array}$ \\
\hline \begin{tabular}{l|lr} 
国内 & 免 税 \\
価格 & 翰入税込又
\end{tabular} & $\begin{array}{r}1.08 \times(1 \\
1.08 \times(1+0\end{array}$ & $\begin{array}{l}+0.07)=1.16 \\
.07+0.15)=1.32\end{array}$ & $\begin{array}{l}1.3 \\
1.2\end{array}$ & $\begin{array}{l}1.5 \\
1.4\end{array}$ \\
\hline
\end{tabular}

（注）括弧は実際には計算に使用されない場合の $f$ の值である。

$$
0.87(1-0.3)+0.28 \times 3+0.15=1.599
$$

すなわち表一4.9 そ示した A.G.C.A. の資料より求めた $f$ の值 $(f=1.7)$ 飞近い值をとることができる。

\section{5. 管理費その他}

\subsection{1. 管 理 費}

使用料割掛けられる管理費は，運営形態の差異により，その必要な割合が変化する。年基準管理率 $C$ の值と しては，購入費に対する金利 $10 \%$ ，管理のための運営費との他として購入費の $5 \%$ ，計 $15 \%$ が民間会社でほ最: 小限必要であると考党られる。

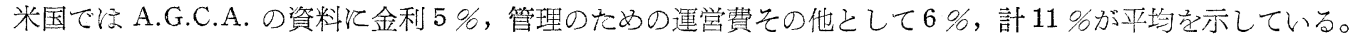

1 例として，保有する機械台数も多く，地域的モータープールにより修理施設も完備している建設省河ける

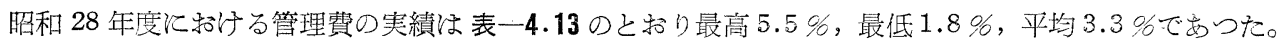

表一 4.13 昭和 28 年度建設省各地建における年基準管理率（単位千円）

\begin{tabular}{|c|c|c|c|c|c|c|c|}
\hline & 東 北 地 建 & 関 東 地 建 & 中 部 地 建 & 近幾 地 建 & 中 四地建 & 九州地 建 & (平 均) \\
\hline 保有機械眦入価格 & $1,150,000$ & $1,404,000$ & $1,566,000$ & 817,000 & 785,000 & 950,000 & $6,672,000$ \\
\hline 管理費 (1ケ年分) & 28,158 & 51,115 & 27,599 & 38,334 & 43,046 & 30,909 & 219,155 \\
\hline 年基準管理率(\%) & 2.5 & 3.7 & 1.8 & 4.7 & 5.5 & 3.3 & 3.3 \\
\hline
\end{tabular}

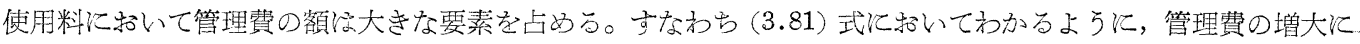
かかわらず使用料を一定に保つためには，管理費の増大した割合いだけ年間の運転時間を增大させねね゙ならな: 
管理費が前文で説明したるうに購入費の $15 \%$ を要する場合は時間当り使用料のうち管理費の占める割合注約 1/3であり，使用料を低額沉するめには管理費を切り詰めるか，年間の運転時間の増大を計らねばならない。す なわち管理費が 2 倍に增大して 同じ使用料で同じ採用を得るためには，年間運転時間を 2 倍になるように機械を 稼㗢させなければならぬ。

\subsection{2. スクラップ価格 $\boldsymbol{P}_{s}$}

スクラップは材質の種類，招よびそのときの市価により異なるが，酎当りの価格を平均 10,000 円とすると各種 ブルドーザについては 表一4.14のようとなる。

従つて計算に视 $P_{s} / P$ の值を大約平均して 0.02 を 用亏ると, 所有者として安全側である。

\subsection{3. 物価の変動経過}

使用料の計算飞当り，修理費の物価変動を考慮しな ければならぬ場合と，購入価格を評価替兄して使用料 を計算しなければならぬ場合が起る。

修理費の物価変動沉つてて, 部品の価格変化と修 理工の労賃のベースの変化の総合した物価指数を用い なければならぬが，これを求めることは困難であると きは，便宜上標準購入価格の変動汇よる指数を用いる ことも致しかたない。

国産ブルドーザ 5 型式について，昭和 24 年度より 炤和 28 年度までの標準購入価格を参考まで示せば 表一 4.15 のと括り。

表-4.14 $P_{s} / P$ ○ 值

\begin{tabular}{|c|c|c|c|c|c|}
\hline \multicolumn{3}{|c|}{ 型 } & \multirow{2}{*}{$\frac{(\mathrm{t})^{\text {重 }}}{19}$} & \multirow{2}{*}{ 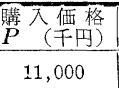 } & \multirow{2}{*}{$\frac{P_{S} / P}{0.017}$} \\
\hline$\neq$ & $\uparrow$ 夕 ピ ラー & $\mathrm{D}-8$ & & & \\
\hline & $"$ & $\mathrm{D}-7$ & 15 & 9,500 & 0.016 \\
\hline 小 & 松 & D-50 & 9 & 3,600 & 0.025 \\
\hline$\Xi$ & 菱 B B III, & B B IV & 10 & 4,250 & 0.024 \\
\hline 小 & 松 D-80, 三 & 䔖 B F & 16 & 6,450 & 0.025 \\
\hline 日 & 特 & NTK-4 & 6.2 & 4,500 & 0.014 \\
\hline & $"$ & NTK-7 & 13.5 & 5,250 & 0.026 \\
\hline 小 & 松 & $\mathrm{D}-120$ & 20.5 & 9,000 & 0.023 \\
\hline
\end{tabular}

表一4.15 標準購入価格（単位千円）

\begin{tabular}{cc|c|c|r|r|r}
\hline 年 & 度 & 小松D-50 & 三菱B B III & 三菱B B IV & 小松D-80 & 三菱B F \\
\hline 昭 & 24 & 2,470 & 2,700 & - & - & - \\
" & 25 & 2,600 & 2,900 & - & 5,000 & 5,000 \\
" & 26 & 3,400 & 4,150 & - & 6,200 & 6,400 \\
" & 27 & 3,400 & 4,200 & 4,200 & 6,400 & 6,400 \\
" & 28 & 3,600 & - & 4,250 & 6,450 & 6,450 \\
\hline
\end{tabular}

\section{6. 使用料の計算}

第 3 章に招いて説明した使用料の算定理論とより，基本的な計算の範例並びそその結果から得られた 使用料の 特異性について説明を補足する。実際の使用料の決定に当つてはそれぞれの条件適合した係数を選んで行うべ きであるが，その標準的な条件汸括る計算例を示す。

\subsection{1. 基本式による場合}

年間標準使用料 $L(\overline{N x})$

$$
L \overline{(N x)}=\left\{\left(1+f-\frac{P_{s}}{P}\right) \cdot \frac{\overline{N x}}{X}+C\right\} \cdot P
$$

時間当り使用料 $l(x)$

$$
l(x)=\left\{\left(1+f-\frac{P_{s}}{P}\right) \cdot \frac{1}{X}+\frac{C}{\overline{N x}}\right\} \cdot P
$$

上記 2 式により $P_{s} / P=0.02, C=0.15$ の場合の昭和 28 年度の購入ブルドーザとついて計算した結果は，表一 4.16 のと捛りであり，スクラップ価格 $P_{s}$ を零とした場合は 表一 4.17 のと㣛りである。購入価格 $P$ は表一 4.10 抢よび 4.4.3. 亿示す佂格を用う。

\begin{tabular}{|c|c|c|c|c|c|c|c|c|}
\hline \multirow{2}{*}{ 型 } & \multirow{2}{*}{ 式 } & \multirow{2}{*}{$f$} & \multicolumn{3}{|c|}{ 年間 標準 使用 料 (千 円) } & \multicolumn{3}{|c|}{ 時 間 当 り 使 用 料 (円) } \\
\hline & & & $N x=1.000 h$ & $=1.500 \mathrm{~h}$ & $=2,000 h$ & $=1,000 \mathrm{~h}$ & $=1,500 h$ & $=2,000 \mathrm{~h}$ \\
\hline 小 & $\mathrm{D}-50$ & 2.2 & 1,685 & 2,252 & 2,829 & 1,685 & 1,505 & 1,415 \\
\hline 三菱 B B III & III, B BIV & 2.2 & 1,989 & 2,665 & 3,341 & 1,989 & 1,777 & 1,670 \\
\hline 小松 D-80 & 三菱 BF & 1.7 & 2,696 & 3,561 & 4,425 & 2,696 & 2,374 & 2,212 \\
\hline 特 & NTK-4 & 2.2 & 2,106 & 2,822 & 3,537 & 2,106 & 1,881 & 1,769 \\
\hline " & NTK-7 & 1.8 & 2,247 & 2,977 & 3,707 & 2,247 & 1,985 & 1,853 \\
\hline 松 & $\mathrm{D}-120$ & 1.7 & 3,762 & 4,968 & 6,174 & 3,762 & 3,312 & 3,087 \\
\hline キャタピラー & $D-8$ & 1.3 & 4,045 & 5,157 & 6,270 & 4,045 & 3,438 & 3,135 \\
\hline " & $\mathrm{D}-7$ & 1.3 & 3,402 & 4,248 & 5,274 & 3,402 & 2,832 & 2,637 \\
\hline
\end{tabular}

表一4.16 ブルドーザ使用料の算定值 $\left(\boldsymbol{S}(\boldsymbol{x})=\boldsymbol{P}_{s}, \boldsymbol{C}=\mathbf{0 . 1 5}\right.$ の場合 $)$

（注）キャタピラーD-8 およびD-7 涊国内免税洒格 10,700,000円およで 9,000,000円として計算した。 
表一4.17 ブルドーザ使用料つ算定值 $(S(x)=0 \quad G=0.15$ の場合 $)$

\begin{tabular}{|c|c|c|c|c|c|c|c|c|}
\hline \multirow{2}{*}{ 型 } & \multirow{2}{*}{ 式 } & \multirow{2}{*}{$f$} & \multicolumn{3}{|c|}{ 年間 標準使 用 料 (千 円) } & \multicolumn{3}{|c|}{ 時 間 当 り使用 料 (円) } \\
\hline & & & $\bar{N} \bar{x}=1,000 h$ & $=1,500 h$ & $=2,000 \mathrm{~h}$ & $=1,000 \mathrm{~h}$ & $=1,500 \mathrm{~h}$ & $=2,000 h$ \\
\hline 小 & $\mathrm{D}-50$ & 2.2 & 1,692 & 2,268 & 2,844 & 1,692 & 1,512 & 1,422 \\
\hline 三菱 $\mathrm{B} \mathrm{B}$ & , BBIV & 2.2 & 1,998 & 2,678 & 3,358 & 1,998 & 1,785 & 1,679 \\
\hline 小松 D-80, & 已萲 B F & 1.7 & 2,709 & 3,580 & 4,451 & 2,709 & 2,387 & 2,225 \\
\hline 日 & NTK -4 & 2.2 & 2,115 & 2,835 & 3,555 & 2,115 & 1,890 & 1,778 \\
\hline$"$ & NTK-7 & 1.8 & 2,258 & 2,993 & 3,728 & 2,258 & 1,995 & 1,864 \\
\hline 小 & $\mathrm{D}-120$ & 1.7 & 3,780 & 4,995 & 6,210 & 3,780 & 3,330 & 3,105 \\
\hline キャ夕ピラー & D-8 & 1.3 & 4,066 & 5,189 & 6,313 & 4,066 & 3,460 & 3,157 \\
\hline ' $\quad$ " & $\mathrm{D}-7$ & 1.3 & 3,420 & 4,280 & 5,317 & 3,420 & 2,855 & 2,658 \\
\hline
\end{tabular}

4.6.2. 修理費の物価変動を考えた場合

計算例として

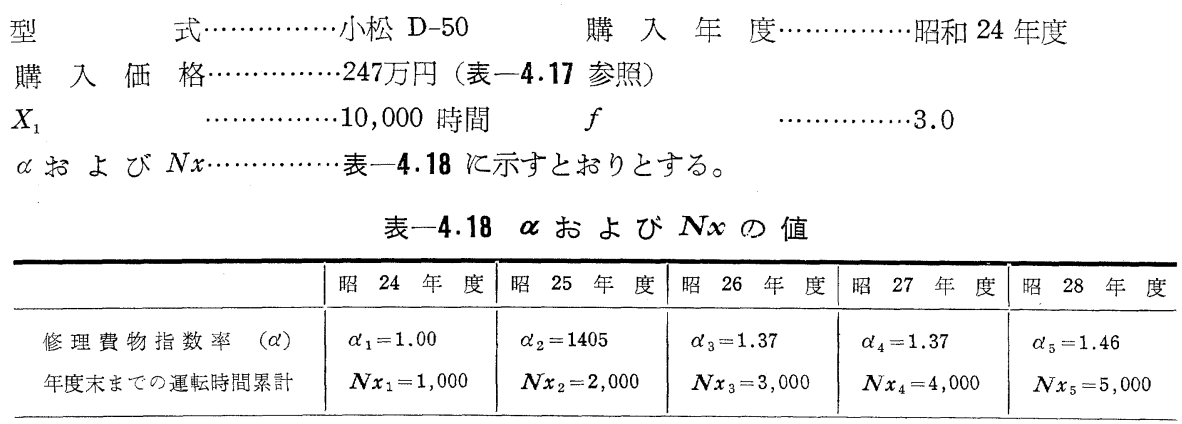

以上の場合の各年度に和ける使用料を計算する。ただし管理費拉よびスクラップ価格は計算に入れない場合に ついて行う。

まず（3.14）式括よび (3.22)〜 (3.24) 式により $R_{1}\left(N x_{1}\right), R_{2}\left(N x_{2}\right), \cdots \cdots R_{5}\left(N x_{5}\right)$ を求める。

$$
\begin{aligned}
R_{1}\left(N x_{1}\right) & =1.00 \times 3.0 \times 2,470,000 \times\left(\frac{1,000}{10,000}\right)^{\left(1+\frac{1}{3.0}\right)} \\
& =343,943(\text { 円) } \\
R_{2} !\left(N x_{2}\right) & =1.05 \times 3.0 \times 2,470,000 \times\left\{\left(\frac{2,000}{10,000}\right)^{\left(1+\frac{1}{3.0}\right)}-0.046416\right\}+343,943 \\
& =892,857 \text { (円) }
\end{aligned}
$$

$\alpha_{3}=\alpha_{4}$ であるから $R_{3}\left(N x_{3}\right)$ を省略して

$$
\begin{aligned}
R_{4}\left(N x_{4}\right) & =1.37 \times 3.0 \times 2,470,000 \times\left\{\left(\frac{4,000}{10,000}\right)^{\left(1+\frac{1}{3.0}\right)}-0.116966\right\}+892,857 \\
& =2,697,383 \text { (円) } \\
R_{5}\left(N x_{5}\right) & =1.46 \times 3.0 \times 2,470,000 \times\left\{\left(\frac{5,000}{10,000}\right)^{\left(1+\frac{1}{3.0}\right)}-0.294722\right\}+2,697,383 \\
& =3,802,287 \text { (可) }
\end{aligned}
$$

次に (3.25) 式より $L_{1}\left(N x_{1}\right)$ を求め, (3.29) 式に $L_{1}\left(N x_{1}\right)$ 执よび $R_{1}\left(N x_{1}\right)$ の值を大れて $X_{2}$ を求め (3.22) 式により $R_{2}\left(X_{2}\right)$ を求める。以下同様にして $X_{4}, X_{5}$ を求める。

(3.25) 式により

$$
\begin{aligned}
L_{1}\left(N x_{1}\right) & =(1+3.0) \times 0.1 \times 2,470,000 \\
& =988,000 \text { (円) }
\end{aligned}
$$

(3.29) 式により

$$
\begin{aligned}
X_{2} & =10,000 \times\left(1+\frac{1}{3.0}\right) \sqrt{\frac{2,470,000-1.05 \times 3.0 \times 2,470,000 \times 0.046416+343,943-988,000}{2.470,000\left\{1,05-\frac{1,000}{X_{2}}(1.05 \times 3+1.05)\right\}}} \\
& =9,710(\mathrm{hr})
\end{aligned}
$$

(3.22) 式より 


$$
\begin{aligned}
R_{2}\left(X_{2}\right) & =7,780.500 \times(0.961521-0.046416)+343,940 \\
& =7,463,214 \text { (円) }
\end{aligned}
$$

次に(3.26) 式より

$$
\begin{aligned}
L_{2}\left(N x_{2}\right) & =(7,463,214+2,470,000-988,000)\left(\frac{2,000-1,000}{9,710-1,000}\right)+988,000 \\
& =2,015,004 \text { (円) }
\end{aligned}
$$

(3.31）式より

$$
\begin{aligned}
X_{4} & =10,000 \times\left(1+\frac{1}{3.0}\right) \sqrt{\frac{2,470,000-1.37 \times 3.0 \times 2,470,000 \times 0.116966+892,857-2,015,004}{2,470,000 \times\left\{1.37-\frac{2,000}{X_{4}}(1.37 \times 3+1.37)\right\}}} \\
& =8,505(\mathrm{hr})
\end{aligned}
$$

(3.24) 式より

$$
\begin{aligned}
R_{4}\left(X_{4}\right) & =10,151,700 \times(0.80581-0.116966)+892,857 \\
& =7,885,955 \text { (门) }
\end{aligned}
$$

次に (3.28) 式により

(3.31）式より

$$
\begin{aligned}
L_{4}\left(N x_{4}\right) & =(7,885,995+2,470,000-2,015,004)\left(\frac{4,000-2,000}{8,505-2,000}\right)+2,015,004 \\
& =4,579,490 \text { (円) }
\end{aligned}
$$

\begin{tabular}{|c|c|c|c|c|}
\hline \multirow{2}{*}{\multicolumn{5}{|c|}{$\begin{array}{l}\text { 式…………松 D-50 購 入 } \\
\text { 㝤 入 価 格…………247 万円 (表-4.15 参照) }\end{array}$}} \\
\hline & & & & \\
\hline ........... & 0,000 時間 & $f$ & $\ldots \ldots \ldots \ldots+3.0$ & \\
\hline \multicolumn{5}{|c|}{ および $M x+\cdots \cdots \cdots \cdots \cdots$ 表一4.19 に示すと括りとする。 } \\
\hline & 表-4.19 & $\alpha$ および $M x$ & の 值 & \\
\hline & 購 入 年 度 & 1 次評佂後 & 再 評 価 後 & 再々評価後 \\
\hline $\begin{array}{l}\text { 物 価 指 数率 }(\alpha) \\
\text { 年度末むでの運転時間累計 }\end{array}$ & $\begin{array}{l}\alpha_{1}=1.00 \\
M x_{1}=1.000\end{array}$ & $\begin{array}{l}\alpha_{2}=1.05 \\
M x_{2}=2,000\end{array}$ & $\begin{array}{l}\alpha_{3}=1.37 \\
M x_{2}=4,000\end{array}$ & $\begin{array}{l}\alpha_{4}=1.46 \\
M x_{4}=5,000\end{array}$ \\
\hline
\end{tabular}

$$
\begin{aligned}
X_{5} & =10,000 \times \sqrt[\left(1+\frac{1}{3.0}\right)]{\frac{2,470,000-1.46 \times 3.0 \times 2,470,000 \times 0.294722+2,697,383-4,579,490}{2,470,000 \times\left\{1.46-\frac{4,000}{X_{5}}(1.46 \times 3+1.46)\right\}}} \\
& =8,345(\mathrm{hr})
\end{aligned}
$$

(3.24) 式より

$$
\begin{aligned}
R_{5}\left(X_{5}\right) & =10,818,600 \times(0.785661-0.294722)+2,697,383 \\
& =8,008,656 \text { (円) }
\end{aligned}
$$

時間当り使用料水 (3.32)〜 (3.35) 式により

$$
\begin{aligned}
l_{1}(x) & =(1+3.0) \times \frac{2,470,000}{10,000} \\
& =988(\text { 円 } / \mathrm{hr}) \\
l_{2}(x) & =7,463,214+2,470,000-988,000) \frac{1}{9,710-1,000} \\
& =1,027(\text { 円 } \mathrm{hr}) \\
l_{3}(x) & =l_{4}(x)=(7,835,995+2,470,000-2,015,004) \frac{1}{8,505-2,000} \\
& =1.275(\text { 円 } / \mathrm{hr}) \\
l_{5}(x) & =(8,008,656+2,470,000-4,579,490) \frac{1}{8,345 \sim 4,000} \\
& =1,358(\text { 円 } / \mathrm{hr})
\end{aligned}
$$

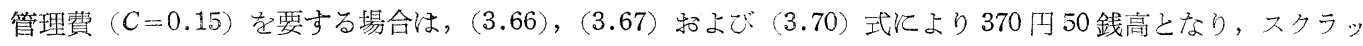
プ価格を計算に入れた場合は，約 49 円 50 銭安くなる。

\subsection{3. 購入価格を評価替えした場合}

計算例として 
以上の場合，計算例としては物価指数が変化した年度始めごとに評価替した場合と，別に最終の評価替のみ 1 回実施した場合について行ら。

\section{(1) 物価指数の変化に伴つて評価替した場合}

まづ (3.36) 式托よび (3.44) (3.46) 式により $R_{1}\left(M x_{1}\right), R_{2}\left(M x_{2}\right), \cdots \cdots R_{4}\left(M x_{4}\right)$ 至求わる。その計算は前項 に招いて計算して $R_{1}\left(N x_{1}\right), R_{2}\left(N x_{2}\right), R_{3}\left(N x_{3}\right)$ 拉よび $R_{4}\left(N x_{4}\right)$ に同じであるから

$$
\begin{array}{ll}
R_{1}\left(M x_{1}\right)=343,934(\text { 円) } & R_{2}\left(M x_{2}\right)=892,857 \text { (円) } \\
R_{3}\left(M x_{3}\right)=2,697,383 \text { (円) } & R_{4}\left(M x_{4}\right)=3,802,287 \text { (円) }
\end{array}
$$

次汇 (3.47) 式より $L_{1}\left(M x_{1}\right)$ を求め，(3.51) 式に $L_{1}\left(M x_{1}\right)$ 及び $R_{1}\left(M x_{1}\right)$ の值を入れて $X_{2}$ 是求め，(3.44）

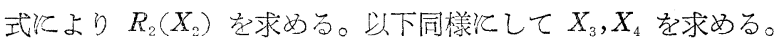

(3.47) 武边

$$
\begin{aligned}
L_{1}\left(M x_{1}\right) & =(1+3.0) \times 0.1 \times 2,470,000 \\
& =988,000(\text { 円 })
\end{aligned}
$$

(3.51) 式占り

$$
\begin{aligned}
X_{2} & =10,000 \times\left(1+\frac{1}{3.0}\right) \sqrt{\frac{1.05 \times 2,470,000-1.05 \times 3.0 \times 2,470,000 \times 0.046416+343,943-988,000}{\left\{1.05 \times\left(1+\frac{1}{3.0}\right)\left(1-\frac{1,000}{X_{2}}\right)-1.05\right\} \times 3.0 \times 2,470,000}} \\
& =10,100 \mathrm{hr})
\end{aligned}
$$

(3.44) 式より

$$
\begin{aligned}
R_{2}\left(X_{2}\right) & =1.05 \times 3.0 \times 2,470,000\left\{\left(\frac{10,100}{10,000}\right)^{\left(1+\frac{1}{3.0}\right)}-0.046416\right\}+343,943-(1.05-1.00) \times 2,470,000 \\
& =7,743,696 \text { (H) }
\end{aligned}
$$

(3.48) 式より

$$
\begin{aligned}
L_{2}\left(M x_{2}\right) & =(7,743,969+1.05 \times 2,470,000-988,000)\left(\frac{2,000-1,000}{10,100-1,000}\right)+988,000 \\
& =2,015,384 \text { (円) }
\end{aligned}
$$

(3.52) 式より

$$
\begin{aligned}
X_{3} & =10,000 \times\left(1+\frac{1}{3.0}\right) \sqrt{\frac{1.37 \times 2,470,000-1.37 \times 3.0 \times 2,470,000 \times 0.116966+892.857-2.015 .384}{\left\{1.37 \times\left(1+\frac{1}{3.0}\right)\left(1-\frac{2,000}{X_{3}}\right)-1.37\right\} \times 3.0 \times 2,470,000}} \\
& =11,060(\mathrm{hr})
\end{aligned}
$$

(3.45) 式卡り

$$
\begin{aligned}
R_{3}\left(X_{3}\right) & =1.37 \times 3.0 \times 2,470,000\left\{\left(\frac{11,060}{10,000}\right)^{\left(1+\frac{1}{3.0}\right)}-0.116966\right\}+892,857-(1.37-1.00) \times 2,470,000 \\
& =10,402,763(\mathrm{~F})
\end{aligned}
$$

(3.49) 式より

$$
\begin{aligned}
L_{3}\left(M x_{3}\right) & =10,402,763+1.37 \times 2,470,000-2,015,384)\left(\frac{4,000-2,000}{11,060-2,000}\right)+2,015,384 \\
& =4,613,875 \text { (H) }
\end{aligned}
$$

(3.53) 式より

$$
\begin{aligned}
X_{4} & =10,000 \times\left(1+\frac{1}{3.0}\right) \sqrt{\frac{1.46 \times 2,470,000-1.46 \times 3.0 \times 2,470,000 \times 0.294722+2,697,383-4,613,875}{\left\{1.46 \times\left(1+\frac{1}{3.0}\right)\left(1-\frac{4,000}{X_{4}}\right)-1.46\right\} \times 3.0 \times 2,470,000}} \\
& =12.095(\mathrm{hr})
\end{aligned}
$$

(3.46) 式より

$$
\begin{aligned}
R_{4}\left(X_{4}\right) & =1.46 \times 3.0 \times 2,470,000\left\{\left(\frac{12,095}{10,000}\right)^{\left(1+\frac{1}{3.0}\right)}-0.294722\right\}+2,697,383-(1.46-1.00) \times 2,470,000 \\
& =12,530,681 \text { (円) }
\end{aligned}
$$

時間当り使用料凉 (3.54) (3.57) 式飞より 


$$
\begin{aligned}
l_{1}(x) & =1.00(1+3.0) \times \frac{2,470,000}{10,000} \\
& =988(\text { 円 } / \mathrm{hr}) \\
l_{2}(x) & =(7,743,696+1.05 \times 2,470,000-988,000) \frac{1}{10,100+1,000} \\
& =1.150(\text { 円 } / \mathrm{hr}) \\
l_{3}(x) & =(10,402,763+1,37 \times 2,470,000-2,015,348) \frac{1}{11,060-2,000} \\
& =1,299(\text { 円 } / \mathrm{hr}) \\
l_{4}(x) & =(12,530,681+1.46 \times 2,470,000-4,613,991) \frac{1}{12,095-4,000} \\
& =1.423(\text { 円 } / \mathrm{hr})
\end{aligned}
$$

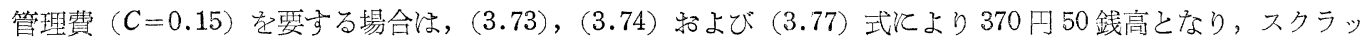
プ価格を計算に入れた場合は，約 49 円 50 銭安くなる。

(2) 最終の評価替の及 1 回実施した場合

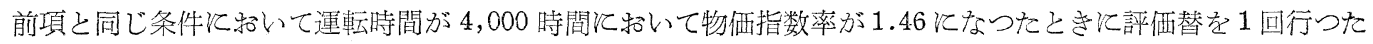
以後の使用料を算定する。

まず (3.36) 式とより

$$
\begin{aligned}
R_{1}\left(M x_{1}\right) & =1.00 \times 3.0 \times 2,470,000 \times\left(\frac{4,000}{10,000}\right)^{\left(1+\frac{4}{3.0}\right)} \\
& =2,183,890 \text { (円) }
\end{aligned}
$$

(3.47) 式より

$$
L_{1}\left(M x_{1}\right)=(1+3.0) \times \frac{4,000}{10,000} \times 2,470,000=3,952,000 \text { (円) }
$$

(3.51) 式より

$$
\begin{aligned}
& X_{2}=10,000 \times \sqrt{\frac{\left.1+\frac{1}{3.0}\right)}{\frac{1.46 \times 2,470,000-1.46 \times 3.0 \times 2,470,000 \times\left(\frac{4,000}{10,000}\right)^{\left(1+\frac{1}{3.0}\right)}+2.183,890-3,952,000}{\left\{1.46 \times\left(1+\frac{1}{3.0}\right)\left(1-\frac{4,000}{X_{2}}\right)-1.46\right\} \times 3.0 \times 2,470,000}}} \\
& X_{2}=12,525(\mathrm{hr})
\end{aligned}
$$

(3.44) 式より

$$
\begin{aligned}
R_{2}\left(X_{2}\right) & =1.46 \times 3.0 \times 2,470,000 \times\left\{\left(\frac{2,525}{10,000}\right)^{\left(1+\frac{1}{3.0}\right)}-0.294722\right\}+2,183,890(1.46-1.00) \times 2,470,000 \\
& =11,926,211 \text { (円) }
\end{aligned}
$$

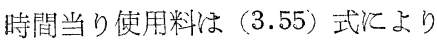

$$
\begin{aligned}
l_{2}(x) & =(11,926,211+1.46 \times 2,470,000-3,952,000) \frac{1}{12,525-4,000} \\
& =1,358(\text { 円 } / \mathrm{hr})
\end{aligned}
$$

\subsection{4. 同一型式で購入年度の異なる場合の使用料の比較}

前各項の計算例と同一型式である。小松 D-50 型ブルドーザの各購入年度別のものとついて，使用料を算定し相 互の比較をするととにより，使用料の特異性を調べる。

対象とする小松 D-50 型结表一 4.11 亿示す $f$ の値と表一 4.15 江示す購入価格を用い， $X=10,000$ 時間とす る。各購入年度別使用料は (3.81) 式汇より次のように求められる。

(1) 24 年度購入 (D-50 型)

$$
\begin{aligned}
& P=247 \text { 万円 } f=3.0 \\
& C=0.15 \quad P_{s} / P=0.02 \\
& l(x)=\left\{(1+3.0-0.02) \times \frac{1}{10,000}+\frac{0.15}{1,000}\right\} \times 2,470,000 \\
& =1.354(\text { 円 } / \mathrm{hr})
\end{aligned}
$$


(2) 25 年度購大 (D-50 型)

$$
\begin{array}{ll}
P=260 \text { 万円 } & f=2.7 \\
C=0.15 & P_{s} / P=0.02 \\
l(x)=\left\{(1+2.7-0.02) \times \frac{1}{10,000}+\frac{0.15}{1,000}\right\} \times 2,600,000 \\
\quad=1,347(\text { 円 } / \mathrm{hr})
\end{array}
$$

(3) 26 年度挌よび 27 年度購入 (D-50 型)

$$
\begin{array}{ll}
P=340 \text { 万円 } & f=2.4 \\
C=0.15 & P_{s} / P=0.02 \\
l(x)=\left\{(1+2.4-0.02) \times \frac{1}{10,000}+\frac{0.15}{1,000}\right\} \times 3,400,000 \\
\quad=1,659(\text { 円 } / \mathrm{hr})
\end{array}
$$

\begin{tabular}{|c|c|c|c|c|c|c|c|c|}
\hline 緬入年度 & 物価または評価の扱い方 & 24 & 年 度 & 25 & 年 度 & 26,27 年度 & 28 & 年. 度 \\
\hline \multirow{4}{*}{ 年 度 } & 毎年修理費の物価変動老考えた & & 1,309 & & 1,348 & 1,596 & & 1,679 \\
\hline & 每年購入価格の評価替えをした & & 1,309 & & 1,470 & 1,620 & & 1,744 \\
\hline & 28 年度頭初の2評価替えした & \multicolumn{5}{|c|}{1,309} & & 1,679 \\
\hline & 物価評価の変動を考えない & \multicolumn{7}{|c|}{1,354} \\
\hline 25 年 度 & 物価, 評価の変動老考无い & & - & \multicolumn{5}{|c|}{1,347} \\
\hline 26,27 年度 & $"$ & \multicolumn{4}{|c|}{-} & \multicolumn{3}{|c|}{1,659} \\
\hline 28 年 度 & $"$ & & & & - & & & 1,685 \\
\hline
\end{tabular}

(4) 28 年度購入 (D-50 型)

$$
\begin{aligned}
& P=360 \text { 万円 } f=2.2 \\
& C=0.15 \quad P_{s} / P=0.02 \\
& l(x)=\left\{(1+2.2-0.02) \times \frac{1}{10,000}+\frac{0.15}{1.000}\right\} \times 3,600,000 \\
& =1.685(\text { 円 } / \mathrm{hr})
\end{aligned}
$$

（5）同一型式のブルドーザそついての使用料の比較

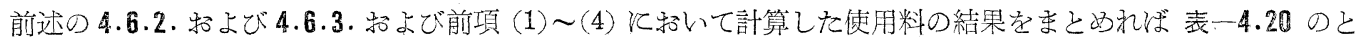
拉り，

表一4.20 小松 D-50 の使用料の比較（単位. 四 $/ \mathrm{hr}$ )

$$
\left(C=0.15 P_{s} / P=0.02 \quad \bar{N} x=1,000 \mathrm{hr}\right)
$$

\section{7. 修理費の計算}

\subsection{1. 修 理 費 率}

ブルドーザの修理費（定期整供を含も）の計算は経济的酎用時間 $X$ を 10,000 時間とし， $f$ の值を表一 4.11 招 よび表一4.12 とより選定し，(3.5) 式を使用して計算すれば求められる。

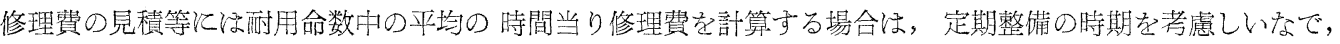
(3.5) 式により求めることができるが，定期的全分解整備の費用を見積つたり，定期整備直後より次の定期整備 までの修理費を計算する場合，定期整備の時期を考虑して (3.5) 式とより算定して值を補正して求める必要があ る。いら゙れも購入費 (時価) を基として，そにある係数を束じると修理費が求められる方法により，との係数すな わち修理費率を型式別汇定めて括くと便利である。

従つて修理費率は定期整備を考慮しない場合と，考慮する場合と別個と算定して括く必要があり，次治説明す る。

（1）定期整備の時期起考慮しない場合

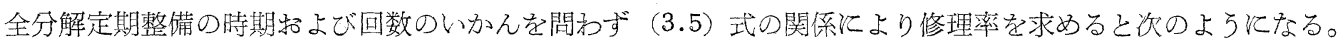
ある任意時間污ける修理費の罢計沈次の式により求める。

$$
x_{1} \text { より } x_{2} \text { 時間までの修理費の䍗計 }=R\left(x_{2}\right)-R\left(x_{1}\right)
$$

める任意時間江和汗る平均時間当り修理費纺次の式により求める。 
$x_{1}$ より $x_{2}$ 時間に和忷る時間当り平均修理費 $=\frac{R(x)-R\left(x_{1}\right)}{x_{2}-x_{1}}$

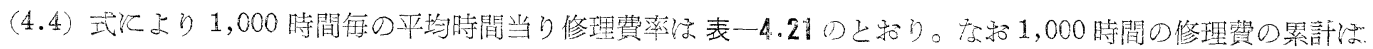

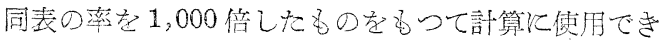
๖。

\section{（2）定期整備老考慮した場合}

修理費注定期整備を考慮すれば図一3.2 亿示したよ ろに階段状に増加し，(3.5) 式の修理費累計曲線合 致しない。この場合，使用中活等間隔に一定の渾転時 間が経過したとき亿何回かの全分解整借を実㧾し，艺 の定期整備費の割合注 (3.5) 式泀より示す修理費の增

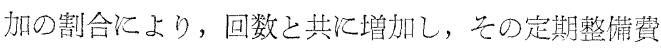
の何割かの現場小修理が同様に (3.5) 式の割合で要す るものと落光る。李た機械を経済的耐用時間で廃童す 表 -4.21 時間当り修理費率 $\left(\times 10^{-6}\right)$

\begin{tabular}{r|r|r|r|r|r|r|r|r}
\hline & \multicolumn{9}{|c|}{$f$} \\
\hline & 1.1 & 1.3 & 1.5 & 1.7 & 1.8 & 2.0 & 2.2 & 2.4 \\
\hline $0 \sim 1,000$ & 14 & 22 & 32 & 44 & 50 & 63 & 77 & 92 \\
\hline $1,000 \sim 2,000$ & 37 & 53 & 70 & 88 & 97 & 116 & 135 & 153 \\
$2,000 \sim 3,000$ & 60 & 79 & 99 & 119 & 129 & 150 & 170 & 191 \\
$3,000 \sim 4,000$ & 81 & 103 & 124 & 145 & 156 & 177 & 198 & 219 \\
$4,000 \sim 5,000$ & 102 & 124 & 147 & 169 & 180 & 202 & 223 & 244 \\
$5,000 \sim 6,000$ & 123 & 145 & 168 & 190 & 201 & 223 & 244 & 265 \\
$6,000 \sim 7,000$ & 141 & 165 & 188 & 210 & 221 & 242 & 263 & 284 \\
$7,000 \sim 8,000$ & 162 & 193 & 207 & 229 & 239 & 260 & 281 & 302 \\
$8,000 \sim 9,000$ & 181 & 204 & 225 & 246 & 256 & 277 & 298 & 318 \\
$9,000 \sim 10,000$ & 200 & 222 & 241 & 260 & 271 & 291 & 312 & 333 \\
\hline
\end{tabular}

るるのとして，最後の定期整備より廃棄までね現場小修理のみが必恶であるとした。

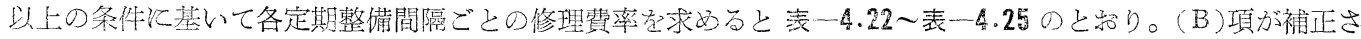
れた修理費率であり，(A) 項注定期整供を考慮しない場合の（4.3）式により求めた修理費率である。この計算は

(例 4 ） 飞との方法走示して岁る。

表-4.22 定期整備 2 回 (3,330 時間ご亡) の場合の修理費率

\begin{tabular}{r|c|c|c|c|c|c|c|c}
\hline \multirow{2}{*}{$x_{1} \sim x_{2}$} & \multicolumn{2}{|c|}{$f=1.5$} & \multicolumn{2}{|c|}{$f=1.7$} & \multicolumn{2}{|c|}{$f=2.0$} & \multicolumn{2}{c|}{$f=2.2$} \\
\cline { 2 - 9 } & (A) & (B) & (A) & (B) & (A) & (B) & (A) & (B) \\
\hline $0 \sim 3,330$ & 0.240 & 0.432 & 0.297 & 0.521 & 0.385 & 0.656 & 0.444 & 0.747 \\
$3,330 \sim 6,660$ & 0.523 & 0.942 & 0.596 & 1.045 & 0.704 & 1.198 & 0.775 & 1.301 \\
$6,660 \sim 10,000$ & 0.737 & 0.126 & 0.807 & 0.134 & 0.911 & 0.146 & 0.981 & 0.152 \\
\hline 補正率 (A)/(B) & \multicolumn{2}{|c|}{$55.5 \%$} & \multicolumn{2}{|c|}{$57.0 \%$} & \multicolumn{2}{|c|}{$58.7 \%$} & \multicolumn{2}{c|}{$59.4 \%$} \\
\hline
\end{tabular}

(注) 1. (A) $=f \cdot\left(\frac{x_{2}}{X}\right)^{\left(1+\frac{1}{f}\right)}-f\left(\frac{x_{1}}{X}\right)\left(1+\frac{1}{f}\right)$ (四一-4.4に和いて実線て示

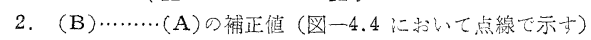

表一 4.23 定期整備 4 回 $(2,000$ 時間ごと) の場合の修理費率

\begin{tabular}{|c|c|c|c|c|c|c|c|c|}
\hline \multirow{2}{*}{$x_{1} \sim x_{2}$} & \multicolumn{2}{|c|}{$f=1.5$} & \multicolumn{2}{|c|}{$f=1.7$} & \multicolumn{2}{|c|}{$f=2.0$} & \multicolumn{2}{|c|}{$f=2.2$} \\
\hline & (A) & (B) & (A) & (B) & (A) & (B) & (A) & (B) \\
\hline $0 \sim 2,000$ & 0.103 & 0.143 & 0.132 & 0.181 & 0.179 & 0.241 & 0.212 & 0.283 \\
\hline $2,000 \sim 4,000$ & 0.223 & 0.311 & 0.264 & 0.362 & 0.327 & 0.440 & 0.368 & 0.492 \\
\hline $4,000 \sim 6,000$ & 0.314 & 0.437 & 0.359 & 0.492 & 0.425 & 0.573 & 0.457 & 0.621 \\
\hline $6,000 \sim 8,000$ & 0.394 & 0.549 & 0.439 & 0.602 & 0.502 & 0.676 & 0.544 & 0.727 \\
\hline $8,000 \sim 10,000$ & 0.466 & 0.060 & 0.506 & 0.062 & 0.568 & 0.070 & 0.610 & 0.075 \\
\hline 竍正率 $(\mathrm{A}) /(\mathrm{B})$ & \multicolumn{2}{|c|}{$71.8 \%$} & \multicolumn{2}{|c|}{$73.0 \%$} & \multicolumn{2}{|c|}{$74.2 \%$} & \multicolumn{2}{|c|}{$75.0 \%$} \\
\hline
\end{tabular}

(注) $\frac{1}{2}$. $\}$ 表-4.22 红同じ

表一 4.24 定期整備 6 回 $(1,430$ 時間ごし) の場合の修理費率

\begin{tabular}{|c|c|c|c|c|c|c|c|c|}
\hline \multirow{2}{*}{$x_{1} \sim x_{2}$} & \multicolumn{2}{|c|}{$f=1.5$} & \multicolumn{2}{|c|}{$f=1.7$} & \multicolumn{2}{|c|}{$f=2.0$} & \multicolumn{2}{|c|}{$f=2.2$} \\
\hline & (A) & (B) & (A) & (B) & (A) & (B) & (A) & (B) \\
\hline $0 \sim 1,430$ & 0,058 & 0.073 & 0.078 & 0.097 & 0.108 & 0.133 & 0.130 & 0.159 \\
\hline $1,430 \sim 2,860$ & 0,127 & 0.160 & 0.146 & 0.182 & 0.197 & 0.242 & 0.214 & 0.262 \\
\hline $2,860 \sim 4,285$ & 0,181 & 0.228 & 0.219 & 0.272 & 0.256 & 0.315 & 0.297 & 0.364 \\
\hline $4,285 \sim 5,715$ & 0.224 & 0.282 & 0.256 & 0.319 & 0.303 & 0.373 & 0.334 & 0.409 \\
\hline $5,715 \sim 7,140$ & 0.266 & 0.335 & 0.298 & 0.372 & 0.343 & 0.423 & 0.375 & 0.460 \\
\hline $7,140 \sim 8,570$ & 0.304 & 0.383 & 0.333 & 0.415 & 0.380 & 0.468 & 0.405 & 0.496 \\
\hline $8,570 \sim 10,000$ & 0.340 & 0.039 & 0.370 & 0.045 & 0.413 & 0.046 & 0.445 & 0.050 \\
\hline 補正率 (A)/(B) & \multicolumn{2}{|c|}{$79.3 \%$} & \multicolumn{2}{|c|}{$80.2 \%$} & \multicolumn{2}{|c|}{$81.2 \%$} & \multicolumn{2}{|c|}{$81.6 \%$} \\
\hline
\end{tabular}

(注) $\begin{aligned} & 1 . \\ & 2 .\end{aligned}$ 表-4.22 汇同し 
表-4.25 定期整備 9 回 (1,000 時間ごと) の場合の修理費率

\begin{tabular}{|c|c|c|c|c|c|c|c|c|c|}
\hline \multirow{2}{*}{\multicolumn{2}{|c|}{$x_{1} \sim x_{2}$}} & \multicolumn{2}{|c|}{$f=1.5$} & \multicolumn{2}{|c|}{$f=1.7$} & \multicolumn{2}{|c|}{$f=2.0$} & \multicolumn{2}{|c|}{$f=2.2$} \\
\hline & & (A) & (B) & (A) & (B) & (A) & (B) & (A) & (B) \\
\hline 0 & $\sim 1,000$ & 0.032 & 0.037 & 0.044 & 0.051 & 0.063 & 0.072 & 0.077 & 0.088 \\
\hline 1,000 & $\sim 2,000$ & 0.070 & 0.082 & 0.088 & 0.102 & 0.116 & 0.133 & 0.135 & 0.155 \\
\hline 2,000 & $\sim 3,000$ & 0.099 & 0.116 & 0.119 & 0.138 & 0.150 & 0.172 & 0.170 & 0.195 \\
\hline 3,000 & $\sim 4,000$ & 0.124 & 0.145 & 0.145 & 0.169 & 0.177 & 0.204 & 0.198 & 0.227 \\
\hline 4,000 & $\sim 5,000$ & 0.147 & 0.171 & 0.169 & 0.196 & 0.202 & 0.233 & 0.223 & 0.256 \\
\hline 5,000 & $\sim 6,000$ & 0.168 & 0.197 & 0.190 & 0.221 & 0.223 & 0.257 & 0.244 & 0.279 \\
\hline 6,000 & $\sim 7,000$ & 0.188 & 0.220 & 0.210 & 0.244 & 0.242 & 0.279 & 0.263 & 0.301 \\
\hline 7,000 & $\sim 8,000$ & 0.207 & 0.243 & 0.229 & 0.266 & 0.260 & 0.300 & 0.281 & 0.322 \\
\hline 8,000 & $\sim 9,000$ & 0.225 & 0.264 & 0.246 & 0.286 & 0.277 & 0.319 & 0.298 & 0.341 \\
\hline 9,000 & $\sim 10,000$ & 0.241 & 0.025 & 0.260 & 0.027 & 0.290 & 0.031 & 0.312 & 0.036 \\
\hline 補正率 & $(\mathrm{A}) /(\mathrm{B})$ & \multicolumn{2}{|c|}{$85.2 \%$} & \multicolumn{2}{|c|}{$85.9 \%$} & \multicolumn{2}{|c|}{$86.7 \%$} & \multicolumn{2}{|c|}{$87.3 \%$} \\
\hline
\end{tabular}

(注) $\left.\begin{array}{l}1 . \\ 2 .\end{array}\right\}$ 表 -4.22 江同

図一4.5立 (A) と (B) の関係を図示 乙た 1 例で,定期整備 4 回 $(2,000$ 時間ご と）で $f=1.7$ の場合を示す。この図汇 扮いて注現場小修理費を定期整備費の 1 割と乙た。

図一4.6に(A)と(B)との割合，すな わち補正率が経済的而用時間李での全分 解定期整備回数招よび $f$ の值汪よる变化 を示するので, 表一 4.22 表-4.25 亿示 されていない修理費率を求める際浭利 である。

4.7.2. 修理費つ見皘り計算

標準的な作業条件で使用されたブルド 一ザのある期間の修理費また注全分解定 期整備費を見積する場合は 表一4.11 あ るいは 表一4.12 とより使用されたブル ドーザの $f$ を定め，そのブルドーザの価
図-4.5

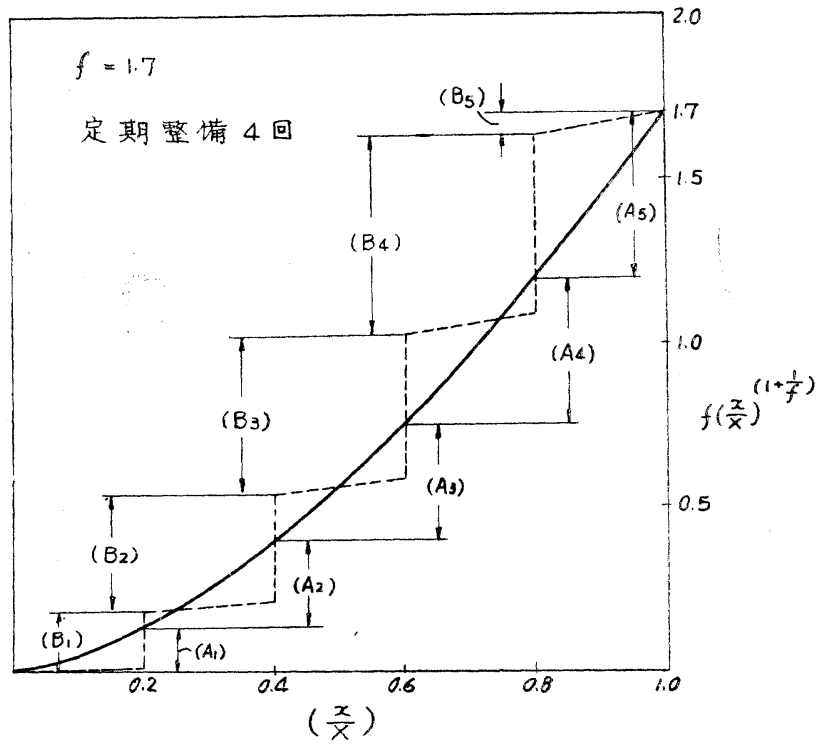

図-4.6

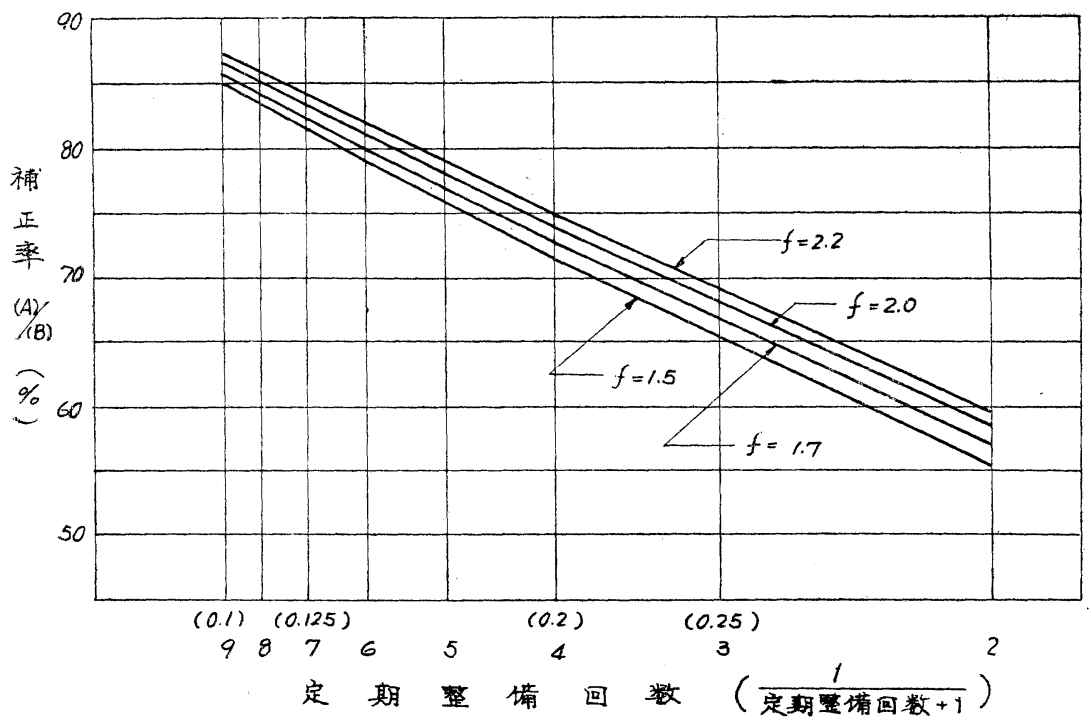




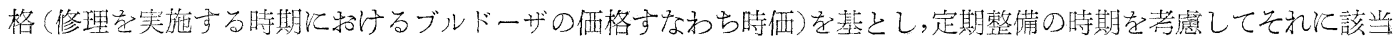
する表一4.22〜表一4.25の(B)の修理費率を用いるか，(3.5) 式秥よび（4.3）式とより予定された運転時間まで の修理費の累計を計算し，図一 4.5 の補正率 $(A) /(B)$ を用いて算出する。かくして求められた修理費は定期整備 費之現場小修理を加えたものであるから，定期整備を見積る場合は乞の中から現場小修理分を除いたるのとする。

(例 1 ) 定期整借費の見積り（その1)

昭和 28 年度製小松 D-50 型ブルドーザを道路土工作業に 1,430 時間（運転時間）使用した後の初回の全分解定 期整備の見積りほ次の計算となる。

$$
\begin{aligned}
& \text { 定期整備実施時期 …………昭和 } 29 \text { 年度 } \\
& \text { 昭和 } 29 \text { 年度購入価格………3 } 800,000 \text { 江 }
\end{aligned}
$$

とすると表一4.24 亿より

$$
\begin{aligned}
R(x) & =3,800,000 \times 0.159 \\
& =604,200 \text { (円) }
\end{aligned}
$$

次汇定期整倩費の 1 割の現場小修理費分を差引いて

$$
604,200 \times \frac{1.0}{1.1}=549,270 \text { (円) }
$$

\section{(例 2 ) 定期整備の見積り（その2）}

昭和 29 年度製三菱日本 $\mathrm{BF}$ 型ブルドーザを河川の掘削工事に 2,000 時間（運転時間）使用して，全分解整備を 実施した後 1,500 時間築堤の盛土作業充当して後, 再び全分解定期整储する場合の整備費の見積りは次の計算 となる。

$$
\begin{aligned}
& \text { 再定期整備実施時期 ………昭和 } 30 \text { 年度 } \\
& \text { 昭和 } 30 \text { 年度購入価格………6, } 450,000 \text { 円 (表 }-4.10 \text { 参照) }
\end{aligned}
$$

とすると，(4.3) 式とより

$$
\begin{aligned}
R\left(x_{2}\right)-R\left(x_{1}\right) & =6,450,000 \times 1.7 \times\left\{\left(\frac{2,000+1,500}{10,000}\right)^{\left(1+\frac{1}{1.7}\right)}-\left(\frac{2,000}{10,000}\right)^{\left(1+\frac{1}{1.7}\right)}\right\} \\
& =1,218,820 \text { (円) }
\end{aligned}
$$

次飞図一 4.6 亿より $f=1.7,1,500$ 時間定期整備の場合の補正率は $79 \%$ であり，かつ現場小修理費を定期整 借費の $10 \%$ としてこれを差引けげ

$$
1,218,820 \times \frac{1.0}{0.79} \times \frac{1.0}{1.1}=1.517,740 \text { (円) }
$$

(例 3) 修理費の見積り（その1）

昭和 28 年度製小松 D-80 型ブルドーザを河川築是工事に 1,430 時間使用し, 初回の全分解定期整備をした後再 び河川築堤工事に 2,500 時間使用する。後の 2,500 時間の作業印飞必要とする修理費を求める。ただし 2,860 時 間目に括いて第 2 回目の全分解定期整備を実施するものとする。この場合第 2 回目の全分解定期整備が使用中に 起るが，この全分解定期整備後の運転時間が負担する次回の全分解定期整備の負担分も含むるのとする。

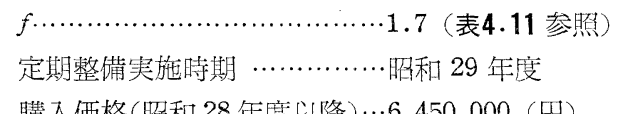

とすると表一 4.24 とより

$$
\left(182+272 \times \frac{2,500-1,430}{1,430}\right) \times 6,450,000 \times 10^{-3}=2,480,000 \text { 円 }
$$

この間和ける平均時間当り修理費は

$$
\frac{2,480,000}{2,500}=992(\text { 円 } / \mathrm{hr})
$$

(例 4) 修理費の見積り（その2)

昭和 29 年度に輸入した D-8 ブルドーザを使用して昭和 30 年 4 月より 3 ケ年間，アースダム工事の採取土の削 土作業彷事する場合の毎年必要とする修理費を算出する。ただし年間運転時間は 1,110 時間とし，この作業の 
終了後全分解整備をするものとし，この全分解整備の費用もこれ含むるのとする。またこの間路ける物価の 変動はないものとする。

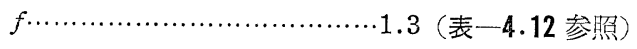

$$
\begin{aligned}
& \text { 購 入 洒 格 …………1..10,700,000 円 (4.4.3 参照) }
\end{aligned}
$$

とすると, 表一 4.22 ( 3,330 時間ごとの定期整䜤の修理費率表) 飞 $f=1.3$ の場合の修理費率が計上されていない ため定期整供を考慮した場合の修理費の計算を行う。

(3.5) 式により $x_{1}=3,300(\mathrm{hr}), x_{2}=6,670(\mathrm{hr}), X=10,000(\mathrm{hr})$

$$
\begin{aligned}
R\left(x_{1}\right)=10,700,000 \times 1,3 \times\left(\frac{3,330}{10,000}\right)^{\left(1+\frac{1}{1.3}\right)} & \\
=1,990,000 \text { (円) } & \\
R\left(x_{2}\right)-R\left(x_{1}\right) & =10,700,000 \times 1.3\left\{\left(\frac{6,670}{10,000}\right)^{\left(1+\frac{1}{1.3}\right)}-\left(\frac{3,330}{10,000}\right)^{\left(1+\frac{1}{1.3}\right)}\right\} \\
& =4,800,000 \text { (円) } \\
R(X)-R\left(x_{2}\right) & =10,700,000 \times 1.3-1,990,000-4,8000,000 \\
& =7,120,000 \text { (円) }
\end{aligned}
$$

10,000 時間に和いては定期整備をしないから $R\left(x_{1}\right)$ 招よび $R\left(x_{2}\right)-R\left(x_{1}\right)$ を補正して，

$$
\begin{aligned}
R^{\prime}\left(x_{1}\right) & =\left(10,700,000 \times 1.3-7,120,000 \times \frac{0.1}{1.1}\right) \times \frac{1,990,000}{1,990,000+4,800,000} \\
= & 3,888,080 \text { (円) } \\
R^{\prime}\left(x_{2}\right)-R^{\prime}\left(x_{1}\right) & =\left(10,700,000 \times 1.3-7,120,000 \times \frac{0.1}{1.1}\right) \times \frac{4,800,000}{1,990,000+4,800,000} \\
& =9,378,280 \text { (円) }
\end{aligned}
$$

2 回目の定期整備以後経済的而用時間までの現場小修理費として

$$
9,378,280 \times \frac{0.1}{1.1} \times \frac{7,120,000}{4,800,000}=1,264,640 \text { (円) }
$$

従つて再び $R\left(x_{1}\right)$ 抒よび $R\left(x_{2}\right)-R\left(x_{1}\right)$ を補正して

$$
\begin{aligned}
R^{\prime \prime}\left(x_{1}\right) & =(10,700,000 \times 1.3-1,264,640) \times \frac{1,990,000}{1,990,000+4,800,000} \\
= & 3,706,070 \text { (円) } \\
R^{\prime \prime}\left(x_{2}\right)- & R^{\prime \prime}\left(x_{1}\right)=(10,700,000 \times 1.3-1.264,640) \times \frac{4,800,000}{1,990,000+4,800,000} \\
= & 8,939,280 \text { (円) }
\end{aligned}
$$

すなわち 3,330 時間の定期整備までの修理費累計は 3,706,070 円である。このちち現場小修理費を定期整備費の 1 割として, 足回りの磨籷に対する補修は 3,330 時間の定期整備まで実施しないものとすると, 現場小修理費は

$$
3,706,070 \times \frac{0.1}{1.1}=336,910 \text { (円) }
$$

すなわち 336,910 円 が 3 年間の現場小修理費であるため，(3.5) 式を用い 1,110 時間ごとの修理費の比率を算定 すると，

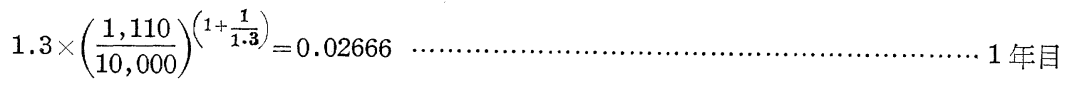

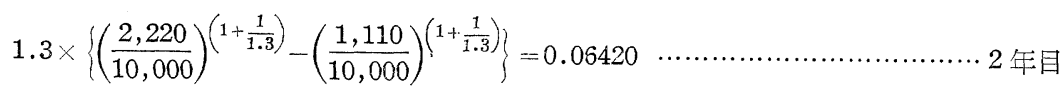

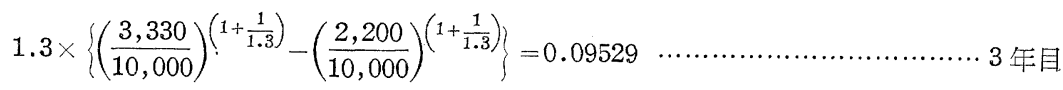

以上の比率注り各年の現小場修理費を配分すると，

$$
\begin{aligned}
& 1 \text { 年目 } 336,910 \times \frac{2,666}{2,666+6,420+9,529}=48,240 \text { (円) } \\
& 2 \text { 年目 } 336,910 \times \frac{6,420}{2,666+6,420+9,529}=115,870 \text { (円) }
\end{aligned}
$$


3 年目 $386,910 \times \frac{9,529}{2,666+6,420+9,529}=172,800$ (円)

3 年目はこの他淀期整備として

$$
3,706,070-336,910=3,369,160 \text { (円) }
$$

\section{第 5 章 工費および工期の算定}

\section{1. 概 説}

ブルドーザ土工の作業設計の算定を行う場合に, 従来は土工量 $100 \mathrm{~m}^{3}$ 当りの燃料, 油脂消費量㐨よび労力歩掛 り等の作業歩掛りの実績値を求めて执いて，これらを基準として総土工量に対する所要量を算定している。この 方法によれば設計の際に計算した所要量と実績量の数值が甚だしく開きを生じた実例が多く設計の信頼性が失わ れる結果を招く場合が多い。

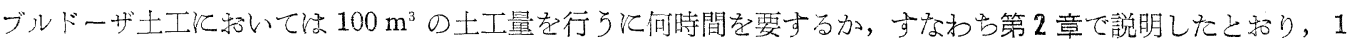
時間何立方米の土工量を施工できるかを判定することが最も困難であつて，その反対にブルドーザの運転の単 位時間に消費する燃料, 油脂, 労力等の所要量々主としてブルドーザの機械的条件に基いて定まるもので, 現場 条件飞左右されることが少い。

従つてこの土工設計々算沉括いて $100 \mathrm{~m}^{3}$ 当りの単価表を用いるより，1 時間当りの消費量と 1 時間の土工量を その都度区分して考学る計算によることにより始めて信頼性の高い設計が可能である。

総工費を求めるには総土工量を作業するそ要する所要時間を計算し, これて 1 時間当りの工費単価を掛讨, そ

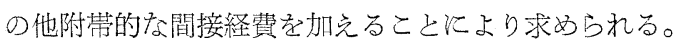

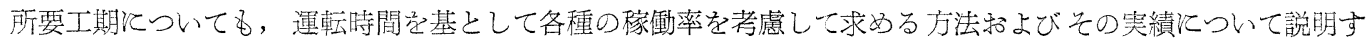
る。

\section{2. 時間当り燃料消費量の実績}

各型式についての燃料等の消費実績は，建設省，農林省，日本国有鉄道に括ける機械化施工現場の調查実績を

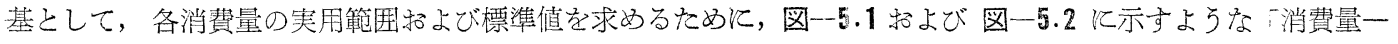
回数」のグラフにとつて確率曲線そ描く。

図一5.1 国産ブルドーザ主燃料消費量確率曲線

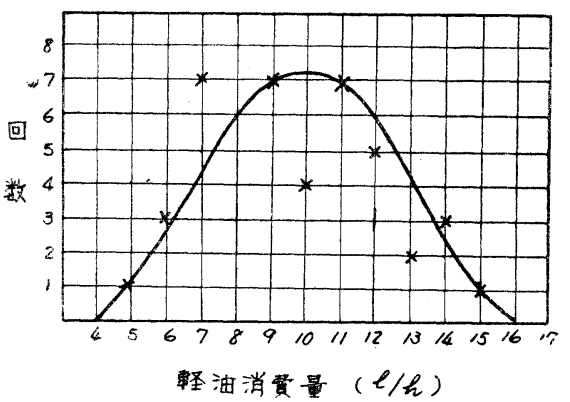

困一5.2 D-7 ブルドーザ主燃料消費量磪率曲線

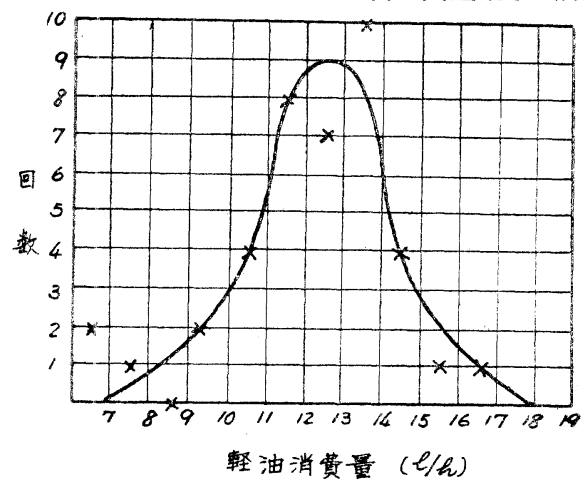

実績の乏しい型式括よび実績のない型式の主燃料の消費量を求めるには，実績の富豊な型式の主然料消費実績 を基として，これそ定格馬力に括ける両者の時間当り主燃料消費量の比率を用いて換算する方法によつた。

覀た国産ブルドーザについて，D-50，BBIII，NTK-7 の主然料の時間当り消費実績を表一5.1 亿示す主燃料消

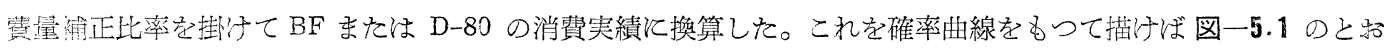
りとなり，消費量の標準值を知ることができる。キャタピラーD-7 については資料数 41 を数克るために単独で

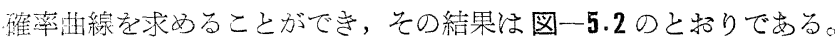

この2つの確率曲線の5方，国産ブルドーザ確率曲線の山形が鈍い形沈なているのは補正を行つを際，若干 
のずれを生じた結果であろう。従つて図一5.2のと和り D-7 1 型式のみにて主燃料消費量確率曲線を描けば山形

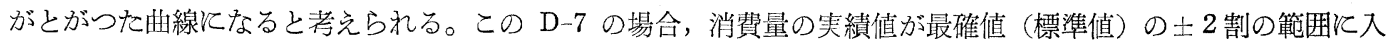
るものは，資料数 41 のち33すなわち $80 \%$ あるの で, 主燃料の標準值と対して上2 割の範囲を実用値と してとの実用範囲を示すこととした。まててのとき確 率曲線は消費量の增大する方向に括いては，定格馬力 を負荷した連続運転に和ける消費量を限界として理論 的に零となるべきである。

以上の整理を行つてブルドーザ各型式についての 1 時間当り燃料油脂消費量を求めれば，表一 5.2 のと招 り。

表一5.1 国産ブルドーザの燃料消費補正率表

\begin{tabular}{|c|c|c|c|c|c|}
\hline 型 & 式 & 資 料 数 & 定格馬力 & $\begin{array}{c}\text { 主燃料消費量 } \\
(\mathrm{g} / \mathrm{h})\end{array}$ & 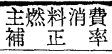 \\
\hline 日 & 特 NTK-4 & 0 & 46 & 9,200 & 2.065 \\
\hline 小 & 松 D-50 & 13 & 55 & 10,725 & 1.771 \\
\hline$\equiv$ & 菱 B B III & 11 & 65 & 13,650 & 1.391 \\
\hline$\equiv$ & 菱 B B IV & 0 & 80 & 15,200 & 1.250 \\
\hline 日 & 特 NTK-7 & 7 & 85 & 17,000 & 1.117 \\
\hline$\Xi$ & 菱 $\quad$ B F & 9 & 100 & 19,000 & 1.000 \\
\hline 小 & 松 D-80 & 9 & 100 & 19,000 & 1.000 \\
\hline 小 & 松 D-120 & 0 & 150 & 28,500 & 0.667 \\
\hline
\end{tabular}

表一5.2 ブルドーザ 1 時間当り燃料油脂消費量

\begin{tabular}{|c|c|c|c|c|c|c|c|c|c|c|c|c|c|c|}
\hline & & & & $\begin{array}{l}\text { 単 } \\
\text { 位 }\end{array}$ & $\mid \begin{array}{c}\text { キ } \\
\mathrm{D}-8\end{array}$ & $\mid \begin{array}{c}\text { キタ タ゚ラ } \\
\mathrm{D}-7\end{array}$ & $\begin{array}{c}\text { 小 } \\
\text { D }-120^{\text {松 }}\end{array}$ & 小 $\mathrm{D}-80^{\text {松 }}$ & $\equiv_{\mathrm{B} \mathrm{F}}$ & 日 $\mathrm{NTK}-7^{\text {特 }}$ & $\left.\right|_{\text {B B IV }} ^{\text {菱 }}$ & $\mid$\begin{tabular}{|} 
B B III \\
菱
\end{tabular} & 小 & $\begin{array}{l}\text { 日 特 } \\
\text { NTK }-4\end{array}$ \\
\hline 軽 & & & 油 & $l$ & $\stackrel{14}{(11 \sim 17)}$ & $\begin{array}{c}12.5 \\
(10 \sim 15)\end{array}$ & $\begin{array}{c}15 \\
\left(12^{2}-18\right)\end{array}$ & $\stackrel{10}{(8 \sim 12)}$ & $\begin{array}{c}10 \\
(8-12)\end{array}$ & $\begin{array}{c}8.5 \\
(6.5 \sim 10.5)\end{array}$ & $\begin{array}{c}7 \\
(5.5 \sim 8.5)\end{array}$ & $\begin{array}{c}6 \\
(4.5 \sim 7.5)\end{array}$ & $\begin{array}{c}5 \\
(4 \sim 6)\end{array}$ & $\stackrel{4}{(3 \sim 5)}$ \\
\hline カ & Y & リ & ン & $l$ & 0.30 & 0.25 & 0.30 & 0.20 & 0.20 & $(0.01)$ & $(0,01)$ & $(0.01)$ & 0.15 & $(0.01)$ \\
\hline モ & ビ & - & ル & $l$ & 0.70 & 0.60 & 0.70 & 0.50 & 0.50 & 0.40 & 0.35 & 0.30 & 0.25 & 0.20 \\
\hline 平 & $ヤ$ & - & 油 & $l$ & 0.46 & 0.35 & 0.40 & 0.30 & 0.30 & 0.30 & 0.30 & 0.25 & 0.25 & 0.20 \\
\hline $\mathscr{J}$ & y & - & ス & $\mathrm{kg}$ & 0.25 & 0.20 & 0.25 & 0.20 & 0.20 & 0.15 & 0.15 & 0.15 & 0.15 & 0.15 \\
\hline ウ & & I & ス & $\mathrm{kg}$ & \multicolumn{10}{|c|}{$0.02 \sim 0.05$} \\
\hline
\end{tabular}

（註）1. 1 時間とはブルト゚ーザが工事場にある間の運転時間をいい，実作業時間ではない。

2. 表の数值は各消費量の標準值を示すもので, 実用值は作業の変化によって適宜加減するむのとする。

3. 軽油の欄の括弧書きの数值は，消費量の実用範囲を示す。実續がこの範国に入る確率は $80 \%$ とれる。

4. ガソリン, モービール, ギヤー油, ゲリースの実用値は軽油の実用值に準じて約士 3 割の範囲にとり，機械の状態と作業条件によって適 宜加減するとのと寸る。

5.ガソリンの欄の括弧書きの数值は始動ガソリン機関を持たない機種の場合を示す。

\section{3. 労 力歩 掛 り}

この設計々算には学力すなわち運転員呿よび運転助手についても，1時間当りの学力歩掛りを算出して秐く必 要がある。それは1日の運転時間の長短によつて 1 時 間当りの労力歩掛りが変るからである。

運転員は普通機械 1 台飞ついて 1 名, 運転助手は機 械 1 台または数台について1名を考觉られるので，そ れぞれの運転 1 時間当りの運転員等の学力歩掛りほ表 -5.3のと括りとなる。乙の他修理工招よび補助人 夫も同様汇扱う。

\section{4. 工費の算定}

ブルドーザ土工に直接関係のある工費についてその 算定法を説明する。

\subsection{1. 運䎐時間に比例して增減する経費}

\section{表一5.3 運転員および助手等の 1 時間当り歩掛り表}

\begin{tabular}{|c|c|c|c|c|c|}
\hline \multirow{2}{*}{$\begin{array}{c}1 \text { 日平均 } \\
\text { 運転時間 }\end{array}$} & \multicolumn{2}{|c|}{ 助手または修理工 } & \multirow{2}{*}{$\begin{array}{l}\text { 運転 員 } \\
1 \text { 台に } 1 \text { 人 }\end{array}$} & \multicolumn{2}{|c|}{ 補 助人 夫 } \\
\hline & 3 台に 1 人 & 2 台に 1 人 & & 1 台に 2 人 & 1 台汇 5 人 \\
\hline 3 & 0.111 & 0.167 & 0.333 & 0.666 & 1.666 \\
\hline 4 & 0.083 & 0.125 & 0.250 & 0.500 & 1.250 \\
\hline 5 & 0.067 & 0.100 & 0.200 & $0 . \mathrm{An} \Omega$ & 1.000 \\
\hline 6 & 0.055 & 0.083 & 0.166 & 0.333 & 0.830 \\
\hline 7 & 0.048 & 0.072 & 0.143 & 0.286 & 0.715 \\
\hline 8 & 0.042 & 0.063 & 0.125 & 0.250 & 0.625 \\
\hline 9 & $(0.042)$ & $(0.063)$ & $(0.125)$ & $(0.250)$ & $(0.625)$ \\
\hline
\end{tabular}

(注) 1. 運転員と助手だけの歩掛り合計の夷績は $0.15 \sim 0.50$ の範团に ある。

2. 1 日平均運転時間 9 洔間以上は残業となるので歩增しの関係上 括弧青きとした。

\section{(1) 運転 経 費}

5.2. 拉よび5.3. 亿説明した方法飞より 1 時間当りの燃料, 油脂等の消費量, 学力歩掛り拉よびその他の材料す なわちケーブル，フィルターエレメント，カッティングエッジ等の消費量を求め，これにとれぞれの単価を掛け る。

\section{(2) 機械償却費}

自己保有の機械で工事をするときは，機械償却費として計算されるが，貸与機械の場合は定期整備を含めたも のを使用料とする場合るある。

使用料を理論的に計算する場合は 4.6. 亿説明した方法により求める現実には貸与会社が定めている 1 時間当り 


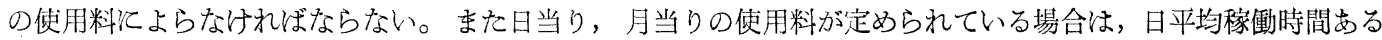
いは月平均稼衔時間で除したものを用いねばならない。

機械償却費算定する場合々基本式としては (3.8) 式を使用する。また表一4.18 招よび表一4.19より求めた 使用料より表一 4.23 より求めて修理費を引いて求めることもできる。

(3) 機械修理費

機械修理費は定期整備費と現場小修理に分けて考兄る。時間当り現場小修理費は定期整储費の 1 2 制が実績と なつているが，本研究の計算資料に扮いては1割として計算した。

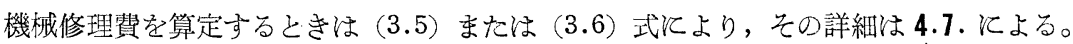

\subsection{2. 固定的な経費（運転時間に無関係な経費）}

\section{(1) 仮 設 費}

工事全体を考觉て現場詰所，機械置場，修理設備，合宿所，等の必要経費を算定する。

(2) 輸 送 費

工事全期間にわたつて，機械の現場への往復の輸送費を算定する。

(3) そ の 他

測量費，借地費，現場諸経費等について算定する。

\subsection{3. 総工費刀算定}

1 時間当り経費

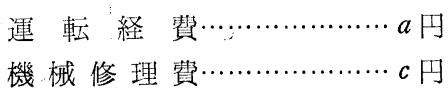

固 定 経 費

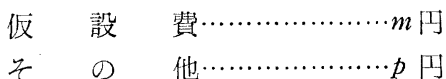

機械償却 費……………... $b$ 円

との他諸経費………………d 円

翰、送費………………n $n$ 円

管理費の百分率…………….... $\%$ （普通は 15 25\%)

とすると

$$
\text { 総工費 }=\left\{(a+b+c+d) \times\left(\frac{\text { 総士 士 量 }}{1 \text { 時間の土工量 }}\right)+m+n+p\right\}\left(1+\frac{R}{100}\right) \cdots
$$

\section{5. 工期の算 定}

計画土工量を完成すると必要な延日数，すなわ台工期は次の関係式沉より求わられる。

$$
\text { 工期 }=\frac{\text { 総 } \pm \text { 工 量 }}{1 \text { 時間の土工量 }} \times \frac{1}{1 \text { 日平均稼衝時間 }} \times \frac{1}{\text { 稼働日数率 }}
$$

注 1. 工期内江定期整備が入るときはをの定期整借日数を加える。

2. 1 日平均稼働時間は実績によれば 1 交替制で $5 \sim 11$ 時間であり， 2 替交制で 12 16 時間である。

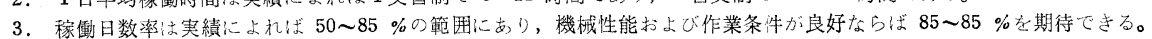

\section{6. ブルドーザ土エと人カトロ運搬土エとの比較}

土工々事のみならず建設工事格いては，ぞの程度施工を機械化することが 経済的であるかということが問題 となる。この問題は難問であつて容易に解答できない。それは機械化施工することにより，早くでき上がること そよる時間的な経済性と，ょくでき上がることによる構造物の耐久性，安全性があたらす，経济性をこの計算に 入れないで工費だけを検討することはできないからである。またある定まつた一つの工事についてその施工方式 を考光て，最も安くでき上がる方式が定まり，先れ使用する機械が決つても，それらの機械を十分嫁働させ るだけの諸条件が満たされなくては安い工事なできない。

次にブルドーザ土工と人カトロ運搬土工について両者の具体的な工費について比較する。

工事は $50 \mathrm{~m}$ の運搬を伴う道路土工で作業条件はごく標準的な場合とする。

いま小松 D-50 型ブルドーザ（昭和 28 年度製）で土運搬作業をする場合，運搬距離 $30 \mathrm{~m}$ 飞怙ける平均作業能力 は，道路土工の場合を考光て，表一2.4 そより，

作業条件のよい場合 $(F=1.0) \cdots \cdots \cdots \cdots \cdots \cdots \cdots . . .6 \mathrm{~m}^{3} / \mathrm{h}$ (掘りゆるめた土量)

作業条件がやや悪い場合 $(F=0.8) \cdots \cdots \cdots \cdots \cdots . \cdots \cdots \mathrm{m}^{3} / \mathrm{h}("$ " $)$

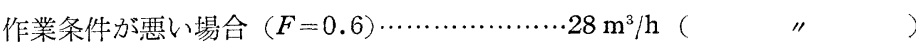

である。 
一方これを人力積込み，トロ運搬で作業する場合たとえば $0.3 \mathrm{~m}^{3}$ 積トロ 4 台，人夫 10 人で行うとすると， 1 特間当りの作業能力は約 $8 \mathrm{~m}^{3}$ である。

作業に要する経費々いずれの場合に扔いても作業時間に比例する要素と，これとは無関係にかかつてくる部分 上と分けて比較する。

(1) ブルドーザ土工の場合

A 作業時間に比例する経費

a. 運転 経 費

・然料, 油脂, その他（表一 5.2 参照）

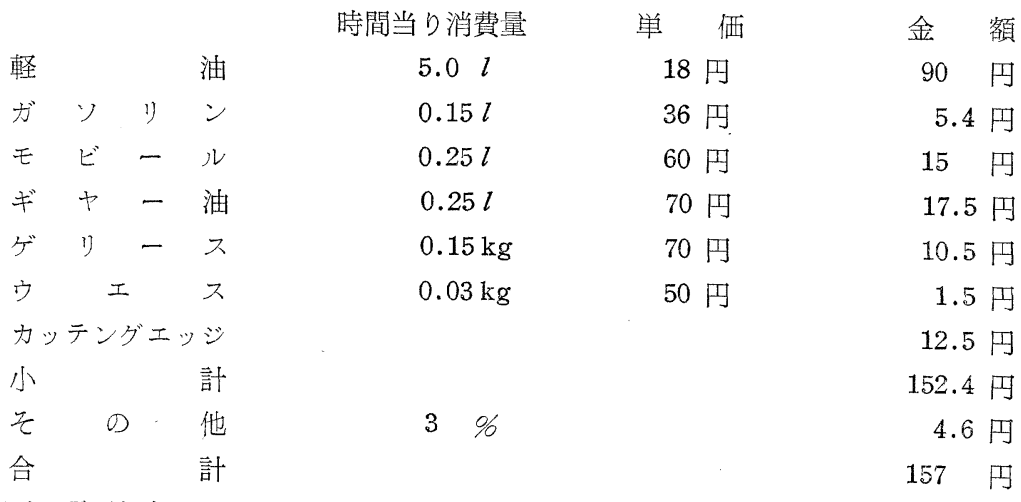

。運転員給与.
運転員
1 名
(@) 1,000 円/日

1 日 6 時間運転とすると表一 5.3 より 1 時間当り

$$
1,000 \times 0.166=166 \text { 円 }
$$

運軽経費合計

$157+166=323$ 円

b. 機械使用料

$$
\text { 表一4.16 とより 1,505 円. }
$$

c. その他諸経費

$$
\text { (a) }+ \text { (b) の約 } 8 \% 146 \text { 円 }
$$

$$
\text { 従つて (a) }+(\text { b })+(c)=323+1,505+146=1,974 \text { 円 }
$$

B 固定的な経費

a. 仮 設 費

詰所，機械格納庫，油庫と乙て合計 8 坪

$$
\text { 坪当り } 10,000 \text { 円 } 80,000 \text { 円 }
$$

b. 機械輸送費

$$
\text { 卜レーラ 1台 } 2 \text { 日 } 30,000 \text { 円 }
$$

c. その他諸経費

$$
\text { (a) }+(\text { b) の約 } 5 \% \quad 5,500 \text { 円. }
$$

従つて $(m)+(n)+(p)=115,500$ 円

(5.1) 式を用いて総土工量と能率の変化汇応でた立 方米当り単佂を計算すると表一5.4 のと物り。ただし 管理費 $8 \%$ とする。

\section{（2）人力卜口運搬土工の場合}

A 作業時間の比例する経費

a. 運転 経 費

・車軸油その他

表一5.4 ブルドーザ D-50による土工の 立方米当り単位 (円)

•土工 夫 10 人 $@ 400$ 月/日

1 日拘束 7 時間労働とすると表一5.3 亿準じて

$400 \times 0.143 \times 10=572$ 円 
運転経費合計

$572+10=582$ 円

b. 機械使用料

レール，木製トロ $0.3 \mathrm{~m}^{3} ， 4$ 台捈よび土工具……1 15 円

c. 現場小修理費

d. その他諸経費

(a) $+($ b $)+($ c) の約 $12 \%$

72 円

従つて (a) $+($ b $)+(c)+(d)=582+15+5+72=674$ 円

B 固定的な経費

a. 仮設 費

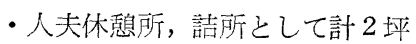

坪当り 6,000 円 12,000 円

・線路敷設招よび跡片付

4,000 円

仮設費合計

$12,000+4,000=16,000$ 円

b. 機 械輸送費

トラック 1台 2 日

c. その他諸経費

諸経費 $(m)+(n)$ の約 $5 \%$ 1,300円

従つて $(m)+(n)+(p)=16,000+10,000+1,300=27,300$

総土工量の変化沉応じた立方米当り単価を計算する

と表一5.5のと抬り。ただし管理費は $12 \%$ とする。

表一5.4 と表一 5.5 のブルドーザ土工と人力積远卜

口運搬土工の雨者を比較すると図一5.1のと祘り。

表一5.5人力皘込トロ運搬土工の立方米当り単価(円)

\begin{tabular}{|c|c|c|c|c|c|}
\hline 総 $\underbrace{}_{\left(\mathrm{m}^{\left.\frac{1}{3}\right)}\right.}$ 量 & 1.000 & 3,000 & 5,000 & 1,000 & 20,000 \\
\hline 単 & 102 & 93 & 90 & 87 & 86 \\
\hline
\end{tabular}

図一5.1でわかると括り総土工量が少なく工事規模が小さ くなると人力, 積込卜口運搬土工の方が単価が安くなる。す なわらブルドーザ土工と比較し $28 \mathrm{~m}^{3} / \mathrm{h}$ とは $a$ 点 (約 1,300 $\mathrm{m}^{3}$ ) で, $37 \mathrm{~m}^{3} / \mathrm{h}$ とね $b$ 点 (約 $2,200 \mathrm{~m}^{3}$ ) で $46 \mathrm{~m}^{3} / \mathrm{h}$ と注 $c$ 点で (約 $5,000 \mathrm{~m}^{3}$ ) で単価が等しくなり, それ以下の総 土工量のときほ人力積込みト口運搬土工が安くなる。

\section{7. 土工単価図表}

本研究による成果の一つの特徴として,ブルドーザによる 土工に标いては, 現場の作業条件の差異により, 作業能率が 大きく変化し，土工単価仅及注す影響がきわめて大きい。

土工単価を算定することほ各種の作業条件が影響しまたと の特の物価の変動も考慮しなければならないので, その算定 にあたつては, 多くの仮定条件を用いなければならない。し かし機械の型式, 現場作業の難易性, 土運般距離の変化に対

図-5.3

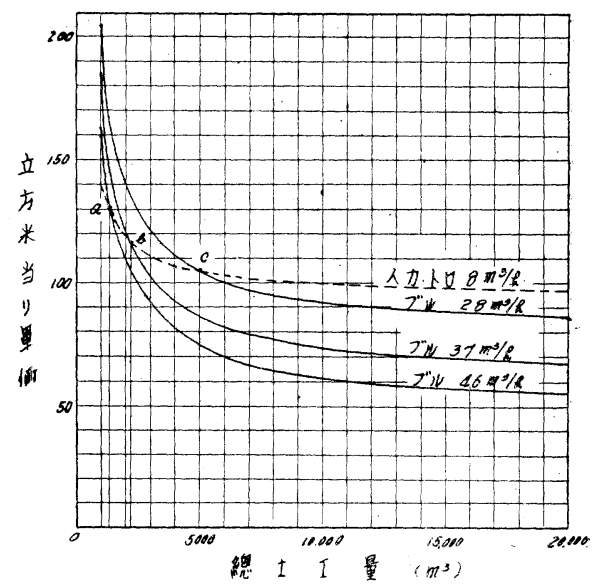

し土工単価がぞのようと変化するものか標準状態近い条件招いて計算したのが次に示するのである。

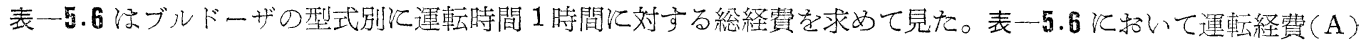

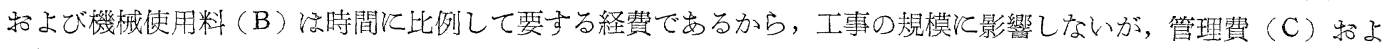

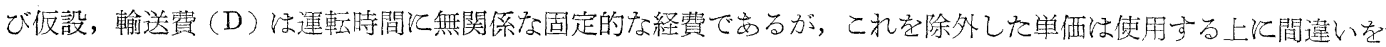
起しやすいので，本表て計上した。これらの経費は比較的土工の規模が小さい場合を想定してのものである。ま た本表はあくまで標準状態を条件としているので, 作業条件がわるくなれ経費はかさむととを忘れてなならない し，また，物価が変れば本表は作成しな特される性質のものである。

表一5.7 表一5.14 はブルドーザの型式別の現場作業係数招よび土運般距離の変化に応じた土工単佂表で, 土量 ほほぐした土1立方米注対するすである。

また表一2.9〜2.17の1 時間当り土工量と表一5.7〜表一5.11の土工単価を組合わせてグラフそしたのが図一 
5.4〜図一5.11 である。な特 1 時間当り土工単佂にほ仮設費特よび輸送費の含るれていないるのを使用している。 表一5.6 ブルドーザ 1 時間当経費内訳表

\begin{tabular}{|c|c|c|c|c|c|c|c|c|c|c|c|c|c|c|c|c|c|}
\hline \multirow{2}{*}{ 項 } & \multirow{2}{*}{ 単 } & \multicolumn{2}{|c|}{ 小松 D-50 } & \multicolumn{2}{|c|}{ 三荾 B B V } & \multicolumn{2}{|c|}{ 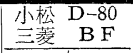 } & \multicolumn{2}{|c|}{$\begin{array}{l}\text { 日 特 } \\
\text { NTK-4 }\end{array}$} & \multicolumn{2}{|c|}{$\begin{array}{l}\text { 日 } \\
\text { NTK-7 }\end{array}$} & \multicolumn{2}{|c|}{ 小松D-120 } & \multicolumn{2}{|c|}{$\begin{array}{c}\text { キャタピラ } \\
\mathrm{D}-7\end{array}$} & \multicolumn{2}{|c|}{ 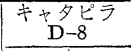 } \\
\hline & & 消費量| & 金額 & 消費量 & 金額 & 消費量 & 金額 & |消費量| & 金額 & 消費量 & 金額 & 消費揑 & 金額 & 消費量 & 金額 & 消費量| & 金額 \\
\hline 渾転経費 (A) & & \multicolumn{2}{|c|}{310} & \multicolumn{2}{|c|}{365} & \multicolumn{2}{|c|}{440} & \multicolumn{2}{|c|}{280} & \multicolumn{2}{|c|}{396} & \multicolumn{2}{|c|}{560} & \multirow{2}{*}{\multicolumn{2}{|c|}{332}} & \multirow{2}{*}{\multicolumn{2}{|c|}{375}} \\
\hline 然料油脂乙の他 & & & 144 & & 199 & & 274 & & 114 & & 230 & \multirow[b]{2}{*}{15.0} & 394 & & & & \\
\hline 軽 & 18 円 $/ l$ & 5.0 & 90.0 & 7.0 & \multicolumn{2}{|c|}{126.010 .0} & 180.0 & 4.0 & 72.0 & 8.5 & 153.0 & & 270.0 & \multirow{2}{*}{$\begin{array}{l}12.5 \\
0.25\end{array}$} & \multicolumn{2}{|c|}{225.014 .0} & 252.0 \\
\hline $\begin{array}{llll}H & ソ & \text { ソ }\end{array}$ & $36 "$ & 0.15 & 5.4 & 0.01 & 0.4 & 0.20 & 7.2 & 0.01 & 0.4 & 0.01 & 0.4 & 0.30 & 10.8 & & 9.0 & 0.30 & 10.8 \\
\hline 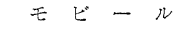 & $60 "$ & 0.25 & 15.0 & 0.35 & 21.0 & 0.50 & 30.0 & 0.20 & 12.0 & 0.40 & 24.0 & 0.70 & 42.0 & 0.60 & 36.0 & 0.70 & 42.0 \\
\hline$\neq \uparrow-$ 油 & $70 "$ & 0.25 & 17.5 & 0.30 & 21.0 & 0.30 & 21.0 & 0.20 & 14.0 & 0.30 & 21.0 & 0.40 & 28.0 & 0.35 & 24.5 & 0.40 & 28.0 \\
\hline ダリース & 70 円/kg & 0.15 & 10.5 & 0.15 & 10.5 & 0.20 & 14.0 & 0.15 & 10.5 & 0.15 & 10.5 & 0.25 & 17.5 & 0.20 & 14.0 & 0.25 & 17.5 \\
\hline ウ $工$ & $50 "$ & 0.03 & 1.5 & 0.03 & 1.5 & 0.03 & 1.5 & 0.03 & 1.5 & 0.03 & 1.5 & 0.03 & 1.5 & 0.03 & 1.5 & 0.03 & 1.5 \\
\hline ケーブル & 250 円/m & - & - & 0.05 & 12.5 & 0.05 & 12.5 & - & - & 0.05 & 12.5 & 0.05 & 12.5 & 0.05 & 12.5 & 0.05 & 12.5 \\
\hline 小計 & & & 139.9 & & 192.9 & & 266.2 & & 110.4 & & 222.9 & & 382.3 & & 322.5 & & 364.3 \\
\hline z $\quad$ 他 & & $\begin{array}{c}\text { 上記の } \\
3 \%\end{array}$ & 4.1 & & 6.1 & & 7.8 & & 3.6 & & 7.1 & & 11.7 & & 9.5 & & 10.7 \\
\hline 運転員給与 & 1,000円/人 & 0.166 & 166 & 0.166 & 166 & 0.166 & 166 & 0.166 & 166 & 0.166 & 166 & 0.166 & 166 & 0.166 & 166 & 0.166 & 166 \\
\hline 譏械使用料（B） & & 1,5 & & 1,7 & & 2,3 & & 1,8 & & 1,98 & & 3,3 & & 2,8 & & 3,4 & \\
\hline 償 却 費 & & & 1,505 & & 1,777 & & 2,374 & & 1,881 & & 1,985 & & 3,312 & & 2,832 & & 3,438 \\
\hline 修＼cjkstart理 & & & & & & & & & & & & & & & & & \\
\hline 管 理 費 (C) & $\begin{array}{c}(\mathrm{A})+(\mathrm{B}) の \\
8 \%\end{array}$ & & 45 & & 71 & & 25 & 1 & 73 & 15 & 91 & & 10 & & 53 & & 18 \\
\hline 小計 $(\mathrm{A}+\mathrm{B}+\mathrm{C})$ & & 1,9 & & 2,3 & & 3,0 & & 2,3 & & 2,5 & & 4,1 & & 3,4 & & 4,2 & \\
\hline 份設，翰送費（D） & $\begin{array}{c}(\mathrm{A}+\mathrm{B}+\mathrm{C}) \\
95 \%\end{array}$ & & 00 & & 17 & & 51 & & 16 & & 28 & & 08 & & 73 & & 13 \\
\hline 計 $(\mathrm{A}+$ & D) & 2,0 & & 2,4 & & 3,1 & & 2,4 & & 2,7 & & 4,3 & & 3,5 & & 4,5 & \\
\hline
\end{tabular}

表一5.7 D-8 ブルドーザ土工単価表（円） $(4,297 \mathrm{~F} / \mathrm{h})$

\begin{tabular}{c||r|r|r|r|r|r}
\hline $\begin{array}{c}\text { 土運搬距離 } \\
(\mathbf{m})\end{array}$ & \multicolumn{7}{|c|}{ 現 } & \multicolumn{1}{|c|}{ 場 作 } & 業 係 \\
\cline { 2 - 6 } & 1.4 & 1.2 & 1.0 & 0.8 & 0.6 & 0.4 \\
\hline 10 & 18 & 20 & 25 & 31 & 37 & 61 \\
20 & 28 & 33 & 39 & 49 & 65 & 98 \\
30 & 39 & 45 & 54 & 68 & 89 & 134 \\
40 & 49 & 57 & 68 & 86 & 113 & 172 \\
50 & 60 & 69 & 84 & 105 & 139 & 204 \\
60 & 70 & 83 & 98 & 123 & 165 & 239 \\
70 & 81 & 95 & 113 & 143 & 187 & 287 \\
80 & 91 & 107 & 126 & 159 & 215 & 331 \\
90 & 102 & 119 & 143 & 179 & 239 & 358 \\
100 & 113 & 130 & 159 & 195 & 269 & 390 \\
110 & 123 & 143 & 172 & 215 & 287 & 430 \\
120 & 134 & 159 & 187 & 239 & 307 & 478 \\
\hline
\end{tabular}

表一5.9 D-80, BF ブルドーザ土工単価表 (円) (3,039 円/h)

\begin{tabular}{c||r|r|r|r|r|r}
\hline $\begin{array}{c}\text { 土運搬距離 } \\
(\mathrm{m})\end{array}$ & \multicolumn{7}{|c|}{ 現 } & 場 & 作 業 係 数 \\
\cline { 2 - 6 } & 1.4 & 1.2 & 1.0 & 0.8 & 0.6 & 0.4 \\
\hline \multirow{2}{*}{10} & 13 & 15 & 19 & 22 & 30 & 45 \\
20 & 21 & 24 & 29 & 36 & 48 & 72 \\
30 & 28 & 34 & 39 & 49 & 66 & 98 \\
40 & 36 & 42 & 51 & 63 & 84 & 127 \\
50 & 43 & 51 & 61 & 76 & 101 & 152 \\
60 & 51 & 60 & 72 & 89 & 121 & 179 \\
70 & 60 & 69 & 82 & 101 & 138 & 203 \\
80 & 66 & 78 & 92 & 117 & 152 & 234 \\
90 & 74 & 87 & 105 & 132 & 169 & 253 \\
100 & 82 & 95 & 117 & 145 & 190 & 276 \\
110 & 89 & 105 & 127 & 160 & 203 & 304 \\
120 & 98 & 113 & 138 & 179 & 234 & 338 \\
\hline
\end{tabular}

表一5.8 D-7 ブルドーザ土工単価表（円） $(3,417$ 円 $/ \mathrm{h})$

\begin{tabular}{c||r|r|r|r|r|r}
\hline $\begin{array}{c}\text { 土運搬距離 } \\
(\mathrm{m})\end{array}$ & \multicolumn{7}{|c}{ 現 } & 場 作 業 係 数 \\
\hline & 1.4 & 1.2 & 1.0 & 0.8 & 0.6 & 0.4 \\
\hline \multirow{2}{*}{10} & 15 & 18 & 21 & 27 & 36 & 53 \\
20 & 25 & 29 & 35 & 43 & 57 & 85 \\
30 & 34 & 39 & 47 & 59 & 79 & 118 \\
40 & 43 & 50 & 60 & 74 & 100 & 148 \\
50 & 52 & 61 & 73 & 92 & 122 & 180 \\
60 & 61 & 71 & 85 & 107 & 142 & 214 \\
70 & 70 & 81 & 98 & 122 & 163 & 244 \\
80 & 79 & 92 & 110 & 137 & 190 & 285 \\
90 & 88 & 103 & 126 & 155 & 214 & 311 \\
100 & 98 & 114 & 137 & 171 & 228 & 342 \\
110 & 107 & 126 & 148 & 190 & 244 & 380 \\
120 & 118 & 137 & 163 & 201 & 263 & 430 \\
\hline
\end{tabular}

表一5.10 NTK-7ブルドーザ土工単価表(円) $(2,572$ 円 $/ \mathrm{h})$

\begin{tabular}{|c|c|c|c|c|c|c|}
\hline \multirow{2}{*}{$\begin{array}{c}\text { 土運搬距離 } \\
(\mathrm{m})\end{array}$} & \multicolumn{6}{|c|}{ 現 場 作 業 係 数 } \\
\hline & 1.4 & 1.2 & 1.0 & 0.8 & 0.6 & 0.4 \\
\hline 10 & 12 & 14 & 17 & 21 & 28 & 41 \\
\hline 20 & 19 & 22 & 26 & 40 & 44 & 66 \\
\hline 30 & 26 & 30 & 36 & 46 & 61 & 92 \\
\hline 40 & 33 & 39 & 46 & 58 & 78 & 117 \\
\hline 50 & 40 & 47 & 56 & 69 & 92 & 143 \\
\hline 60 & 48 & 56 & 66 & 83 & 112 & 160 \\
\hline 70 & 55 & 63 & 76 & 95 & 128 & 183 \\
\hline 80 & 61 & 71 & 86 & 107 & 143 & 214 \\
\hline 90 & 69 & 80 & 95 & 117 & 160 & 234 \\
\hline 100 & 76 & 89 & 107 & 128 & 171 & 257 \\
\hline 110 & 83 & 95 & 117 & 143 & 198 & 285 \\
\hline 120 & 89 & 107 & 128 & 160 & 214 & 321 \\
\hline
\end{tabular}


表一5.11 BBIV ブルドーザ土工峃佂表（円）

$(2,313$ 円/h)

\begin{tabular}{c||r|r|r|r|r|r}
\hline \begin{tabular}{c|} 
土運搬距離 \\
$(\mathrm{m})$
\end{tabular} & \multicolumn{7}{|c|}{ 現 } & \multicolumn{1}{|c|}{ 場 作業 係 数 } \\
\cline { 2 - 7 } & 1.4 & 1.2 & 1.0 & 0.8 & 0.6 & 0.4 \\
\hline \multirow{2}{*}{10} & 12 & 14 & 16 & 20 & 27 & 41 \\
20 & 19 & 22 & 26 & 33 & 44 & 66 \\
30 & 25 & 30 & 36 & 44 & 59 & 89 \\
40 & 33 & 38 & 45 & 56 & 75 & 110 \\
50 & 40 & 46 & 55 & 68 & 92 & 136 \\
60 & 46 & 55 & 64 & 82 & 110 & 165 \\
70 & 54 & 62 & 75 & 92 & 122 & 193 \\
80 & 61 & 70 & 86 & 105 & 136 & 210 \\
90 & 68 & 80 & 92 & 116 & 154 & 231 \\
100 & 75 & 86 & 105 & 128 & 165 & 257 \\
110 & 82 & 96 & 116 & 144 & 193 & 289 \\
120 & 89 & 105 & 122 & 154 & 210 & 330 \\
\hline
\end{tabular}

表一5.13 NTK-4 ブルドーザ土工単価表(円)

$(2,334 \mathrm{H} / \mathrm{h})$

\begin{tabular}{c||r|r|r|r|r|r}
\hline $\begin{array}{c}\text { 土運搬距離 } \\
(\mathrm{m})\end{array}$ & \multicolumn{7}{|c}{ 現 場 作 業 係 数 } \\
\cline { 3 - 7 } & 1.4 & 1.2 & 1.0 & 0.8 & 0.6 & 0.4 \\
\hline \multirow{2}{*}{10} & 18 & 21 & 26 & 32 & 43 & 65 \\
20 & 30 & 34 & 41 & 52 & 69 & 100 \\
30 & 40 & 48 & 57 & 71 & 93 & 137 \\
40 & 52 & 60 & 73 & 90 & 123 & 180 \\
50 & 63 & 71 & 86 & 111 & 146 & 212 \\
60 & 73 & 86 & 106 & 130 & 167 & 259 \\
70 & 83 & 97 & 117 & 146 & 195 & 292 \\
80 & 97 & 111 & 137 & 167 & 212 & 333 \\
90 & 106 & 1.23 & 156 & 195 & 259 & 360 \\
100 & 117 & 137 & 167 & 212 & 292 & 385 \\
110 & 130 & 156 & 180 & 233 & 306 & 428 \\
120 & 137 & 167 & 195 & 259 & 333 & 467 \\
\hline
\end{tabular}

表一5.12 D-50 ブルドーザ土工単価表(円)

$(1,960$ 円 $/ \mathrm{h})$

\begin{tabular}{|c|c|c|c|c|c|c|}
\hline \multirow{2}{*}{$\begin{array}{l}\text { 土理掤距離 } \\
(\mathrm{m})\end{array}$} & \multicolumn{6}{|c|}{ 現 場 作 粟 係 数 } \\
\hline & 1.4 & 1.2 & 1.0 & 0.8 & 0.6 & 0.4 \\
\hline 10 & 14 & 16 & 19 & 24 & 32 & 48 \\
\hline 20 & 22 & 26 & 31. & 39 & 52 & 78 \\
\hline 30 & 31 & 36 & 43 & 53 & 70 & 109 \\
\hline 40 & 38 & 45 & 54 & 68 & 89 & 131 \\
\hline 50 & 47 & 54 & 65 & 82 & 109 & 163 \\
\hline 60 & 54 & 63 & 78 & 98 & 131 & 196 \\
\hline 70 & 63 & 75 & 89 & 115 & 151 & 218 \\
\hline 80 & 73 & 85 & 98 & 122 & 163 & 245 \\
\hline 90 & 78 & 93 & 109 & 140 & 178 & 280 \\
\hline 100 & 89 & 103 & 122 & 151 & 196 & 324 \\
\hline 110 & 98 & 115 & 140 & 163 & 218 & 362 \\
\hline 120 & 103 & 122 & 151 & 178 & 245 & 392 \\
\hline
\end{tabular}

注：以上の土工単価注現場の仮設備費括よび機械の輸送蕒が含まれていない。

昭和 31 年 10 月 25 日印刷

昭和 31 年 10 月 31 日発行

\section{土木学 会論 文 集 \\ 第 37 号}

脿一5.14 D-120ブルドーナ゙土工単価表（円）

$(4,182$ 円 $/ \mathrm{h})$

\begin{tabular}{|c|c|c|c|c|c|c|}
\hline \multirow{2}{*}{$\begin{array}{c}\text { 土運搬距離 } \\
(\mathrm{m})\end{array}$} & \multicolumn{6}{|c|}{ 現場 作 業 係 数 } \\
\hline & 1.4 & 1.2 & 1.0 & 0.8 & 0.6 & 0.4 \\
\hline 10 & 16 & 19 & 23 & 29 & 39 & 58 \\
\hline 20 & 26 & 30 & 37 & 47 & 62 & 93 \\
\hline 30 & 36 & 42 & 51 & 64 & 85 & 127 \\
\hline 40 & 41 & 53 & 65 & 82 & 107 & 161 \\
\hline 50 & 55 & 64 & 79 & 100 & 131 & 199 \\
\hline 60 & 64 & 76 & 93 & 116 & 155 & 233 \\
\hline 70 & 75 & 87 & 107 & 135 & 174 & 262 \\
\hline 80 & 84 & 97 & 120 & 149 & 199 & 299 \\
\hline 90 & 93 & 110 & 135 & 167 & 220 & 349 \\
\hline 100 & 105 & 120 & 149 & 182 & 246 & 381 \\
\hline 110 & 113 & 131 & 161 & 199 & 279 & 418 \\
\hline 120 & 123 & 144 & 174 & 220 & 299 & 466 \\
\hline
\end{tabular}

著者東京都千代田区丸，内 1 , 1

電源開発株式会社土木部機械課

編集兼発行者＼cjkstart東京都千代田区大手町 2 丁目 4 番地

印刷者東京都港区赤坂溜池 5 番地

印刷所東京都港区赤坂溜池 5 番地
定価120円（干 20円）

伊丹康夫

中 川 - 美

大沼 正吉

株式会社技 報 堂

東点中央郵便局区内 千代田区大手町 2 丁目 4 番地
発行所 社団土 木学 
図一5.4

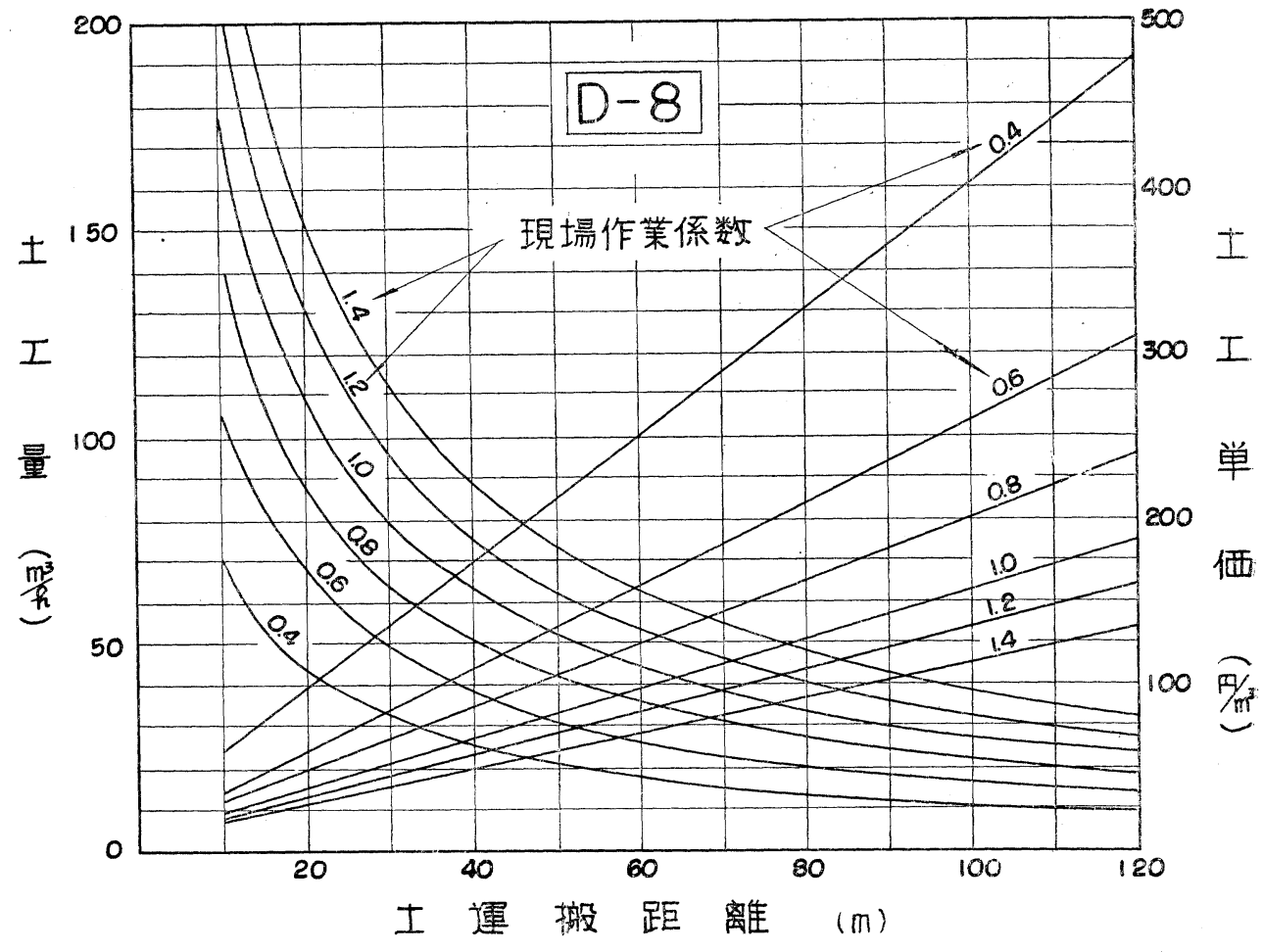

図一 5.5

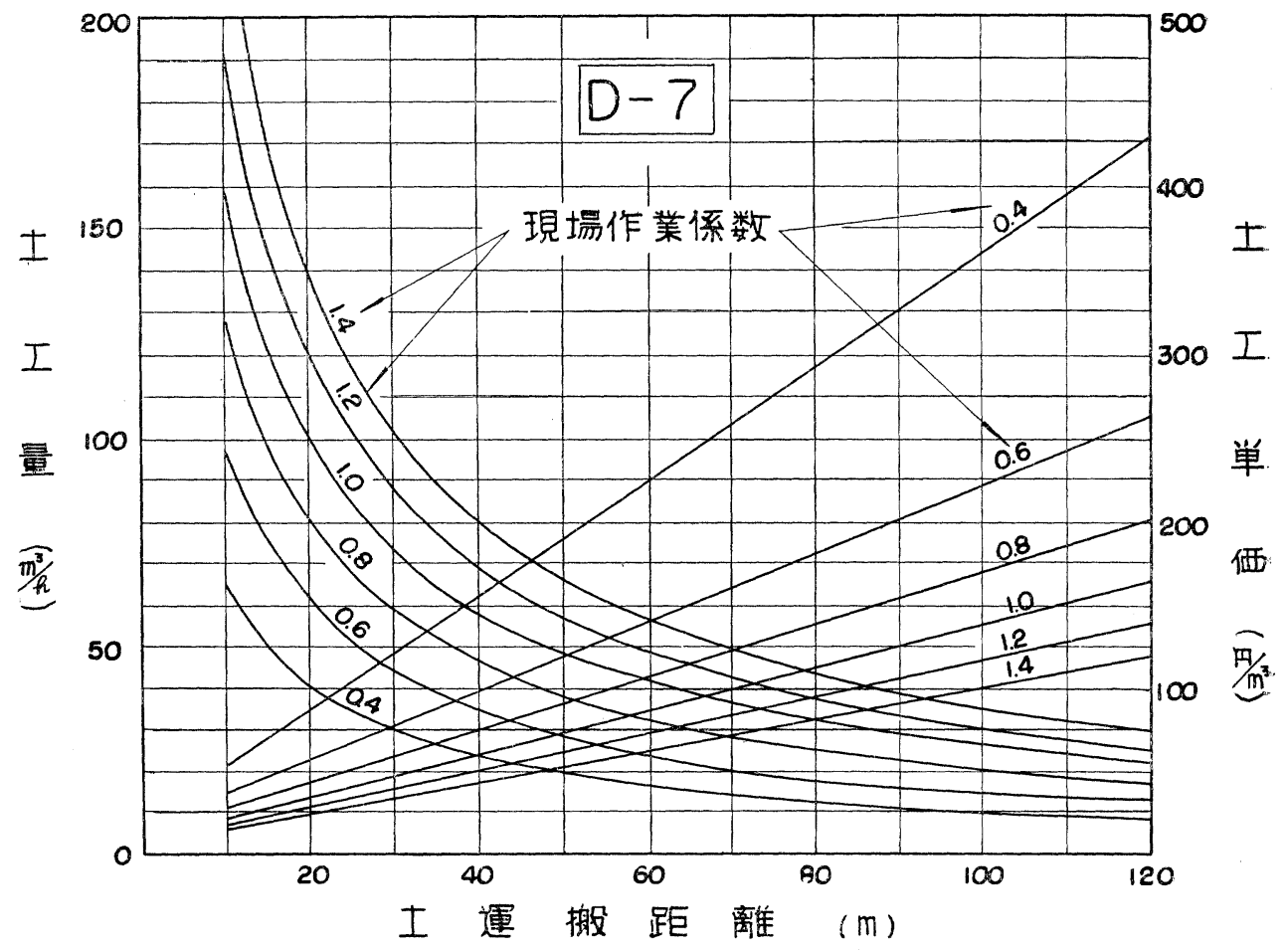




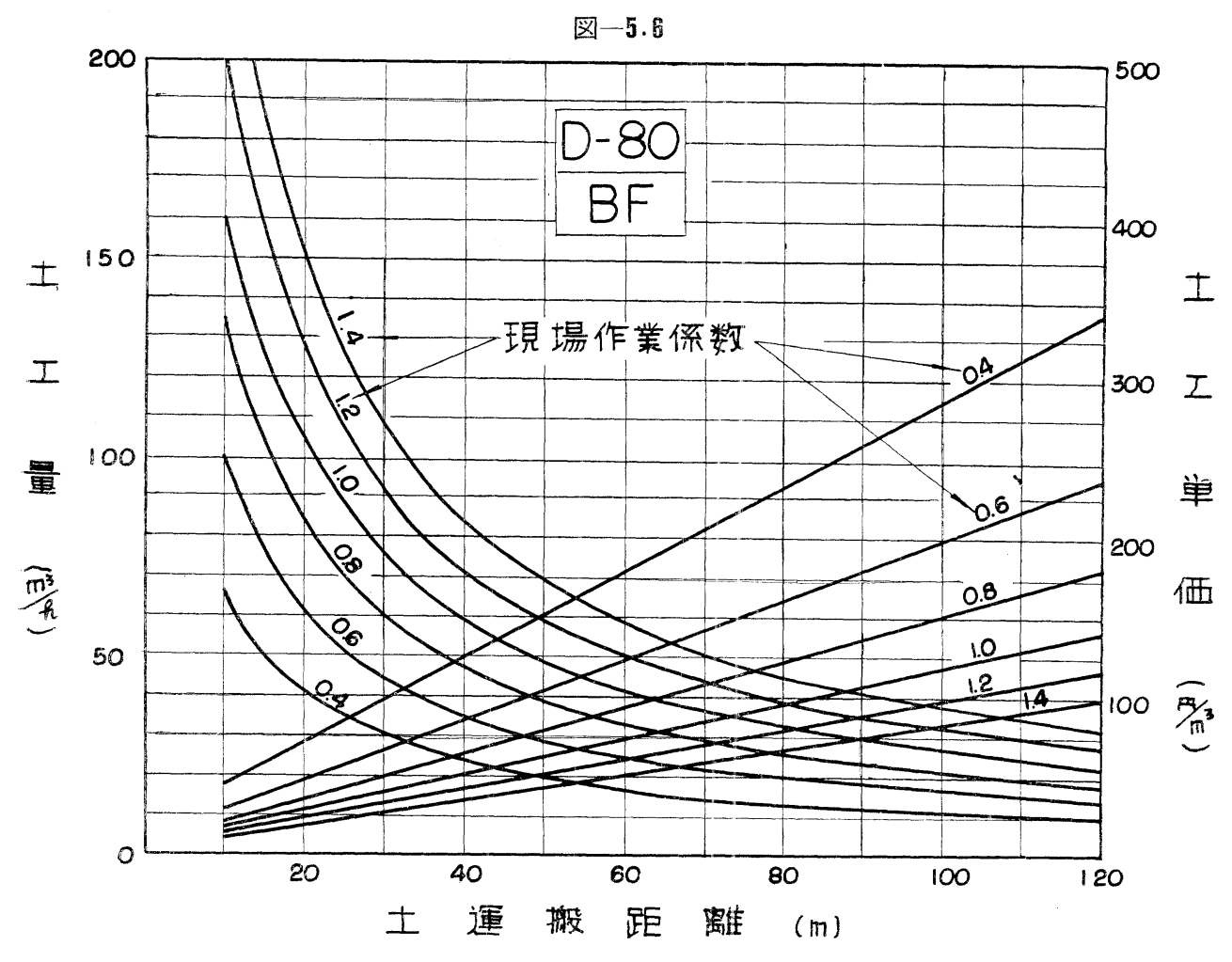

図-5.7

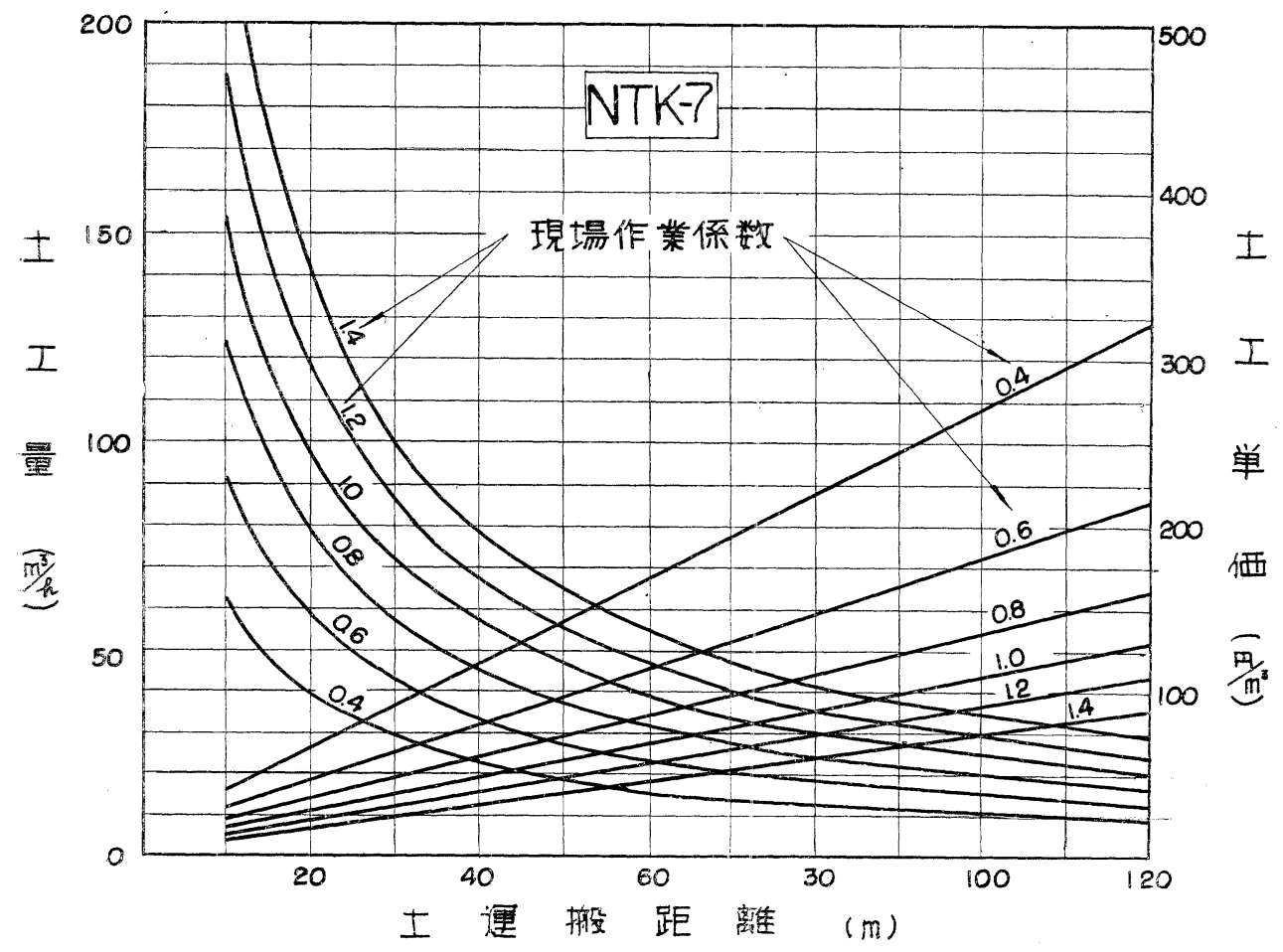


図-5.8

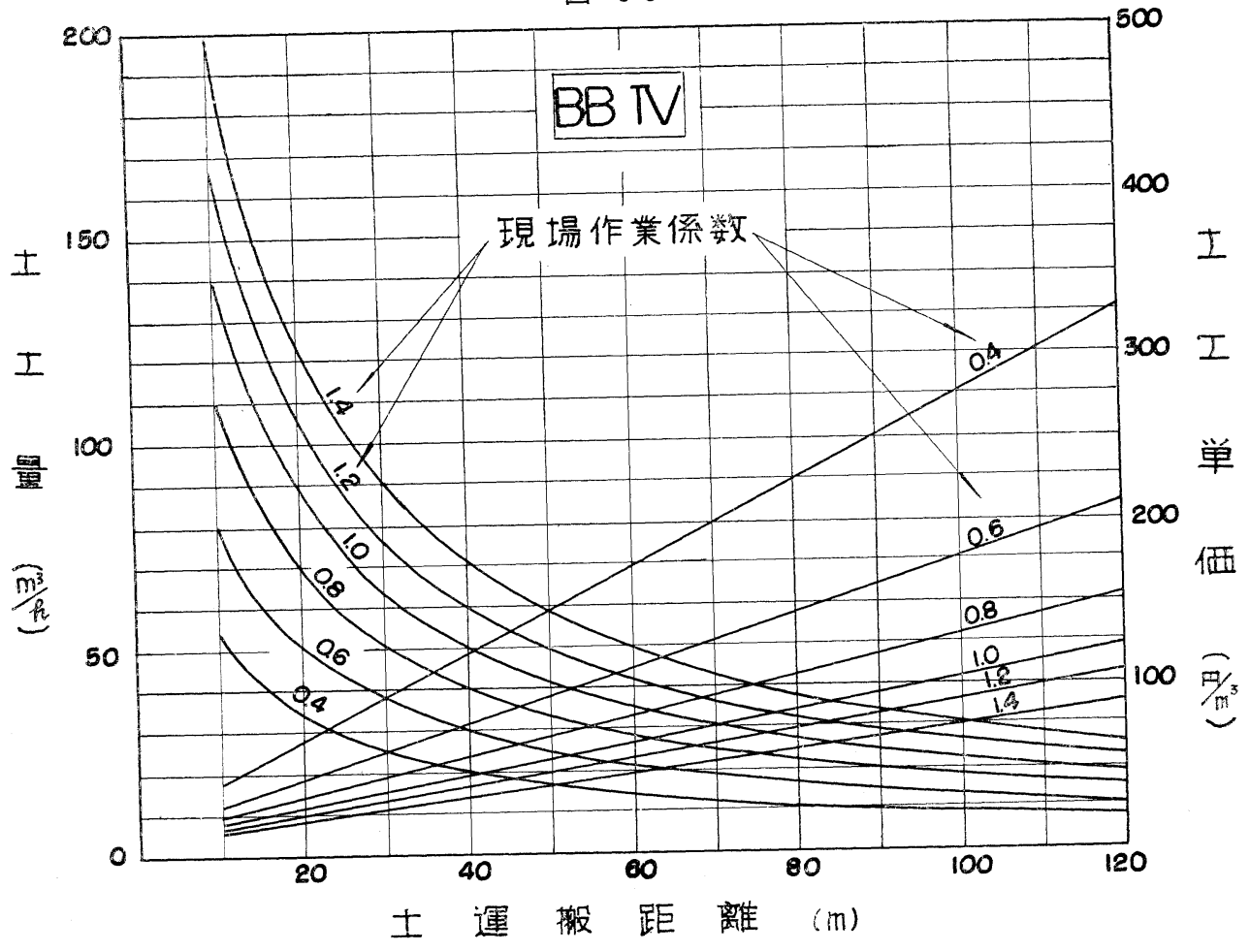

図-5.9

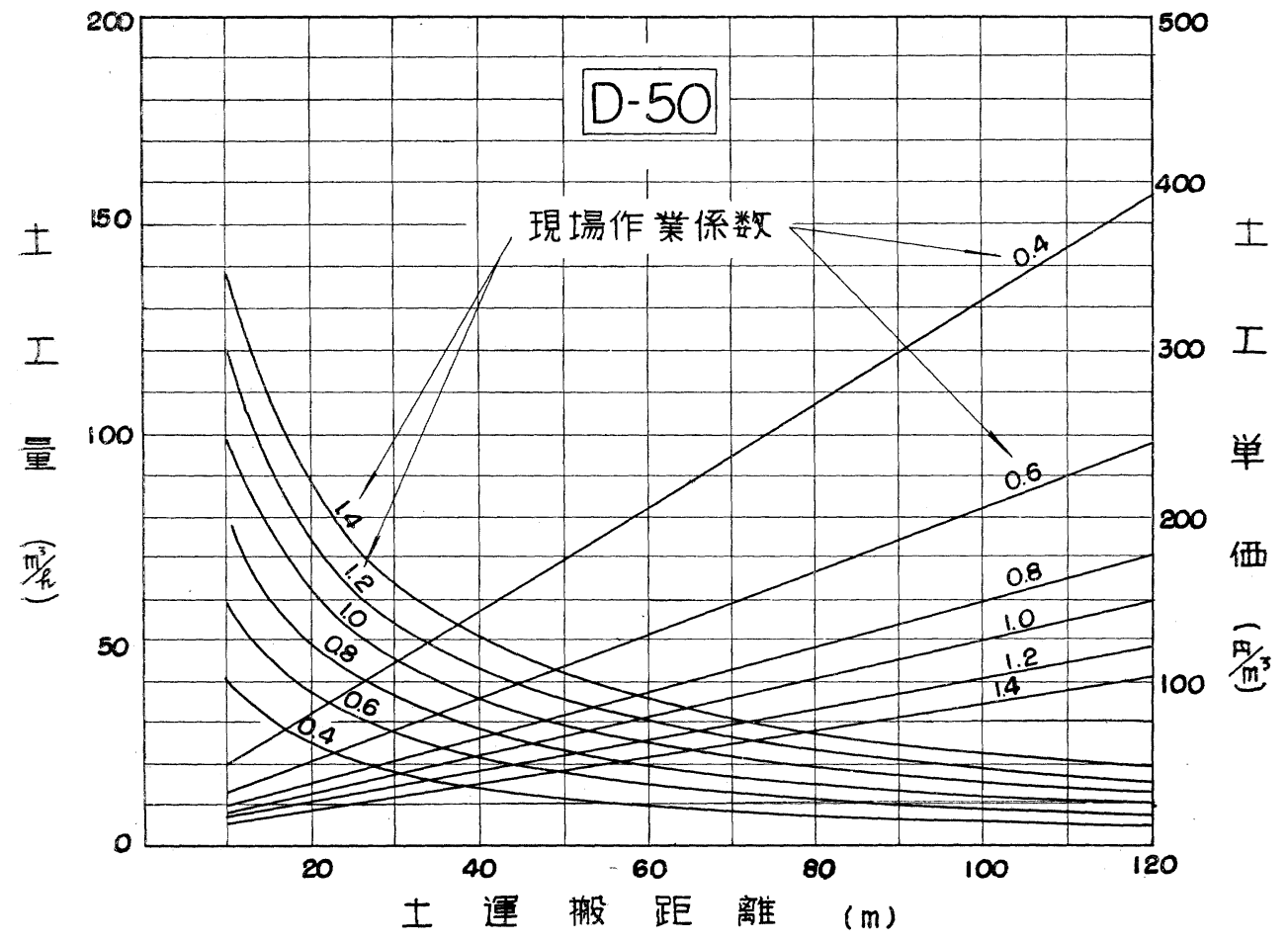




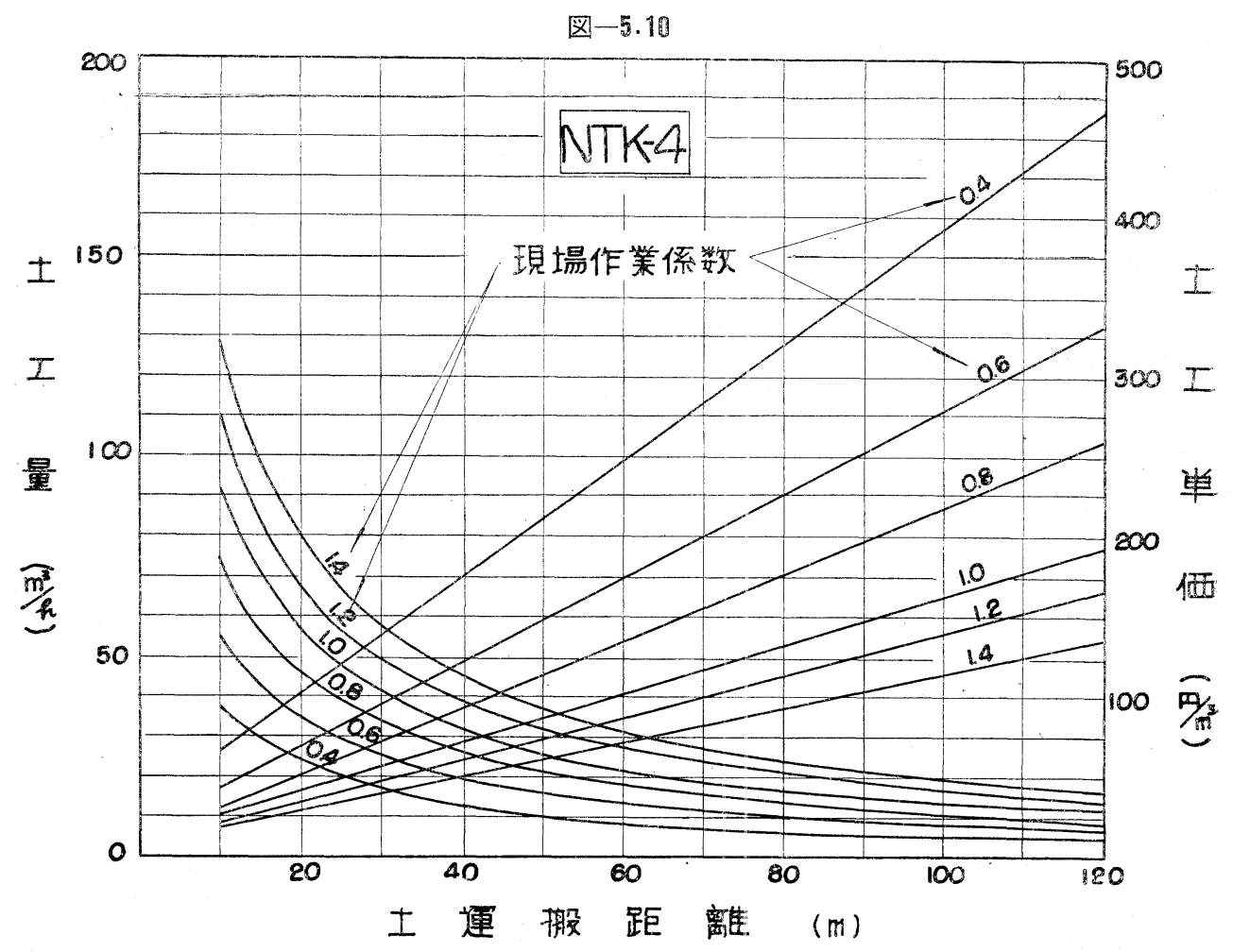

図-5.11

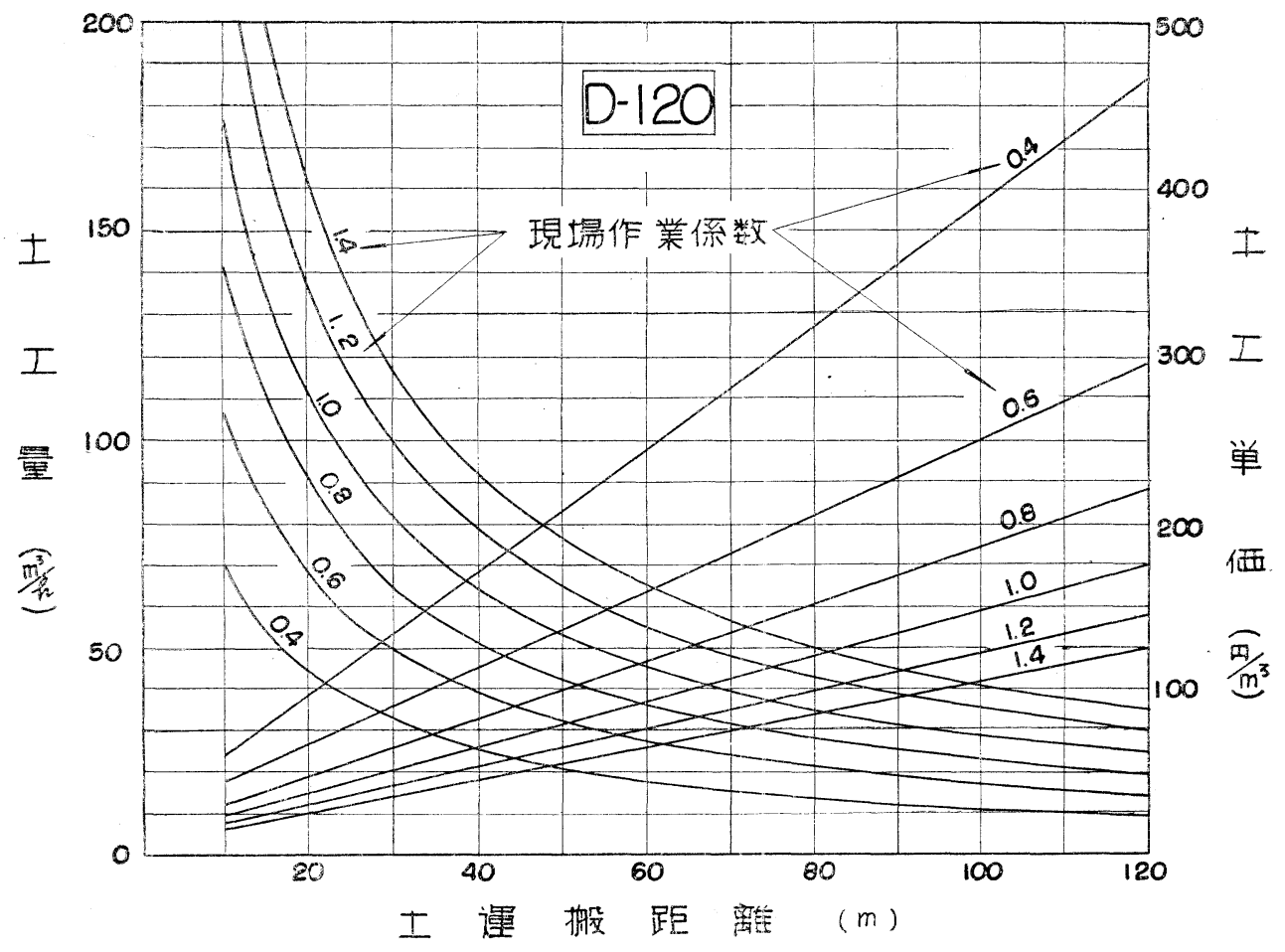

